\title{
KERNDEELING EN SYNAPSIS BIJ SPINACIA OLERACEA L.
}

THEO J. STOMPS 

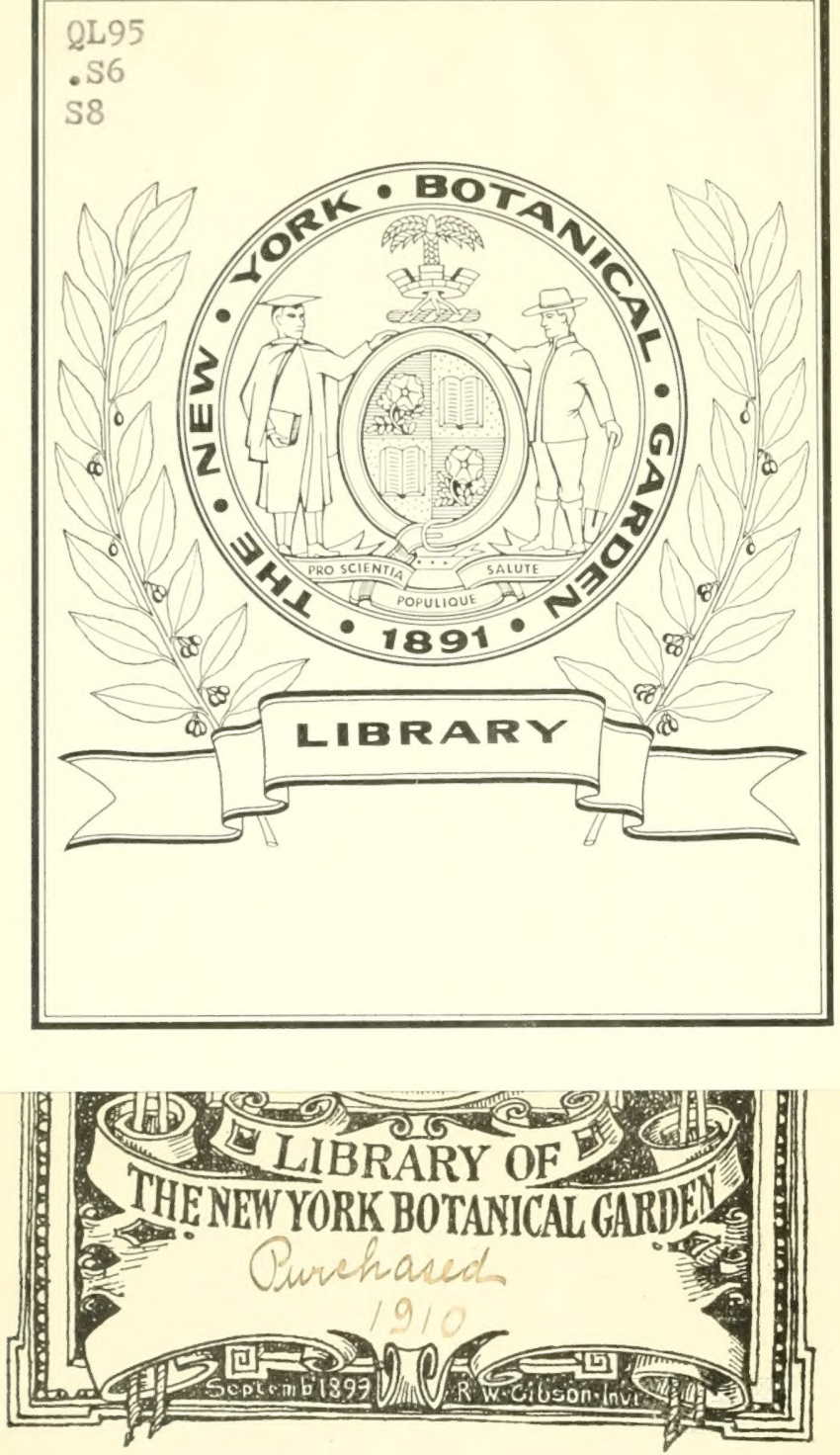




KERNDEELING EN SYNAPSIS

BIJ SPINACIA OLERACEA L. 
GEDRUKT BIJ M. J. PORTIELJE, AMSTERDAM. 


\section{KERNDEELING EN SYNAPSIS BIJ SPINACIA OLERACEA L.}

\section{ACADEMISCH PROEFSCHRIFT}

TER VERKRIJGING VAN DEN GRAAD VAN

\section{Doctor in de Plant- en Dierkunde,}

AAN DE UNIVERSITEIT TE AMSTERDAM

OP GEZAG VAN DEN RECTOR-MAGNIFIOUS

$$
\text { DR. M. STR A U B, }
$$

Hooglegraar in de Faculteit der Geneeskunde,

\section{IN HET OPENBAAR TE VERDEDIGEN}

in de AULA der Universiteit

op Woensdag 18 Mei 1910, des namiddags ten 41/2 ure,

DOOR

\section{THE0D00R JAN STOMPS,}

GEBoren TE AMSTERdaM.

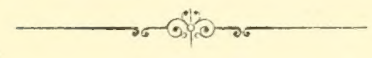

AMSTERDAM - M. J. PORTIELJE - 1910. 
QL95

.56

58

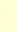


AAN MIJNE MOEDER EN AAN DE NAGEDACHTENIS VAN MIJN VADER. 



\section{VOOR W OORD.}

Gekomen aan het einde van mijn Akademischen studietijd, is het mij eene behoefte, mijn oprechten danh. te betwigen aan allen, die tot mijne wetenschappelijlie vorming hebben bijgedragen.

Met erkentelijkheid, hooggeachte Dr. Costerus, denk ik steeds nog terug aan Uwe lessen, aan de vijze, waarop $U$ mijne liefde voor de studie der levende natuur wist aan te wakkeren en te leiden.

Ook tot $U$, zeer geachte Dr. TERwen, zij het mij veroorloofd, hier een warm woord van dank te richten. Gaarne erken ik, dat voor mij ten minste de studie der Klassieken niet overbodig was, dat ik juist daardoor veel heb geleerd.

Vooral echter voel ik mij gedrongen mijn dank te betuigen aan de Hoogleeraren in de Faculteit der Wisen Natuurkunde, in het bijzonder aan de Professoren Weber, Sluiter, Dubors, Ritzema Bos en de Meyere, voor hun onderwijs en leiding bij mijne studie.

Een afzonderlijk woord van dank zij het mij ieroorloofd te richten tot $U$, hooggeleerde VERschaffelT, 
voor wat it op college en laboratorium van $U$ mocht leeren.

Mijn onderzoek ben it begonnen op aansporing en onder leiding can Geheimrat Prof. Dr. E. Strasburger, die mij bij herhaling op zijn laboratorium te Bonn gastvrijheid verleende.

Het is mij cene behoefte hem daurroor hier openlijl mijn oprechten danl: te betwigen. In het bijzonder echter roor de buitengewone belangstelling, die hij mij bij mijn werl: declachtiy liet worden, en roor de wijze, waarop hij mij steeds den weg wees, moeilijkheden te oremwinnen.

Ten slotte een woord van innigen dank aan $U$, hoogyeleerde DI TRIEs, hooggeachte Promotor, roor de wijze, waarop Gij mij zoowel gedurende mijne studietijd, als rooral bij de voltooïng ian dit proefschrift, met raad en daad hebt bijgestaan en voor het voorrecht de laatste jaren als Uw assistent aan de Amsterdamsche Universiteit werkzaam te hebben mogen zijn. 


\section{N H O U D.}

Bladz.

INLEIDING • • • • • • • • • • • • • • 1

HOOFDSTUK I. MATERIAAL.

§ 1. Variëteiten van Spinacia oleracea L. . . 5

$\$ 2$. Het kweeken van het materiaal . . 7

§3. Beschrijving der bloemen . . . . . 10

$\S$ 4. De ontwikkeling der bloemen . . . . 13

HOOFDSTUK II. Methoden van onderzoeK.

$\S 1$. Het vervaardigen der praeparaten . . 19

§ 2. Technische bijzonderheden. • . . . . 29

HOOFDSTUK III. DE VERMEENDE APOGAMIE van Spinacia.

$\S 1$. Over het verband tusschen apogamie en het aantal der chromosomen . . . . 32

$\S 2$. Komt bij Spinacia apogamie voor? . . 46

$\S 3$. De chromosomen van Oenothera gigas. . 52 HOOFDSTUK IV. Vegetatieve deelingen in SPINACIA OLERACEA.

§ 1. Tweekernige cellen in wortels . . . 65

$\S$ 2. De paring der chromosomen . . . . . 72

$\S 3$. De overlangsche splitsing der chromosomen. . . . . . . . . . . 79 
Bladz.

HOOFDSTUK V. DE REDUCTIE-DEELING BIJ Spinacia oleracea.

\$ 1. Historisch overzicht . . . . . . 85

\$2. Het ontstaan der diakinese-paren bij Spinacia . . . . . . . . . . 95

§ 3. De heterotype en homoiotype deelingen bij Spinacia . . . . . . . . 106

\$ 4. Bespreking der resultaten . . . . . 114 HOOFDSTUK VI. DE ROL DER VACUOLeN BIJ DE KERNDELLINGEN.

\$1. Waarnemingen bij Spinacia oleracea. . 127

§2. Vacuolen in meristematische cellen . . 140

§3. Cytologische argumenten . . . . . . 148

Samenvatting der resultaten . . . . . . 157 Naschrift . . . . . . . . . . . 161 Figurenverklaring . . . . . . . . . . 165 


\section{N L E I D I N G.}

1. IBSRART NEW YUI BOTANILAI (i) KMUR.AS

Nog steeds heerscht verschil van meening over de reductie-deeling, over de wijze, waarop in spore-, pollenen embryozak-moedercellen het aantal chromosomen tot de helft wordt teruggebracht. Een deel der onderzoekers, en zeker wel het grootste gedeelte, meenen, dat bij de voorbereiding tot deze deeling de chromosomen zich twee aan twee naast elkander leggen, dat de aldus ontstane paren gedurende het synapsis-stadium blijven bestaan en, na zich verkort en verdikt te hebben, de chromosomenparen van de kernplat vormen. Anderen echter schrijven het ontstaan van dubbele draden in de prophase toe aan het optreden van de lengtesplitsing, die de chromosomen zouden moeten ondergaan, wanneer de deeling zonder reductie zou plaats hebben. Dit begin van eene lengtesplitsing zou dan echter later weer verdwijnen. Naar hunne opvatting komen uit het synapsis-kluwen geen paren vau naast elkander liggende chromosomen, maar lissen te voorschijn, waarvan de twee beenen ieder een chromosoom zouden vertegenwoordigen. Op nog latere stadiën zouden de beenen dezer lissen zich tegen elkander aanleggen, en daardoor zouden dan de chromosomenparen van de kernplaat gevormd worden. Deze onderzoekers meenen, dat alle 
chromosomen galijkelijk in eene veelvuldig gabogen reeks achter elkimder gerangschikt zijn, zoodat ook do lissen uit twee opeenvolgende chromosomen zouden bestaan. Daarentegen zijn de rortegenwordigers der verstegenoemde meening er van overtuigd, dat in de kernen twee stellen van chromosumen voorkomen, waarvan de componenton twee am twee naast elkander ligwen. En daar men pleegt aan te nemen, dat van deze beide stellen het eene van den vadere en het ander van de moeder geërfd is, is deze kwestie naturulijk van groot gewicht.

Omtrent dit belangrijke punt door eigen waarneming tot eene overtuigne te komen, was anvankelijk het doel van mijn onderzoek. Professor Strasburger had de goedheid, mij er op te wijzen, dat zeer waarschijnlijk Spinacia oleracea $L$. een bij uitstek geschikt materiaal zou leveren, om dit doel te bereiken. Inderdaad is dit gebleken het geval te zijn.

Zooals door Strasburger reeds was medegedeeld ${ }^{\text {)}}$ ) komen in de vegetatieve kernen van deze plant slechts 12 chromosomen voor. Het liet zich aanzien, dat dit geringe auntal voor een onderzoek der reductie-rer'schijnselen gunstig moest zijn. De bloemen van $\mathrm{S} p$ in a $\mathrm{e}$ ia staan in zeer dicht gedrongen infloreseentiën. Maar in het vruchtbeginsel der vrouwelijke blocmen komt slechts één enkele raadknop voor en dit bemorilijkt in hooge mate het onderzoek van de ontwikkeling der embryozakien. Daarom heb ik voor het bestudeeren der synaptische verschijnselen voornamelijk de ontwikkeling ran het stuifmeel gekozen. Deze is darrvor uitnemend geschikt.

1) Zeitpunht der Bestimmung des Geschlechts, Apogamie, Parthenogenesis und Reduktionsteilung. Heft VII der Hist. Beitr. Jena, G. Fischer 1909 , p. 34 . 
Vooreerst zijn de antheren buitengewoon rijk aan stuifmeel, zoodat men zeer talrijke gelijksoortige stadiën in eenzelfde doorsnede kan bestuleeren. Ten tweede zijn de mannelijke bloeiwijzen zou gedrongen, dat men ze in hun geheel met den microtoom kan snijden. In één enkel praeparaat kan men zoodoende doorsneden door jonge en door veel oudere bloemknoppen vereenigd vinden. Daardoor kan men soms alle stadiën der reductiedeeling van de vroegste prophase tot aan de vorming der pollenkorrels in zulk een praeparaat bijeen aantreffen. Een groot voordeel levert verder het verschijnsel op, dat soms onder in eene anthere de moedercellen in een ander stadium verkeeren dan bovenin en dat deze beiden dan door alle overgangen verbonden zijn. Zoo kan men soms boven in eene anthere de spoel der eerste deeling waarnemen, waarbij de chromosomen op weg zijn naar of juist aangekomen zijn bij de polen. Iets lager ziet men, hoe tusschen die chromosomen vacuolen ontstaan en de chromosomen daardoor van elkander gedrongen worden. Nog lager is de kernmembraan gevormd en vindt men de dochterkernen der eerste deeling in rust.

Dank zij deze geschiktheid van het materiaal, was ik in staat iets naders omtrent de prophasen der reductiedeeling waar te nemen. Daarbij zag ik, dat reeds in de vroege prophasen de chromosomen zich parsgewijze naast elkander plaatsen en dat zóó de paren der kernplaat tot stand komen. Dit is in overeenstemming met hetgeen door Strasburger, Grégoire en anderen reeds is beschreven. Ook kon ik waarnemen, dat uit het synapsis-kluwen lissen te voorschijn komen en wel ten getale van 6. In tegenstelling met het beweren van FARMer en zijne aanhangers vermocht ik echter aan te toonen, dat deze lissen niet bestaan uit twee achter 
elkaar geplaatste chromosomen en dat niet elk der beide beenen een chromosoom vertegenwoordigt. Ellie lis is eigenlijk eene dubbelo lis en bestaat uit twee naast elkaar liggende lisvormige chromosomen. In den resel openen deze dubbele lissen zich zóó, dat hun eene cinde uit het synapsis-kluwen vrij komt. Diarbij heeft eene gelijkmatige rerkorting en verdikking van de dubbele draad plaats, tot de afmetingen, welke de paren in de diakinese zullen hebben, bereikt zijn.

Het optreden van paren van chromosomen in de prophase van de reductie-rleeling kan daarmee samenhangen, dat ook in regetatieve kernen de chromosomen in den rusttoestand paarsgewijze naast elkaar liggen. Daarom onderzocht ik in mijne praeparaten eveneens de vegetatieve deelingen en bestudeerde deze ook in worteltoppen. Dit onderzoek bevestigrie het uitgesproken vermoeden.

Behalve de paring der chromosomen trokken in het bijzonder ook de in en tusschen deze voorkomende zoogenoemde alvenlen mijne aandacht. Bij nader onderzoek bleken zij mij echte vacuolen te zijn, geheel overeenkomende met die, welke in meristematische cellen door WeNT zijn ontdekt. Uit praeparaten van $\mathrm{S} p$ in a c i a en van vele andere objecten meen ik te mogen besluiten, dat deze vacuolen in de kernen eene gewichtige rol spelen. Zoo ben ik er ook toe gekomen de kernmembraan als een tonoplast te beschouwen. In het laatste hoofdstuk zal ik de argumenten uiteenzetten, welke er mijns inziens voor pleiten, aan vacuolen eene belangrijke rol bij de kerndeelingen toe te kennen. 


\section{H O OF DSTUK I.}

\section{MATERIAAL.}

\section{§1. Variëteiten van Spinacia oleracea $L$.}

Ten einde voldoende van materiaal voorzien te zijn schafte ik mij zaden aan van negen verschillende variëteiten van spinazie. In den catalogus van J. B. Wijs en Zoon te Amsterdam waren deze aangeduid met de namen: rroeg, rond; vroeg, scherp; Hollandsche ronde Winter-; Amsterdamsche reuzen-, rond; Amsterdamsche reuzen-, scherp; verbazende reuzen-, scherp; Gaudry; Viroflay en Savoysche. Een deel dezer vormen heeft, zooals uit den naam reeds blijkt, ronde ongedoornde vruchten. Tot deze groep behooren ook de variëteiten Gaudry en Viroflay. Bij de anderen komen aan de vrucht twee tot vier doorntjes voor, welke bij het rijpen uit het perigoon zijn ontstaan.

In wetenschappelijke werken vindt men in den regel slechts twee vormen van Spinacia oleracea L. opgegeren. In de eerste plaats het type met doornen aan de rruchten, ook wel genaamd Spinacia oleracea spinosa Moesch. Volgens A. DE CAxdolle stamt deze soort waarschijnlijk uit de Levant. Zij is daar echter nog niet in het wild gevonden, tenzij zij eene gekweekte modificatie is van Spinacia tetrandra Steven, die in het zuidelijk deel 
van den Kaukasus, Turkestan, Perzië en Afghanistan groeit en daar ook als groente wordt gebruikt. 1)

Voloens de CAxDolice bestat er geen noemenswaard verschil tusschen deze wilde soort en de in Europa gekweekte met gedoornde vruchten.

Daartegenover staat dan het type met ongedoornde vruchten, bekend als Spinacia oleracea, $\beta$ L. of Spinacia glabra Niluer of ook als Spinacia oleracea inermis Moench. Deze vorm is waarschijnlijk in de cultuur opgetreden. A. DE CANDOLLE ${ }^{2}$ ) zegt er van:

„l'Epinard de Hollande ou gros Epinard, dont le fruit n'a pas d'épines, est évidemment un produit des jardins. Tragus, soit Bock, en a parlé le premier dans le XVTe siecle".

In zijn Géographie Botanique líaisomnée ${ }^{3}$ ) laat hịj zich eveneens in dezen zin uit:

"Le Spinacia glabra MiLler, me paraît une race produite par la culture. Non seulement personne ne l'a trouvé sauvage, mais encore il n'est mentionné que dans les cultures européennes et semble s'être produit après l'introduction de la plante ordinaire".

Het gedoornde type schijnt minder gevoelig voor koude te zijn dan het ronde. Vandaar dat het als Winterspinazie in den rexel in het najaar wordt gezalid en in het voorjaar gesneden. Het ronde type daarentegen wordt als Zomerspinazie meest in het voorjaar, in April, gezaaid ${ }^{4}$ ).

1) A. DE CANDolLE: l'Origine des plantes cultivées p. 78.

3) 1. C.

3) A. De Candolle, Géographie Botanique Raisonnée, 1855 p. 847.

4) Laxgethat. IIandbuch dev Iandwirtschaftichen Pfanzenkunde. Bd. III, p. 73. 
§ 2. Het kweeken van het materiaal.

Om bij het bestudeeren der vegetatieve deelingen onk worteltoppen te kunnen onderzoeken, zaaide ik in het voorjaar van 1909, in pannen met zaagsel, een deel mijner zaden uit. De schotels werden gedeeltelijk in eene warme kweekkas geplaatst, terwijl de overigen aan de buitentemperatuur blootgesteld bleven. In beide culturen ontstonden normale kiemwortels, die geschikt bleken te zijn roor cytologisch onderzoek. De bij hooger temperatuur sevormile kiemwortels leverlen echter niet zulke goede resultaten op, als de onder gervone omstandigherlen ontstane. De praeparaten er van waren mocilijker te kleuren; men kreeg den indruk, dat de wortels door een te snellen groei geleden hadden. In den afgeloopen winter zaaide ik nog eens een aantal zaden uit en wel in kissen ran verschillende temperaturen, te weten: cene wirme en exne grematigle kweekars en eene Orchideëenkas. Na fixeering bleek dit materiaal echter volkomen waardeloos te zijn, daar de kleuring der praeparaten gehen mishkte en alle celwamlen dik en oprezwollen waren.

Waaraan moest dit worden toegescheren?

Zooals bekend, is, is de ontkieming der zaden in het algemeen afhankelijk van de temperatuur, en wel zoodanig, dat men eene minimum-, optimum- en maximumtemperatuur kan onderscheiden. Ontkieming vindt niet meer plaats bij eene temperatuur, die beneden het minimum ligt of het maximum overschrijdt. Binnen deze grenswarden verloopt de ontkieming sneller, naarmate de temperatuur dichter bij het optimum komt, langzamer, naarmate zij meer tot het minimum of maximum nadert. 
SACHS ${ }^{1}$ ) rond roor het minimum, optimum en maximum van eenige gekweokte planten de volgende getallen:

Minimum. Optimum. Maximum.

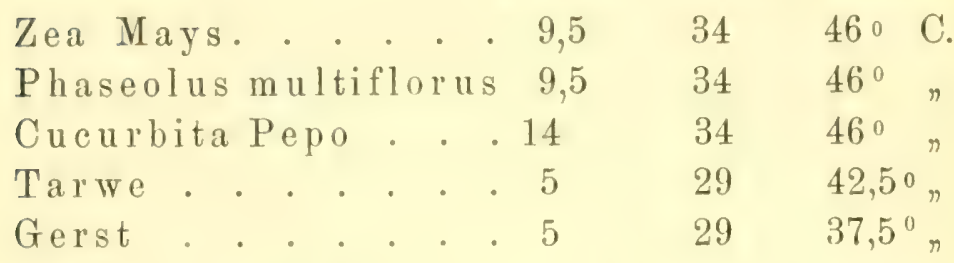

Voor de beide laatste planten schijnt intusschen het minimum nog lager te liggen. Planten, die aan warme streken gewend zijn, vertoonen meest hongere cardinaalpunten der temperatuur, dan die, welke in meer gematigde gewesten te huis behooren. Voor Sin a p is a 1 b a vond DE VRIES ${ }^{2}$ ), dat het optimum bij $27^{\circ}$ en het maximum boven $37^{\circ} \mathrm{C}$. ligt, terwijl de minimumtemperatuur volgens KIRCHNER ${ }^{3}$ ) bij $00 \mathrm{C}$. valt.

Over Spinacia oleracea vind ik slechts in NobBe's Handbuch der Samenliunde (p. 233) eene enkele melledeeling van HABERLANDT ${ }^{4}$ ) opgegeven, warruit blijkt, dat de spinaziezaden beginnen te kiemen bij $4,75^{\circ} \mathrm{C}$. na 9 dagen, bij $10,5^{\circ} \mathrm{C}$. na 5,75 dagen en bij $15,6^{\circ} \mathrm{C}$. en $18,5^{\circ} \mathrm{C}$. na 3,25 dagen. Daaruit is wel geen conclusie te trekken omtrent de cardinaalpunten van Spinacia, maar in overeenkomst met planten uit ons klimaat als tarwe, gerst en mosterd kunnen wij toch aannemen, dat de temperaturen, waarbij de zaden in den winter

1) J. SACHS, Physiologische Untersuchungen ïber die Abhängigkeit der Keimung von der Temperatur. Jahrb. f. wiss. Bot. II. (1860) p. 365.

2) DE VrIES, Matériaux pour la connaissance de l'influence de la température. 1870. Arch. Néerl. Bd. 5, p. 402.

3) O. KIRCHNER, Ueber das Längenvachsthum von Pflanzenorganen bei niederen Temperaturen. Cohn's Beitr. z. Biolog. 1883, III, p. 343.

4) Haberlandt, Landw. Vers.-Stat. XVII, 1874, p. 104. 
in de kassen te kiemen gelegd werden, tusschen het minimum en het optimum lagen en wel veel dichter bij het laatste. $\mathrm{Nu}$ zien planten, die bij optimale temperatuur gegroeid zijn, er in den regel niet anders uit dan die, welke hunne ontwikkeling hebben doorloopen bij temperaturen, die niet te ver boven of beneden dat optimum liggen. Sterke formaticve invloeden worden eerst bemerkbaar, wanneer men tot de grenstemperaturen nadert. Zoo vond Popovici ${ }^{1}$ ), dat, wanneer de ontkieming van zarlen tusschen het optimum en het maximum plaats heeft, met afnemende intensiteit van den grone de lengte der streklkingszone minder wordt. Bij temperaturen dicht bij het minimum heeft juist eene verlenging van die zone plaats. Hieruit mag men dus besluiten, dat eene belangrijke rormverandering bij de spinaziewrortels door de gebruikte temperaturen niet te verwachten was. Zeer zeker waren de temperaturen, waarbij de ontkieming plaats had, hooger dan wanneer de zaden in het voorjaar buiten kiemen. En daar groeiverschijnselen in den regel zóó door hoogere temperaturen beïnvloed worden. dat niet alle factoren op gelijke wijze rersneld worden, konden daarvan kleine afwijkingen het gevolg zijn. Dit blijkt o.a. uit de onderzoekingen ran Hotres ${ }^{2}$ ), die bij hoogere temperaturen minder extranucleaire nucleolen in wortelcellen zag optreden, dan bij lagrere. Een bekend feit is ook, dat eene hoogere temperatuur vaak reel schadelijker werkt, wanneer de lucht rochtig is. Ziarden zullen bijv. in droge

1) Popovicr. Der Einflusz der Vegetationsbedingungen auf die Länge der wachsenden Zone. Bot. Ctrbl. 1900, Bd. 81, No. 2 en 3.

") Geciteerd in StrasBURGER, Ueber Reduktionsteilung, Spindelbildung, Centrosomen und Cilienbildner im Pfunzenreich. Heft VI der HistBeitr. Jena. G. Fischer 1900. 
lucht bij eene bepaalde hooge temperatuur hunne kiemkracht kunnen behouden, terwijl zij die bij dezelfde temperatuur in eene vochtige atmosfeer verliezen. Het is dus niet onmogelijk, dat de verandering van den bouw der cellen en het verschillende kleuringsvermogen toe te schrijven zijn aan de hongere temperatuur in de kassen, in verband met de vochtigheid van de atmosfeer, de verminderde lichtintensiteit, enz.

Hoe dit ook zi.j, uit mijne ervaringen rolgt, dat slechts van zaden, die bij normale, betrekkelijk lage temperaturen gekiemd zijn, een bruikbaar materiaal voor het cytologisch onderzoek mag verwacht worden.

Ten einde gedurende het geheele jaar voldoende materiaal van boemen vow fixatie besehikbar te hebben, zaaide ik reeds vroeg in het voorjaar zaden van alle variëteiten in schotels, die in eene verwarmde kas geplaatst werden. De kiemplantjes werden later op zeer zonnige bedden uitgeplant, walardow een snel doorschieten der bloeistengels wordt bevorderd ${ }^{1}$ ).

Bovendien werden op verschillende tijden van den zomer nieuwe hoeveelheden uitgezaaid. Verschillen tusschen deze culturen beb ik, wat de cytologische verschijnselen aangaat, niet kumnen waarnemen.

In mijne cultuur viel mij het veelvuldig voorkomen van bekervormige bladeren op; een punt, waarop ik elders hoop terug te komen.

\section{§ 3. Beschrijuing der bloemen.}

Ten opzichte van verscheidene punten van de morphologie der bloem bestat nog versehil van opratting.

2) Zie LaNGethaL, Handbuch der landwirtschaftlichen P flunzenkunde Bd. III, p. 73. 
Het kwam mij wenschelijk voor, omtrent deze kwesties door eigen onderzoek tot klaarheid te komen. Met het oog hierop moge eene korte beschrijving van den bouw der bloemen voorafgaan.

Spinacia oleracea L. is dioecisch. Zoowel de mannelijke als de vrouwelijke bloemen staan in dichasiale bloeiwijzen, die tot dichte kluwens zijn samengedrongen. Bij de vrouwelijke planten staan doze meestal in de bladoksels tegen de hoofdas aangedrukt, bij de mannelijke plegen zij tot afgebroken aren vereenigd te zijn.

De mannelijke bloem bestaat uit 4-5 vliezige bloemdekbladeren en evenveel tegenover deze staande meeldraden. Steelblaarjes ${ }^{1}$, ook wel voorbladeren genoemd, worden hier niet aangetroffen. De meeldraden hangen aan hun voet samen, hebben vierhokkige intrors met twee lengtespleten openspringende antheren en stuiven na elkander. Dit laatste rerschijnsel komt bij Chenopodiaceae algemeen voor en wordt door Volkens $\left.{ }^{2}\right)$ aangevoerd als argument tegen de bewering van KIRCHNER, Schulz eil Warmixg, dat bij deze familie windbestuiving eene gronte rol zou spelen. Bij anemophile planten toch plegen de bloemen zich min of meer gelijktijdig te openen en plegen ook de antheren tegelijk te stuiven. Wanneer men daarentegen in den nazomer eene krachtige plant van Chenopodium of Atriplex beziet, zal men vinden, dat van de honderden of zelfs duizenden van bloemen er slechts enkelen goed geopend zijn, terwijl de overigen zich in allerlei andere ontwikkelingsstadiën bevinden. De bloemen openen zich ook niet

1) Oddemans spreekt in het $2 e$ deel van het Leerboek der Plantenkunde door Oudemans en De Vries, Vormleer p. 138 en 179, van steelblaadjes.

$\left.{ }^{2}\right)$ G. Volkens: Chenopodiaceae in Engler en Prantl. Die natïrlichen Pflunzenfamilien III. T. 1. Abt, a. 
plotseling. mar het eene bleemdekblad na het andere buigt zich naar buiten en tegelijk met elk perigoonblad strekt zich de tegenoverstaande meeldraad, om terstond darma open te springen. Hieruit kan ook weer blijken, hoc seschikt de pollenontwikkeling ran $\mathrm{S} p$ in a c i a voor het hestudeeren der reductieverschijnselen moet zijn. Want wegens den ongelijken ouderdom der stuifmeelhokjes main men verwachten op doorsneden door één enkele bloem in de verschillende antheren steeds weer andere stadiën aan te treffen.

De vrouwelijke bloem bestaat slechts uit één vruchtbecrinsel. dat 2 tot 4 of 5 met papillen orerdekte stijlen draagt en omgeven wordt door een twe e tal bla a djes. Omtrent de vraag, of men hier met een perigoon, dan wel met steelblaadjes te doen heeft, bestaat nog steeds verschil van meening. Hierop kom ik in de volgende paragraaf terug. De beide genoemde blaadjes zijn aan hun basis met elkander vergroeid, zoodat zij op eene dwarsche doorsnede door de bloem zich als een ring rondom het vruchtbeginsel voordoen.

Het vruchtherinsel is éenhokkig en berat slechts cén basalen campylotropen zadalknop. Deze verandert in een zaad, watrin de kiem om hot roedingsweefsel gokromd ligt. Bij het rijp worden blijft de vrucht omeven door de beide genoemde hladeren, welke hard en krakbeenachtig worden en tot aan hun top vergroeien. Hierbij kummen, nl. bij de variëteit spinosi Iforxch, zijdelings uit dit omhulsel 2 tot 4 doorntjes ontstaan.

Soms treft men in mannelijke bloemen cen rudimentair vruchtbeginsel aan. Komen er tweeslachtige bloemen voor, dan zijn deze steeds gebouwd als de mannelijke. 


\section{$\S 4$. De ontwikkeling der bloem.}

Sprekend over de bloemontwikkeling der Che nopodiaceae, zegt $\mathrm{PAYER}^{1}{ }^{1}$ ): "Les plantes de cet ordre se ressemblent tellement entre elles dans leur structure florale essentielle, qu'en connaître une, c'est les connaître toutes". Daarom behandelt hij slechts, als typisch roor de orde, de bloemontwikkeling van Suaeda fruticosa.

De vijf kelkbladen ontstaan hier successievelijk en blijven aan hun basis vrij. Aan de voorzijde, d.w.z. aan de van de as afgekeerde zijde, van de bloem liggen het $1^{\mathrm{e}}$ en het $3 \mathrm{e}$ kelkblar; achter, in het mediaanvlak staat het $2^{\mathrm{e}}$ en ter weerszijden daarvan de kelkbladen 4 en $\check{5}$. Bij geen der bestudeerde Chenopodiaceae werd eenig spoor van petalen aangetroffen. De meeldraden rerschijnen tegelijkertijd, staan tegenover de kelkblarlen en groeien zeer snel. Kort na het optreden der meeldraden ontstaan om den top van den bloembodem drie papillen voor de carpellen. Bij Su a da rerschijnen deze tegelijk, bij andere geslachten, bijv. Beta, na elkander en wel achtereenvolgens boven de sepalen 1, 2 en 3. Spoedig vergroeien de drie beginsels der carpellen tot een wal, welke zich naar boven tot een korten stijl vernauwt, terwijl de drie lobben van den rand tot drie vertakte stempels uitgroeien. Van deze stempels zijn er dus meestal twee naar voren en één in het mediaanvlak naar achteren gekeerd. De zaadknop ontstaat volgens Payer zoo, dat om den top van den bloembodem twee ringvormige verhevenheden voor de integumenten optreden, waarna deze top zelf uitgroeit en de nucellus

1) Payer, Traité d'organogénie comparée de la fleur. Paris, 1857, p. $308-309$. 
wordt van ren zaadknop, die bij S u a e d a rechtopstaand en anatroop is.

Bij sommige Chenopodiaceae ontstaan slechts twee beginsels voor de carpellen. Deze staan dan beide in het mediane vlak, zoodat er één boven het $2 \mathrm{e}$ kelkblad ligt en er één tusschen het 1e en 3e kelkblad naar voren is gekeerd.

Een onderzoek nar de ontwikkeling der vrouwelijke bloemen van Spinacia kwam mij wenschelijk voor, omdat daaruit misschien cene conchusie zou zijn te trekken omtrent den aard der om het rruchtbeginsel aanwezige blaadjes. Volkens ${ }^{1}$ ) meent, dat bij alle C y clolobea e Atripliceae onder de Chenopodiaceate de mannelijke bloemen wel een perigoon en geen steelblaadjes, de vrouwelijke daarentegen wel steelblaadjes en ineestal geen perigoon hebben. Bij de vrouwelijke bloemen van A triplex bestaat daarover wel geen twijfel. Hier staan de bewuste blardjes transversaal, zooals dat voor steelblarlen algemeen gelitt, en kunnen zij zelfs bloemen in hunne oksels dragen. Bij het nauw verwante geslacht Exomis vindt men er boven nog rudimenten van een perigoon, zoorlat zij ook hier ongetwijfeld als steelblarlen moeten worden beschouwd. Eichler ${ }^{2}$ ) beweert echter, dat bij de geslachten Spinacia en Eurotia de vrouwelijke bloemen evenals de mannelijke een perigoon en geen steelblaadjes hebben. Dit bloemdek zou dan tweetallig zijn.

Bij het bestudeeren van de ontwikkeling der vrouwelijke bloemen bleek het mij, dat de carpellen optreden als twee mediain gelegen verhevenheden. Deze ver-

\footnotetext{
1) $1 . \mathrm{c}$.

2) HichLER, Blütendiagramme. II. p. 77-84.
} 
groeien bij de verdere ontwikkeling zijdelings met elkander en doen zoo het vruchtbeginsel ontstaan. Aan den top vertakken zij zich meestal, zoodat in den regel vier stempels gevormd worden.

In datzelfde mediane vlak verschijnen nu ook de beginsels der beide besproken blaadjes.

Evenals bij de eerste ontwikkeling der carpellen worden deze verhevenheden aan hun voet voortdurend breeder, nemen een halvemaan-vorm aan en vergroeien ten slotte zijdelings met elkander. Daar steelblaadjes, wanneer er ten minste twee aanwezig zijn, transversaal plegen te staan, kunnen wij dus met Eichler ainnemen, dat bij de vrouwelijke bloemen van Spinacia wel perigoonbladen en geen steelbladen optreden.

Een zeer belangrijk argument, dat er toe leidt de blaadjes in kwestie te beschouwen als perigoonbladen en niet als steelbladen, is verder, dat soms een dezer bladen een dubbelgekielden rug heeft, zooals ik dit bij de eerste ontwikkeling eener bloem in enkele gevallen heb waargenomen. Hieruit kan men de gevolgtrekking maken, dat ook bij de vrouwelijke bloemen evenals bij de mannelijke oorspronkelijk vier periguonbladen aanwezig zijn, die echter twee aan twee in het mediane vlak vergroeid zijn. Van belang in verband hiermede is ook de mededeeling van BAILLON ${ }^{1}$ ), dat van de bedoelde blaadjes er soms drie of vier in eene vrouwelijke bloem kunnen voorkomen.

Volkexs meent, dat wanneer bij de variëteit $\mathrm{Sp}$ in os a Moench aan de vrucht meer dan twee, nl. drie of vier, doorntjes voorkomen, dit verklaard moet worden door eene splitsing van de twee oorspronkelijk aan-

1) Baillon, Histoire des Plantes. T. IX, p. 135. 
wezige steelblaadjes. Het komt mij voor, dat het optreden van drie of vier doorntjes aan de vrucht beschouwd kan worden als aroument voor LirnuER's opvatting, dat bij de vrouwelijke bloem van Spinacia perigoonblaten en niet steelblaaljes roorkomen. Wanneer $\mathrm{nl}$. de twee meestal aanwezige perigoonbladen door versroeing twee aan twee uit vier zijn ontstaan, beteekent het optreden van drie of vier doorntjes aan de vruchten eenroudig een weer zichtbaar worden van de dubbele natuur dezer beide perigoonbladen.

De zaadknop is van twee integumenten voorzien en groeit in het mediane vlak campylotroop om en wel van voren naar achteren. De funiculus, die zeer kort is, ligt dus aan de voorzijde van de bloem, de micropyle is naar achteren en naar beneden gekeerd. Zoodoende ligt ook de ringrormig om het voedingsweefsel gekromde kiem later in het mediane vlak, m.a. w. in het vlak der twee doornachtige uitsteeksels van het perigoon, wanneer deze ten minste aanwezig zijn. Daarbij is dan natuurlijk het kicmworteltje ook naar achteren en naar beneden gekeerd, terwijl de cotylen aan de voorzijde liggen.

Yooals boven reers is medegedeeld, stelt PAYER zich voor, dat de zaadknop ontstaat uit den top van den bloembodem. In het algemeen neemt men echter voor het weval, dat slechts fén bodemstandige zaadknop aanwezig is, aan, dat deze bij één der carpellen behoort en zeer laag op den rand datrvan is ingeplant. EICHLER ') neemt dit dan ook voor den zaadknop der Chenopodiaceae aan, en noemt daarvoor als argument, dat bij Orthosporum, een ondergeslacht van Chenopo-

1) 1. c. p. 81. 
dium, de zaadknop duidelijk uit den wand van het ovarium ontstaat. Ook hier meen ik, dat EIchlen's opratting de juiste is en wel op grond van de volgende waarneming. In een schotel met ontkiemde spinaziezaden trof ik namelijk eens eene vrucht aan, waaruit twee gelijke hoofdwortels te voorschijn kwamen. A priori zou dit op verschillende oorzaken kumnen berusten. De mogelijkheid bestond, dat als geval van Polyembryonie twee kiemen in cén zaad aanwezig waren; maar ook kon de vrucht twee zaden bevatten.

Het eerste was weinig waarschijnlijk, daar A. BRAux 1) Spinacia niet noemt in zijne bekende lijst van planten, bij welke Polyembryonie voorkomt en ook omdat later geen mededeelingen daaromtrent zijn versehenen. Bij onderzoek bleek dan ook, dat in deze vrucht twee volkomen gelijke zaden aanwezig waren, elk ongeven door een eigen zaadhuid.

Zoolang in het vruchtbeginsel slechts één zaadknop aanwezig is, zou men kunnen aannemen, dat deze uit den top van den bloembodem werd gevormd. Wanneer er echter twee in voorkomen, meen ik, dat het duidelijk is, dat beide bij de carpellen behooren en uit de randen daarvan zijn ontstaan.

Als resultaat van mijn onderzoek van de ontwikkeling der bloem bij Spinacia, kan ik dus voor de meening van Eichler, dat men in de twee blaadjes, welke in de vrouwelijke bloemen dezer plant het vruchtbeginsel omgeven, perigoonblaadjes heeft te zien, en dat de zaadknop niet op den top van den bloembodem en dus eindstandig, maar op den rand van een

1) A. BRAUn. Ueber Polyembryonie und Keimung von Coelebogyne. Abh. d. K. Ak. d. W. zu Berlin, 1859. 
der carpellen staat, als verdere argumenten aanvoeren: $1^{\mathrm{e}}$. dat de bedoelde blaadjes mediaan staan.

$2^{\text {e }}$. dat zij somtijds een dubbel gekielden rug vertoonen.

$3^{e}$. dat in het vruchtbeginsel twee zaadknoppen kunnen voorkomen, waardoor eene inplanting op den top van den bloembodem is buitengesloten of tenminste zeer onwaarschijnlijk wordt. 


\section{HOOFDSTUK II.}

\section{METHODEN VAN ONDERZOEK.}

\section{$\S 1$. Het vervaardigen der praeparaten.}

Bij het vervaardigen mijner praeparaten volgde ik de methoden, zooals die in het laboratorium van Professor Strasburger te Bonn worden toegepast. Eene beschrijving dier methoden is misschien aan velen niet onwelkom en moge daarom hier volgen.

Fixeering. Om praetische redenen verdient het aanbeveling in den regel het materiaal 's morgens te fixeeren. Daarbij worden hoofdzakelijk de volgende fixatie-vloeistoffen gebruikt.

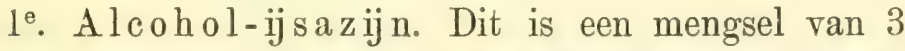
deelen absoluten alcohol en 1 deel ijsazijn, dat steeds onmiddellijk vóór het gebruik moet bereid worden, daar door een langdurig staan der vloeistof de aethyl-azijnesther ontstaat, die voor de fixatie waardeloos is en dus het werkzame bestanddeel te zeer vermindert. De vloeistoffen worden daarbij op het oog bij elkander gevoegd in het buisje, waarin men het te fixeeren materiaal wil brengen. Het gebruik van dit fixeermiddel is boven dat van het hieronder te bespreken Flemming's mengsel in die gevallen te verkiezen, waarin de objecten in het laatste niet onderzinken, 
zooals dat bijp. het geval is met bloemen van Alchemilla. In alcohol-ijsazijn blijven de gefixeerde voorwerpen 1 dag staan. Den volgenden morgen wordt de vloeistof uitgegoten en wordt er absolute alcohol voor in de plaats gebracht. Hierin laat men de objecten een nur staan, gict weer af en voegt nieuwen absoluten alcohol toe. Dit herhaalt men drie of vier maal, tot de reuk van den ijsazijn niet meer bemerkbaar is.

2. Een mengel volgens Fumming, bestaande uit $180 \mathrm{cM}^{3}$. van eene $1 \%$ chroomzuur-oplossing, waarbij $25 \mathrm{cNI}^{3}$. $2 \%$ osmiumzuur, $12 \mathrm{cM}^{3}$. ijsazijn en $210 \mathrm{cM}^{3}$. gedistilleerd water revoegd zijn. Deze rloeistof behoort in het donker in eene gele flesch bewaard te worden, daar in water opgelost osmiumzuur aan het licht niet houdbaar is. De $25 \mathrm{cM}^{3}$. van eene $2 \%$ osmiumzuuroplossing, noodig bij het bereiden van dit mengsel, verkrijgt men op zeer eenvoudige wijze door een buisje met 0,5 gram osmiumzuur, zooals dat in den handel voorkomt, met $25 \mathrm{cM}^{3}$. water te schudden tot het breekt, en dan den inhoud op te laten lossen. Dit fixeermiddel verdient vooral ambeveling met het oog op kleuring mer safranine-gentianaviolet-orange G. Datr het ehroomzuur slichts zeer meeilijk in de objecten binnen dringen kan, zorge men er voor, deze zoo klein, als mogelijk is, te nemen. Dit geldt trouwens als algemeene regel voor alle fixatie-vloeistoffen. Ook moet men er steeds voor zorgen, dat het volumen van de vloeistof het veelvoudige is van dat der objecten. Evenals in het mengsel van alcohol en ijsazijn het laatste dient om de contra-

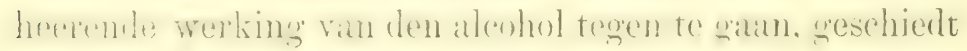
hier het toevoegen van azijnzuur, om eene plasmolyseerende werking van het chroomzuur te verhinderen. Dit laatste werkt ook daardoor nog nadeelig; dat het 
tengevolge kan hebben, dat bepaalde albuminoiden neerslaan, en wel in den vorm van draden, die vaak zoo tot een netwerk vereenigd zijn, dat men ze voor structuren van het protoplasma zou kunnen aanzien. Het osmiumzuur dringt bijzonder snel door, veroorzaakt echter een zwart worden der objecten.

In „Flemming” blijven de objecten 2 dagen. Dan bedekt men het fixatic-buisje met een dubbel gevouwen lapje neteldoek en plaatst het voor den tijd van 2 uur onder de waterleiding. Daarna moeten de voorwerpen overgebracht worden in absoluten alcohol, hetgeen geleidelijk moet geschieden. Het beste is, wanneer men het zóó kan inrichten, dat alcohol van 30\%, $50 \%, 70 \%$ en $85 \%$ op 1 dag ieder 2 uur kunnen inwerken en de objecten dan een nacht in alcohol van $96 \%$ kunnen doorbrenges. Een langer opmenthour dan 2 uur in alcohol van $70 \%$ schaadt niet, echter wel in alcoholen van lager $\%$ of in water; ik heb mij daarvan persoonlijk overtuigd en vond dat de kleuring dan veel minder goed slaast. In aloohol ran $96 \%$ moeten de voorwerpen echter 6 à 12 uur doorbrengen. Daarna late men ze nog 2 maal 2 uren in absoluten alcohol vertoeven.

$3^{\text {. }}$ JUEL's o p los sing, bestaande uit 2 gram zinkchloride en $2 \mathrm{cM}^{3}$. ijsazijn op $100 \mathrm{cM}^{3}$. $50 \%$ alcohol. Men behoeft hier niet met water uit te spoelen, maar begiet de objecten met alcohol van $70 \%$, dien men terstond door nieuwen vervangt, waarin nu de objecten kunnen blijven staan. Zoowel voor kleuring met safranine-rentianaviolet-orange $\left(\frac{1}{x}\right.$, als met ijzer-haematoxyline, is dit fixatiemiddel geschikt.

4. Guignard's oplossing, bestaande uit 0,5 gram chrormzuur, 0,5 gram officined ijzerehloride en $2 \mathrm{cll}$. ijsazijn op 100 gram water. 
Voor de fixatie van bloemenmaterial van Spinacia heb ik rooral alcohol-ijoazijn grebruikt, warbij zoowel de mammelijke als de vrouwelijke inflorescenties in hun geheel werden afgeplukt en in de vloeistof gebracht. Voor wortels heb its alle grenoemde fixatie-rloeistoffen toegepast.

Het overbrengen in paraffine. Bij alle fixatiemethoden komen de objecten ten slotte in absoluten alcohol. Deze wordt vervangen door een mengsel van gelijke deelen alcohol en chloroform, waarin de voorwerpen aanvankelijk drijven. Nen wacht nu tot alles ondergezonken is, hetgeen bij kleine objecten 1 dag, bij grootere 2 à 3 dagen kan duren. Daarna vervangt men het mengwel dom zuivere chloroform, warin eveneens de objecten eerst drijven, ten slotte echter moeten zinken. Dit neemt ook 1 à 2 dagen in beslag. Zijn zij dan nog nict gezonken, dan plaatst men het buisje, na de kurk losgemakt te hebben, boven op den thermostaat. Door de verwarming wordt dan het zinken bespoedigd.

$\mathrm{Nu}$ brengt men de voorwerpen, met zooveel chloroform, dat zij even er door bedekt worden, in een porceleinen kroes met vlakken bodem en vertikalen wand en vult dezen verder aan met schilfers van paraffine van $52^{\circ} \mathrm{C}$. smeltpunt. Het verdient aanbeveling in den kroes een etiquetje met de noodige aanwijzingen te leggen, dat tevens, wanneer de paraffine in den thermostaat, die op $55^{\circ} \mathrm{C}$. wordt gehouden, gesmolten is, kan dienen om elken dag de paraffine om te roeren. Hierdoor wordt het verdampen van de chloroform hevorderd, en is deze in $2-3$ dagen, soms echter eerst na eene week verdreven.

Het snijden. Om de objecten in blokjes paraffine te brengen, die geschikt zijn, om met den microtoom 
gesneden te worden, gaat men als volgt te werk. Een rechthoekig porceleinen schaaltje, 5 c.M. lang, 4 c.M. breed en 1 c.M. diep, wordt goed ingewreven met glycerine en een weinig verwarmd. Dan kan men òf den kroes met de roorwerpen er in leeggieten en de laatsten naar verkiezing rangschikken ò wel men kan afzonderlijk gesmolten paraffine er in gieten en de objecten uit den kroes er met een warm pincet één voor één in overbrengen. Het heeft niet het minste bezwaar, dezelfde paraffine te gebruiken, mits de chloroform er uit verdampt is. Wanneer dit laatste niet het geval is, kan het tot moeilijkheden bij het snijden aanleiding geven. Zoo wordt bijv. het afbrokkelen van den rand van een blokje bij het snijden aan het nog aanwezig zijn van chloroform toegeschreven. Men gaat verder op de volgende wijze te werk. Het etiquetje wordt bij een der hoeken van het porceleinen schaaltje op de paraffine gelegd en het schaaltje wordt naar een koeler plek van de tafel geschoven; dan laat men het op koud water drijven en als er een vlies over de paraffine is grekomen, laat men het zinken. Na eenigen tijd komen de gregoten blokken van zelf boven drijven. Dan worden zij in stukken verdeeld, die ieder één object bevatten en op den daarvoor bij den microtoom behoorenden objecthouder bevestigd kunnen worden. Gewoonlijk wordt te Bonn met een "Schlittenmikrotom" naar Thoma-Yung gesneden. Daarbij worden als objecthouders rechthoekige houten blokjes gebruikt in welker bovenste helft een weinig lood is aangebracht. Wanneer men nu de paraffineblokjes op deze veel grootere houten blokjes bevestigd heeft, maakt men de kanten met behulp ran een warm scalpel zuiver rechthoekig en dompelt ze in een glas water ter afkoeling onder. De aanwezigheid van het lood bewerkt 
dan, dat de kant met het object onder water blijft. Thans kunnen de doorsneden worden vervaardigd. Meestal wordt ter dikte van $10 \mu$ gesmeden. Zulks deed ik gewoonlijk ook bij Spinacia, hoewel ik soms ook coupes van $5 \mu$ dikte bestudeerd heb.

Het opplakken der doorsneden. Men gebruikt steeds voorwerpglazen van 26 bij 76 m.M. grootte. Zij worden goed ingewreven met een weinig eiwit-glycerine

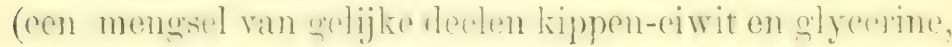
watrbij ren weinie kamfer gevoegd wordt, om let horlert tegern te gatan). Datarna worden er met een druppelbuisje eenige druppels water opgebracht, waarop men nu de gemaakte coupes laat drijven. Het valt dan zeer gemakkelijk de doorsmeden te rangschikken, waarbij met hot format rim het dekelas (gebruikelijk rijn die van 25 bij 45 m.M.) rekening gehouden moet worden. Dan zet men het objectglas een oogenblik rechtop en laat zoodoende het overtollige water weer afloopen. Daarna komen de praeparaten rool minstens een paar uur (overnacht bijv. is volstrekt niet te lang) in den themostatat (hij $55^{0} \mathrm{C}$.) te liggen, bij voorkeur boven op de porceleinen kroezen, die er in staan. Hierdoor bewerkt men, dat de doorsneden stevig en zonder rimpels op de glazen geplakt worden. Uit den oven genomen en af-

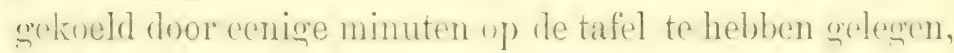
komen de praeparaten vervolgens in xylol, waardoor in 5 à 10 minuten de paraffine wordt opgelost. Een verblijf van meerdere dagen in xylol is volstrekt niet schadelijk. Na uit deze vloeistof genomen te zijn, wordt het praeparaat met alcohol van $96 \%$ of met gebruikten absoluten alcohol begroten om van de rettige xylol bevrija te worden, en daarna in een glas water af'gespoeld.

Kleuring. In alle gevallen warin met "Flemming" 
was gefixeerd, moet men nu het praeparaat in eene $3 \%$ waterstofsuperoxyde-oplossing brengen, om de zwarte kleur van de doorsneden door oxydatie te doen verdwijnen. Hiervoor zijn 2 à 3 uur noodig en voldoende. Wil men later met safranine-gentianaviolet-orange $G$ kleuren, dan zorge men er voor, dezen tijd niet te lang te nemen, daar in dat geval de kleuring wel eens niet goed gelukt. Bij kleuring met haematoxyline schaadt echter een langer verblijf in waterstofsuperoxyde niet. In plaats van waterstofsuperoxyde is ook te gebruiken eene oplossing van 2 gram kaliumchloraat in 100 c.M. $\mathrm{M}^{3} .70 \%$ alcohol, waarbij 2 druppels geconcentreerd zoutzuur gevoegd zijn.

In die gevallen, warin gefixeerd was met eene vloeistof, welke alcohol maar geen chroomzuur bevatte, dus bijv. met alcohol-ijsazijn of met JUEL's fixecrvloeistof, moet het praeparaat, wanneer met safranine-gentianavioletorange G gekleurd zal worden, nadat het uit de xylol gekomen en met alcohol en water afgespoeld is, in eene $1 \%$ chroomzuuroplossing gebracht worlen. Het chroomzuur maakt de weefsels meer geschikt, om die kleuren vast te hourlen, en moet 2 à 3 uur of langer inwerken, waarna men een kwartier tot een half uur goed onder de waterleiding spoelt. Deze inwerking van chroomzuur is overbodig, wanneer inen met haematoxyline wil kleuren.

De beide te Bonn hoofdzakelijk gebruikte kleurmethoden zijn die met ijzer-haematoxyline naar Heidenhain en die met safranine-gentianaviolet-orange G, bekend als Flemming's driekleuren methode.

Voor de kleuring met $\mathrm{h}$ a e matoxylin e volgens Heidenhain heeft men twee vloeistoffen noodig.

$1^{\mathrm{e}}$. Eene oplossing van hae matox y line, welke men 
bereidt door 2 gram dezer stof op te lossen in een weinig absoluten alcohol en dan water toe te roegen tot 100 c.MI". Door toevoeging van enkele druppels waterstofsuperoxyde bewerkt men, dat de vloeistof langer goed blijft.

2 e. Eene $3 \%$ oplossing van ijzeraluin (Schwefelsaures Eisenoxydammon van (xrübler). Na uit de xylol genomen, met alcohol en water afgespoeld en zoo noodig (wanneer n.l. met „Flemming”" gefixeerd was) door waterstofsuperoxyde gebleekt en daarna nog even in water gespoeld te zijn, komt het praeparaat in een cylinderglas met ijzeraluin, welke zeer rein gehouden moet worden en alleen voor dit doel mag worden gebruikt.

De weefsels worden hierdoor geschikt gemaakt om de kleurstof op te nemen. Het praeparaat blijft er minstens eenige uren in, maar eene langere inwerking is niet nadeelig. Dan wordt het 5 minuten lang onder de waterleiding gespoeld en komt het in de $2 \%$ haematoxyline-oplossing. Verschillende objecten gedragen zich hier op zeer verschillende wijzen. Sommige kunnen reeds na een half uur, andere eerst nat reel langeren tijd verder hehandeld worden. Daarbij moet opgemerkt worlen, dat de kleuring des te beter slaagt, hoe ouder de oplossing is. Steeds moet ook de oplossing tegen den invloed ram het licht beschermd worden. Mijne praeparaten van wortels en bloemen van Spinacia vertoefden dikwijls slechts een half uur in de haematoxyline-oplossing en werden dan terstond verder behandeld. D. w. z. zij werden even in een glas met water afgespoeld en dan in een nieuw cylinderglas met ijzeraluin gedifferentieerd. De kleur trekt hier snel uit, hetgeen men onder het microscoop moet controleeren. Zoodra de gewenschte détails scherp uitkomen, brengt men het praeparaat snel in water, waarin het 10 minuten 
krachtig gespoeld moet worden. Blijft er nl. eenig ijzeraluin achter, dan kan dat later tot ontkleuring van het praeparaat aanleiding geven. Is misschien bij het differentieeren de kleur te reel uitgetrokken, dan kan men na j minuten spoelen het praeparaat weer eenigen tijd in de haematoxyline zetten.

Nadat de praeparaten zich gedurende 10 minuten in stroomend water hebben bevonden, ontwatert men ze met alcohol van $96 \%$ en komen zij in kruidnagelolie, waardonr zij opgehelderd worden. De kruidnagelolie trekt de kleur niet uit, zoodat de praeparaten er zoo lang in vertoeven kunnen, als men wil.

Voor de kleuring mets afranine-gentianavioletorange $\mathrm{G}$ heeft men noodig:

$1^{\text {e }}$. eene $2 \%$ oplossing van safranine in alcohol van b) "\%, waarbij eenige druppels anilinewater gevoegd worden, om het bederf tegen te gaan;

2 e ene $2 \%$ oplossing van gentianaviolet in water;

$3^{\text {e }}$. eene oplossing van Orange $G$ van GrüBLER, die ongeveer een half $\%$ sterk is.

Het praeparaat komt het eerst in de safranine-oplosing, voor den tijd van 6-24 uur. Al naar het fixatie-middel gebeurt dit dus terstonu, nadat het uit de xylol genomen en met alcohol en water afgespoeld is (Guignard), of nadat het eerst in waterstofsuperoxyde geweest en met water even afgespoeld is (Flemming), of nadat het eenige uren in chroomzuur van $1 \%$ heeft gestaan en $1 / 4$ uur goed onder de waterleiding afgespoeld is (alcoholijsazijn, Juel). De safranine kleurt de praeparaten te sterk en moet dus worden uitgetrokken. Daarvoor worden de praeparaten eerst in een glas met water gereinigd en rlan begoten met alcohol ran $96 \%$ en zoo noodig met zuren alcohol (eenige druppels zontzuur op 
200 c. $\mathbf{M}^{3}$. alcohol van $96 \%$. Met het nog op de verdere bewerking is het wenschelijk een praeparaat met den laatsten te behandelen. Men controleert telkens onder het microscoop of de roode kleurstof voldoende is uitgetrokken, terwijl tevens nucleolen en chromosomen fraai rood moeten blijven. Is dit het geval, dan spoelt men weer in water af en plaatst het praeparaat in een cylinderertas met gentianaviolet. De duur van inwerking hiervan moet men voor ieder object door probeeren vinden. De bedoeling is, dat de spoelen violet gekleurd worden en de weefsels een blauwachtig roode tint aannemen, terwijl de chromosomen en nueleolen fraai rood blijven uitkomen. Meestal duurt dit 1 minuut of iets langer. Dan wordt het praeparaat weer in water afgespoeld en giet men er met een druppelbuisje eenige druppels van de orange G-oplossing op. Orange G heeft de eigenschap het gentimaviolet te differentieeren en het cytoplasma te kleuren. Gedurende $1 / \mathrm{s}$ minuut, of zooveel langer als noodig blijkt, schudt men het praeparaat nu heen en weer, giet dan het orange $f$ af, en spoelt de rest er van met alcohol van $96 \%$ weg: Hiermede schuit men het roorwerpelas eveneens hern en weer tot de afloopende alcohol niet meer de kleur van het gentianaviolet vertoont. $\mathrm{Nu}$ komt het praeparaat in kruidnagelolie. Hierin bewerat men het met behulp van een pincet eenige malen heen en weer tot de kruidnargelolie gelijkmatig aftoopt, wannere men het praeparaat er uit neemt. Dan laat men het er weer rustig in staan. In dit geval trekt de kruidnagelolie de kleurstof wel uit; men controleert dus dit uittrekken onder het microscoop en zoodra het praeparaat roldoende is opgehelderd, neemt men het er uit en brengt er canada-balsem en ecn dekglas op. 
Zoowel bij materiaal van bloemen als bij dat van wortels van Spinacia voldeed deze kleuring mij minder goed, dan die met haematoxyline. Daarom heb ik vooral de laatste aangewend. De oorzaak daarvan lag in het onscherp kleuren door de safranine. Nog eenige andere klemingen heb ik geprobeerd, zooals bijv. haematoxyline met Orange $G$, haematoxyline met gentianaviolet, gevolgd door inwerking van kruidnagelolie, waarin $1 \%$ eosine was opyelost, enz. Mijne teekeningen zijn echter alle vervaardigd naar praeparaten, die eenvoudig met haematoxyline waren gekleurd.

Hier wil ik nog wijzen op eene methode, om in gevallen, waar de bloemen in dichte kluwens staan en waar slechts één enkele zaadknop in het rruchtbeginsel voorkomt, zooals bij Spinacia, mediane lengte-doorsneden te verkrijgen. Nadat het materiaal overgeroerd is tot in absoluten alcohol, vervangt men dezen door alcohol, waarin 1 à $2 \%$ eosine is opgelost, zoodat alle bloemen hierdoor in hun geheel worden gekleurd. Dan trekt men met absoluten alcohol de kleurstof weer zooveel mogelijk uit, voert over in chloroform en paraffine en bij het gicten der paraffine-blokken praepareert men de jongste bloemstadien, die nu, dank zij de roode kleur, zeer goed zichtbaar zijn, van elkander los. Zij plaatsen zich hierbij dikwerf zoo, dat men door parallel met den bodem van het porceleinen schaaltje te snijden, mediane doorsneden verkrijgt.

\section{§2. Technische bijzonderheden.}

Bij het onderzoek der praeparaten gebruikte ik steeds de apochromatische homogene immersie 2 m.M., num. 
apertuur 1.30 m.M. van CarL Zeiss met de verschillende compensatie-oculairen. Daar in den regel het daglicht te zwak is bij het gebruik der sterkere oculairen, heb ik gewoonlijk met gasoloeilicht grewerkt, waarbij een glazen, met cene ammoniakale kopersulfaat-oplossing gevulde, bol als lichtfilter dienst deed.

Zooals ik reeds opgemerkt heb, levert Spinacia, vooral in de ontwikkeling van het stuifmeel, cen bijzonder gunstig materiaal op voor het onderzoek der reductiedecling. Daar de mannelijke bloeiwijzen in hun geheel gefixecrd en met den microtoom gesneden werden en dus jongere zoowel als oudere blocmen tegelijk getroffen werden, kwamen in één enkel praeparaat allerlei verschillende ontwikkelingstoestanden der stuifmeel-moedercollen voor. Ook bevinden zich de verschillende antheren cener zelfde bloem in verschillende stadiën van ontwikkeling en kunnen in één zelfde anthere boven en beneden andere toestanden voorkomen, die dan door alle overgangen met elkander verbonden zijn. In één praeparaat komen verder gewoonlijk, tengevolge van den grooten rijkdom der antheren aan pollen in elk dezer toestanden een zeer groot aantal moedercellen voor. Dit levert een duidelijk in het oog vallend voordeel op. Wanneer men éénzelfde stadium tegelijkertijd in een groot aantal moedercellen kan bestudeeren, zal men beter kumnen beoordeelen, wat tot het karakter van dat stadium behoort en zal men dus ook met grooter zekerheid die moedercellen voor zijue teekeningen kunnen uitkiezen, die dat bepaalde stadium het beste vertegenwoordigen.

Met het oog op het vergelijken der figuren ten opzichte van de grootte, was het van belang bij het ontwerpen van alle teekeningen dezelfde voorschriften in acht te nemen. Hier moge dus nog de 
wijze van teekenen in bijzonderheden worden opgegeven. Ik gebruikte een teekenapparaat volgens ABBE van ZEIss. Het teekenpapier lag op een hellend vlak, iets beneden de tafel van het microscoop, die er evenwijdig mede werd gesteld. Wanneer ik het compensatie-oculair 18 gebruikte, werd bij het teekenen de tubus tot 145 mM. uitgetrokken, daar aan het microscoop een revolver voorkwam en in dit geval de gebruikelijke tubus-lengte van $160 \mathrm{mM}$. verminderd moet worden met de 15 m.I., die de revolver hoog is. Werd met de compensatie-oculairen 8 of 12 geteekend, dan moest daarvan het ringstuk worden weggenomen, ten gevolge waarvan de oculairen dieper in den tubus zakten. Deze werd daarom weer zooveel verder uitgetrokken, als de ringstukken breed waren. Daar ik verder opgemerkt heb, dat het een groot verschil maakt in de afmeting der teekeningen of de spiegel van het teekenapparaat iets meer of minder helt ten opzichte van het teekenpapier, heb ik er steeds voor gezorgd, dat de spiegel den grootst mogelijken hoek met het vlak van teekening maakte. 


\section{HOOFDSTUK III.}

\section{DE VERMEENDE APOGAMIE VAN SPINACIA.}

$\S 1$. Over het verband tusschen Apogamie en het aantal der Chromosomen.

In den laatsten tijd heeft het zeer de aandacht getrokken, dat er tusschen apogamie en het antal der chromosomen een verband schijnt te bestaan. $\mathrm{Nu}$ en dan komt bij verschillende soorten van eenzelfde geslacht of zelfs bij elementaire soorten van eenzelfde systematische soort een verschillend aantal chromosomen voor. Daarbij kan het zijn, dat één of meer vormen eener groep een dubbel zoo groot aantal chromosomen hebben, als de overige vertegenwoordigers dezer groep, maar ook kunnen bij de verschillende soorten andere getalsverhoudingen optreden. In het eerste geval pleegt men thans wel aan te nemen, dat eene lenotesplitsing der chromosomen de oorzaak was van de verdubbeling; in het laatste geval is het niet onwarrschijnlijk, dat dwarsche doorsnoeringen bij de verandering van het aantal eene rol speelden.

Door verschillende schrijvers is er op gewezen, dat apogame planten zoo dikwijls door hooge aantallen van chromosomen uitmunten. In vele gevallen hebben de apogame soorten daarbij juist het dubbele aantal van dat der normaal-geslachtelijke verwanten. IIet komt mij 
nu voor, dat hier meer de nadruk op verdubbeling, dan wel op de absolute grootte van het aantil gelegd moet worden. Ik wil trachten, dit aan de hand der bekende voorbeelden aan te toonen. De gevallen, die in aanmerking komen, om hier te worden genoemd, zijn in de eerste plaats Antennaria, Alchemilla, Thalictrum, Taraxacum, Rosa en Hieracium en in de tweede plaats Wikstroemia en verschillende varens. Het is wenschelijk, elk dezer voorbeelden met de noodige bijzonderheden te schetsen.

A ntennaria dio ica is normaal geslachtelijk. $\mathrm{Bij}$ de vegetatieve deelingen treden 24 chromosomen op. De reductie-flecling is normaal. De embryozak-moedercel vormt eene normale tetrade en uit de meest basale van de vier cellen ontstaat de embryozak. Daarentegen vindt JUEL ${ }^{1}$ ) bij de eveneens dioecische A. alpina ongeveer 50 chromosomen en eene apogameontwikkeling van het embryo. De mannelijke planten zijn zeer zeldzaam en vertoonen eene degeneratie van het pollen. Bij de vrouwelijke planten ontwikkelt zich de embryozakmoedercel rechtstreeks tot den embryozak. Hierin hebben echter alle kernen hetzelfde aantal chromosomen als de vegetatieve kernen ran de moederplant, omdat de kern van de embryozak-moedereel zich, hoewel zij het synapsis-stadium doorloopt, toch zonder reductie deelt. Hetzelfde zien wij bij het geslacht Alchemillaz).

1) O. JUEL. Vergleichende Untersuchungen ïber typische und parthenogenetische Fortpflanzung bei der Gattung Antennaria. Kgl. Srenska Vet.-Akad. Handl., Bd. 33, No. 5, 1900, p. 22 en 36.

2) Sv. Murbeck. Parthenogenetische Embryobildung in der Gattung Alchemilla. Lunds Univ. Arsskrift, Bd. 36, Afd. 2, No. 7, 1901.

E. Strasburger. Die Apogamie der Eualchimillen und allgemeine Gesichtspunkte, die sich aus ihr ergeben. Jahrb. f. wiss. Bot., Bd. XLI, 1905, Heft 1, p. 88-164. 
Alchemilla arvensis heeft normaal stuifmeel en kan slechts na bevruchting zaden ontwikkelen. Bij de vegetatieve deelingen komen 32 chromosomen voor en in de kernen der pollen-moedercellen zijn duidelijk 16 paren te tellen. Daartegenover staat, dat alle zoogenamde $\mathrm{Eualchemillen}$ in hunne vegetatieve deelingen 64 chromosomen vertoonen en in verband daarmede 32 paren in de pollen-moedercellen. Voor het grootste gedeelte nu zijn de Eualch emillen apogaam: op de synapsis volgt hier niet het stadium der diakinese, maar de deeling wordt eene vegetatieve, zoodat ook de kernen van den embryozak 64 chromosomen bevatten. Slechts enkele subnivale Eualchemillen vormen eene uitzondering en hebben de reductie-deeling in de pollen- en embryozak-moedereellen behouren. Ifet stuifmeel is hier normaal, bevruchting is noodzakelijk en het ontstaan van bastaarden mogelijk.

Een belangrijk geval vindt men bij het geslacht Thalictrum. Overtor ${ }^{1}$ ) deelt mede, dat bij beparalie soorten, zooals bijv. Thalictr u m m in us, die niet apogaam is, het gereduceerle amtal chromosomen 12 en het vegretatieve aantal dus 24 is. Deze getallen zijn dubbel zoo groot bij 'Th. purpurascens, voor welke door Overton 2 ) apogamie beschreven is. 'Thalictrum purpurascens is evenals 'Thalictrum dioicum dioecisch en brengt goed kiembaar stuifmeel voort. Maar terwijl nu Thalictrum dioicum ook in andere opzichten normaal is, vertoonen de vrouwelijke planten van Th. purpurascens eene afwijking. Slechts een deel

\footnotetext{
1) J. B. Overton. Organization of nuclei in pollenmothen'cells. Annals of Bot., XXIII, Na. LXXXIX, Jan. 1909.

$\left.{ }^{2}\right)$ J. B. Oventon. Ueber Parthenogenesis bei Thalictrum purpurascens. Ber. d. D. Bot. Ges., Bd. 22, 1904, p. 274-283.
} 
der bloemen heeft hier de gewone reductie-deeling; maar in de overige doorloopen de embryozak-moedercellen slechts de prophase dezer deeling. Dan verandert de deeling weer in eene vegetatieve. De vorming van den embryozak geschiedt verder geheel op de gewone wijze; slechts vertoonen de kernen dubbel zooveel chromosomen, als er in zouden voorkomen, wanneer de reductie-deeling een normaal verloop had gehad.

Voor Taraxacum werd de apogamie ontdekt door RAUNKIAER ${ }^{1}$ ). Door castratie-proeven met 12 verschillende vormen kwam deze onderzoeker tot de conclusie, dat wel alle soorten van Taraxacum apogaam zouden zijn. Daarop toonden MurbecK ${ }^{2}$ ) en Kirchner ${ }^{3}$ ) voor eenige soorten van Taraxacum aan, dat werkelijk de eicel zonder bevruchting tot embryo wordt en vond J $\left.{ }{ }^{4}{ }^{4}\right)$, dat haar kern het regetatieve aantal chromosomen bevat. JUEL beschrijft, dat de kern in de embryozakmoedercel de prophase der reductie-deeling doorloopt tot na het synapsis-stadium, zelfs tot aan de diakinese. Dan rerandert de deeling weer ran aard en krijger. de beide dochterkernen toch ieder het vegetatieve aantal chromosomen. Deeling in twee dochtercellen heeft plaats, waarvan dan de onderste tot embryozak wordt. Het stuifmeel is bij de meeste soorten steriel; bij een enkelen vorm bestaat echter reductie-deeling en treedt het

1) C. Radnkmer. Kimdannelse uden Befrugtning hos Maelkebotte Botan. Tidsskr., Bd. 25, 1903, p. 109-140.

$\left.{ }^{2}\right)$ Sv. Morbeck. Parthenogenese bei den Gattungen Taraxacum und Hieracium. Botan. Notiser, 1904.

${ }^{3}$ ) O. Kirchner. Parthenogenesis bei Bliitenpflanzen. Ber, d. D. Bot. Ges., Bd. 22, 1904, p. (83)-(97).

$\left.{ }^{4}\right)$ O. JuEL. Dic Tetradenteilung in der Samenanlage van Taraxacum. Arkir f. Bot., Bd. 2. No. 4, 1904.

O. Juel. Die Tetradenteilungen bei Taraxacum und anderen Cichoriaceen. Kgl. Srenska Vet.-Akad. Handlingar, Bd. 39, No. $4,1905$. 
generatieve aantal der chromosomen 12-13 op; het vegetatieve is 26 . Voor kinten tijed is nu cene mederleeling van Rosexberg ${ }^{1}$ ) verschenen, wail'in hij almgeeft, dat bij Tar. confertum eene typische tetraden-deeling van de embryozak-moedercel plaats heeft. Baarbij wordt de onderste cel der tetrade tot embryozak. Ook bij het ontstaan van het pollen treedt reductic op. Bij deze soort zijn nu in de diakinere 8 paren van chromosomen te zien. Het vegetatieve aantal is dus 16 , het generatieve 8 .

Berruchting is nog nict aungetoond, matar watrehijnlijk. Volgens voN HANDEL-MAZETTI ${ }^{2}$ ) toch komen bij het geslacht 'Litraxacum bastatarlen voor. Ook hier zouden dus de apogame, soorten zich door ecn ongeveer dubbel zoo groot aantal chromosomen van de geslachtelijke onderscheiden.

Hetzelfde schijnt bij het geslacht R o s a het geval te zijn. STRAsburger:) onderzocht rerschillende soorten, zooals Rosa livida, R. c in $n$ a m o mea, R. can ina en vond voor het haploide aantal der chromosomen het getal 8, voor het diploide 16. In den laatsten tijd is nu echter ook bij dit geslacht apogamie bekend geworden. LundströM ${ }^{4}$ ) verkreeg, bijv., bij Rosa glauca Afzeliana Fr. var. dilatans At. na

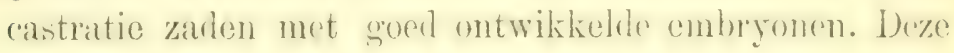
vorm en eene eveneens vermoedelijk apogame variëteit van $R$ os a canina werden nu door Rosenberg ${ }^{5}$ )

3) O. Rosenderg. Ueber die Chromosomenzahlen bei Taraxacum und Rosa. Svensk bot. Tidskr., III, 1909, Heft 2, 150-162, 7 Fig. im 'T'ext.

2) H. von Handel-Mazettr. Monographie der Gattung 'Taraxacum. Leipzig u. Wien, 1907.

3) 1. c.

4) E. LundströM. Kastveringsfürsük med Rosa-former. Svensk bot. Tidskr., III, 1909, Heft 1, (15).

5) 1. c. 
cytologisch bestudeerd. Voor het diploide antal vindt deze onderzoeker hier 33 of 34 , dus het dubbele van het aantal, dat door Strasburger bij normale soorten werd aangetroffen. Bij de reductie-deeling van het stuifmeel nam Rosexbera eigenaardige verschijnselen waar. Nen zou verwachten 16 of 17 paren van chromosomen te zien. Dit is echter niet het geval. In den aequator van de eerste deeling vindt men meestal 7 bivalente chromosomen, terwijl er 20 univalente meer verspreid liggen. Erenals bij den bastaard ran Drosera longifolia met D. rotundifolia blijft een deel dezer laatsten bij het vormen der dochterkernen in de nabijheid ran het aequatorvlakachter en doet daar zoogenoemde d wergkernen ontstaan. Bij de tweede deeling ontstaan dan weer zullie dwergkernen. T'engevolge daarvan worden uit één moedercel vele stuifmeelkorrels gevormd, die echter volkomen steriel zijn. Het komt mij niet on waarschijnlijk vorr, dat dit eigenaardige geedrag der chromosomen met eene bastaardnatuur der genvemde variëteiten van rozen in verband staat.

Als laatste voorbeeld van geslachten van Angiospermen, waarin één of meer apogame vormen voorkomen, die zich door een dubbel aantal chromosomen van de geslachtelijke soorten onderscheiden, kan H i eraci um genoemd worden. Ifierover bestaan talrijke mededeelingen van Raunkiaer, Ostexfeld, Murbeck e. a.. Cytologisch belangrijk zijn rooral die ran Juel en Rosenberg ${ }^{1}$ ).

1) O. JoEL. Die Tetradenteilungen bei Taraxacum und anderen Cichoriaceen. Kgl. Sv. Vet.-Akad. Handl., Bd. 39, No. 4, 1905.

O. Rosenberg. Ueber die Embryobildung in der Gattung Hieracium. Ber. d. D. Bot. Ges., Bd. 24, 1906, p. 157-161.

O. Rosenberg. Cytological Studies on the Apogamy in Hieracium. Bot. Tidsskr., Bd. 28, 1907, p. 143-170. 
Bij Hieracium umbellatum en H. Auricula, die cene normale berruchting hebben, is het generatieve aantal der chromosomen 9, het vegetatieve 18. Bij de eveneens sexueele H. venosum zijn die getallen 7 en 14. Bij H. ex cellens zijn zij echter 17 en 34. Deze soort is nu wel is waar in staat normale embryozakken voort te brengen, maar meestal ontistan deze apospoor of ook op zoorlanige wijze, dat de 'mulnyozak-moerlereel zich zonder reductie in twee cellen deelt, van welke dan de onderste tot embryozak wordt. Nog grooter aantallen, nl. 21 en 42, werden bij H. fla g e 11 are aangetroffen. Ook deze suort brengt in zelizame gevallen met reductie normale embryozakken ruort, maar meestal ontstaan deze apospoor en zonder reductie.

Bịj verschillende geslachten van Angiospermen gaat dus de mogelijkheid langs apogamen weg zaden tot ontwikkeling te brengen gepaard met een dubbel zoo groot aantal chromosomen, als bij zeer nauw verwante geslachtelijke soorten roorliomt. Niet onwaarschijnlijk is het, dat hetzelfde bij verschillende apogame varens het geval is. Bij Polypodiaceae wordt dikwerf waargenomen, dat langs aposjoren wer prothalliön kunnen ontstaan, die dan hetzelfde aantal chromosomen hebben als de sporophyt. Die prothalliën kumnen dan weer een sporophyt met hetzolfirs a antal chromosomen vourthrengen, hetzij uit de eicel van een onbevrucht archegonium, hetzij uit andere cellen. Terwijl nu bij de P'nlypuliacear het meest voorkomende vegetatieve aantal der chromosomen 64 bedraagt, is dit aantal hij de apogame soorten meestal veel hooger. Misschien is dit, temminste in sommige gevallen, an cene rooraforerane rerlubbeling toe te schrijven. Ten slotte kan ik er nog op wijzen, dat ook bij 
$\mathrm{W}$ ikstroemi a ind i c a apogamie is aangetnond ${ }^{1}$ ), en dat deze plant zich door een bijzonder hoog aantal chromosomen onderscheidt. Het generatieve aantal is $\mathrm{nl}$. 26, het regetatieve 52. STRASBURGER 2) telde bij twee andere geslachten van $\mathrm{Th}$ y mela eaceae, nl. Daphne en Gnidia, in de diakinese en in de kernplaat der cerste deeling in pollen-moedercellen slechts 9 paren. Ten opzichte van deze ten minste is dus het aantal der chromosomen van Wikstroemia indica meer dan dubbel zoo groot.

Het is nu echter volstrekt niet noodzakelijk, dat met apogamie steeds eene rerdubbeling van het aantal chromosomen gepaard gaat. Dit bewijzen enkele geslachten, waarin soorten met apogamie voorkomen, die zich niet door een grooter aantal chromosomen van hunne rerwanten onderscheiden of die zelfs in het oog loopend weinig chromosomen hebben.

Een goed voorbeeld hiervan geeft ons Marsilia. In dit geslacht hebben de meeste soorten eene normale generatie-wisseling en vindt men in de kernen van den gametophyt 16 , in die van den sporophyt 32 chromosomen. Bij M a rsilia D r u m mondi komt echter volgens S'TRASBURGer i) aponamire vour. Hier verloopt te sporevorming niterlijk geherel normal, mar toch heeft er geen reductie-deeling plaats. De kernen der

1) Hans Winkler. Ueber. Parthenogenesis bei Wikstroemia indica (L.) C. A. MEY., Botanische Untersuchungen aus Buitenzorg. II. 7, Ann. du jardin bot. de Buitenzorg, 2e série. vol. V, 1906, p. 208-276.

E. Strasburger. Die Apogamie von Wikstroemia indica (L.) C. A. MEx, und das Verhalten der normalgeschlechtlichen Thymeläaceen, in Histol. Beitr. Heft VII, p. 47-87. Jena, Gustav Fischer, 1909.

2) Strasburger. 1. c., p. 73 en 74 .

3) E. Strasburger. Apogamie bei Marsilia. Flora, Bd. 97, 1907, p. $123-191$. 
spore-moedercellen doorloopen wel nog de prophase dezer deeling tot na het synapsis-stadium. Maar daarna verandert de deeling weer van aard en ontbreekt het starlium der diakinese, Warrin de chromosomen grepaard aan den kernwand plegen te liggen. Deze blijven integendeel gescheiden on de decling vindt zonder reductie plaats. Het prothallium, dat uit de macrospore ontstaat, bevat dus het vegetatieve antal chromosomen, dat hier evenals bij andere soorten van Marsilia 32 is, en hetzelfde auntal wordt in het embryo aangetroffen, dat zonder bevruchting uit eene eicel met 3:2 chromosomen zijn oorsprong neemt.

Een tweede voorbeeld levert het greslacht $\mathrm{Rumex}$, warin, bij de verschillende soorten, een wisiclend aantal chromosomen wordt aangetroffen. livenwel niet zoo, dat slechts één of meer soorten dubbel zooreel chromosomen zouden hebben als de overige, maar ten deele ook in andere verhoudingen. Bij $R u m e x$ Acetos a L., R. hispanicus Koch, R. arifolius ALL. en R. n ivalis Hegetschw. vindt Roth ${ }^{1}$ ) bijv. voor het generatieve aantal 8. Bij R. scutatus L. vindt hij hiervoor 12. Bij R. A cetosella L. zijn in de diakinese 16 paren te tellen, dus is het aantal hier tweemaal zoo groot, als lij de vier eerstgenoende soorten. Rotu zeat echter, dat de chromosomen daarbij ook slechts half zoo groot zijn ${ }^{2}$ ), hetgeen het vermoeden doet ontstaan, dat de vermeerdering van hun aantal hier aan dwarsche doorsnveringen en niet aan eene overlangsche splitsing toegeschreven moet worden. Tot eene beslissing omtrent deze

1) Franz Rotir. Die Fortpflanzungsverhältnisse der Gattung Rumex. Diss. Bonn, 1907. Verh. d. Naturh. Ver. der Pr. Reinl. und Westf., 63,1906, p. 327.

2) 1. c., p. 339 . 
vraag zou men echter eerst kunnen komen door het bestudeeren van de reductie-verschijnselen van een bastaard van R. Acetosella L. met een der bovengenoemde soorten, die 8 chromosomen in hun kiemcellen voeren. In dezen bastaard zouden 12 chromosomen te verwachten zijn. Volgens FockE ${ }^{1}$ ) ontbreken echter bij de dioecische Rumex-soorten bastaarden en het is aan Roth dan ook niet mogen gelukken er een te verkrijgen. De genoemde soorten behooren alle tot de sectie A cetos a Tournef. Bij R. cordifolius, die tot de groep L a p a th u m TounNeF. behoort, trof Roтн het generatieve aantal 20 aan. Ook hier zegt hij, dat de chromosomen in verhouding tot de dikte korter zijn, dan bịj de zooeven genoemde soorten.

Bij de vijf eerste soorten nu heeft Roth apogamie aangetoond. Wanneer men rrouwelijke planten isoleert, blijkt een deel der bloemen in staat te zijn zonder bevruchting zaden te ontwikkelen. Daar juist deze soorten zich door betrekkelijk weinig chromosomen onderscheiden en zij er ook minder hebben dan andere soorten van hetzelfde geslacht, mag men aannemen, dat ook hier de apogamie niet met rene rerlubbeling van het aantal chromosomen samengaat.

Omgekeerd behoeft nu ook eene verdubbeling van het aantal chromosomen volstrekt niet met apogamie verbonden te zijn. Verschillende voorbeelden zijn te noemen van soorten, die zich door een dubbel zoo groot aantal chromosomen van nauw verwante soorten onderscheiden, en bij welke toch geen apogamie is aangetoond. Hier kan op enkele subnivale Eualchemillen worden gewezen, die normaal geslachtelijk bleven en daarbij

1) Focke. Die Pflanzenmischlinge. Berlin, 1881, p. 346. 
erenals de aporame Eualchemillen ecn verdubbeld antal chromosomen hebhen. Ėen zeer bekend voorbeceld vindt men ook bij het geslacht D rosera. Rosenbera beschrijft ${ }^{1}$ ), dat in de rustende, somatische kernen van $D$. longifolia 40, in die van D. rotundifolia slechts 20 prochromosomen ${ }^{2}$ ) zichthair zijn. Wannerr de kernen zich gaan deelen, groeien deze prochromosomen tot chromosomen aan, warvan er dus bij Drosera longifolia 40, bij 1)rosera rotumlifolia 20 in de vegetatieve deelingen optreden. Bij beide soorten vindt de reductiedeeling normaal plats. In de prophase dezer deeling is waar te nemen, dat de prochromosomen zich in paren vereenigen. Rosenberg heeft nu de meening geuit, dat de kernen van D. longifolia 2 gelijkwaardige stellen van chromosomen bevatten, maar dat daarentegen in de kernen van D. rotundifolia slechts 1 stel aanwezig is, m. a. w. dat bij D. longifolia elke erfelijke cigenschap in de kernen 4 maal vertegenwoordigd is, terwijl dat bij D. rotundifolia slechts 2 maal het geval zou zịn. IJij leidt dit nit wammmingen aan D. obovata, den bastaard van D. longifolia met D. rotundifolia, af. Bij dezen kunnen in de rustende vegetatieve kernen 30 prochromosomen geteld worden. Deze vertoonen vooral in de archespooreclien vak eeme

1) In talrijke verhaudelingen, o. a in:

O. Rosenberg. Das Verhalten der Chromosomen in einer hybriden PAanze. Ber. d. D. Bot. Ges., Bd. 21, 1903, p. 111.

O. Rosenbera. Erblichkeitsgesetze und Chromosomen. Botaniska Studier tillägnade F. R. Kjellman, Uppsala, 1906.

O. Rosenberg. Cytologische und morphologische Studien an Drosera longifolia $\times$ rotundifolia. Kgl. Srenska Vet.-Akad. Handl., Bd. 43, 1909, No. 11, p. 1-63. (Hierin eene samenvatting van do resultaten, door hem in den loop der jaren bij zijno Drosera-onderzoekingen bereikt).

3) Onder prochromosoom wordt dat deel van een chromosoom verstann, dat bij het intreden van het rust-stadium zichtbaar is gebleven. 
duidelijke rangschikking in paren en wel zoo, dat 9 of 10 paren van prochromosomen en evenzooveel geïsoleerd liggende prochromosomen waargenomen worden. Dezelfde rangschikking in paren treedt lij de reductiedeeling in de pollen-moedercellen op. In verband daarmede vindt men in de kernplaat van de heterotype deeling 10 paren van chromosomen en 10 geïsoleerde chromosomen. Bij de genoemde deeling gaan dan de 10 paren op de gewone wijze naar de polen uiteen. De 10 geisoleerde chromosomen echter gedragen zich onregelmatig. Het schijnt van het toeval af te hangen, of zij zich naar de eene of naar de andere pool begeven. Somtijds blijren er zelfs enkelen in het aequatorvlak achter. Het aantal der chromosomen in de dochterkernen is daardoor verschillend; het varieert van 11 tot 18 , maar 13 en 16 zijn de meest voorkomende aantallen.

Wanneer men nu bedenkt, dat de bastaard ontstaan moet zijn door de versmelting van eene kern van D. rotundifolia met 10 chromosomen met eene kern van D. longifolia met 20 chromosomen, dan wordt de voorstelling van Rosenberg zeer waarschijnlijk, dat de 10 paren zich vormden door het samenkomen van de 10 chromosomen van D. rotundifolia met 10 van die van D. longifolia, terwijl de 10 overige chromosomen van D. longifolia geïsoleerd bleven ${ }^{1}$ ).

Daaruit zou men kunnen besluiten tot de gelijkwaardigheid van één chromosoum ran D. rotundifolia met één chromosoom ran D. longifolia en niet met twee chromosomen van laatstgenoemde soort. Volgens deze

1) Ook wanneer de 10 paren zouden ontstaan, doordat de 20 longifoliachromosomen zich paarsgewijze tegen elkander legden, zou dat bewijzen, dat in de longifolia-kernen 2 gelijkwaardige stellen van chromosomen aanwezig zijn. 
opratting zouden in de kernen van D. longifolia twee gelijkwaardige stellen van chromosomen roorkomen, en dit zou het gevolg van rene overlangshe splitsing moeten zijn. Wanneer deze ingetreden is, moet echter in het midden crelaten worlen. Niet onwaarsehijnlijk is het, dat de besproken verdubbeling bij het ontstaan van D. Iongifolia op dezelfde wijze tot stand $\mathrm{kwam}$, als die bij het ontstaan van Oenothera gigas. Ook hier hebben wij een voorbeeld van eene soort, die niet apogatam is, en warin toch dubbel zoo veel chromosomen voorkomen, als in de naaste verwanten. Hierop zal ik echter in de laatste § van dit hoofdstuk nader ingaan.

In verband met eene opmerking van GA'TES ${ }^{1}$ ) zou hier ook nog een varen genoemi kumnen worden als voorbeeld van eene plant, die van een verdubbeld aantal chromosomen voorzien is en toch eene normale generatie-wisseling heeft.

Gates wijpst er nl. op, dat Yamanouch ${ }^{2}$ ) bij Nephrodium molle, een varen met normale generatiewisseling, 128 of 132 chromosomen in de vegetatieve kelnen heeft aangetroffen. Dit auntal is buitengewoon groot en het dubbele ran dat, hetwelk gewoonlijk bij Polypodiaceae voorkomt. Daaruit zou men het vermoeden kunnen opvatten, dat deze Nephrodium molle cen verdubbeh aantal chromosomen in zijne kernen voert. Daarbij komt nu nog, dat Yama voucul somtijds uit eene prothalliumeel zonder bevruchting een sporophyt zag ontstaan, die dus slechts 64 of 66 chromosomen in zijne kernen bevatte, evenals het prothallium zelf.

1) R. R. GATES. The stature and chromosomes of Oenothera gigas DE VRIES. Archiv für Zellforschung, Bd. 3, Heft 4, 1909, p. 546.

2) SH. Yamanodchi. Apogamy in Nephrodium. Bot. Gaz., Bd.45, 1908, p. $289-318$. 
Wanneer het juist is, dat N. molle een verdubbeld aantal chromosomen bezit, zou dit dus een terugkeer naar het oorspronkelijke aantal beteekenen. GATES zegt dan ook: ${ }^{1}$ ) This makes it probable, that a previous doubling had taken place in Nephrodium molle. This would explain, why a sporophyte can now be developed with 64 chromosomes, because it is a return to the original $2 \times$ number."

Wanneer GaTES' veronderstelling voor N. molle juist is, kan die m. i. ook tot andere soorten van varens worden uitgebreid. Bij Lastrea pseudo-mas, die eene volkomen normale generatie-wisseling heeft, is het diploide aantal der chromosomen 144, het haploide 72. Deze aantallen zijn weer buitengewoon hoog en de mogelijkheid bestaat, dat dit een gevolg van eene ververdubbeling is. Temeer daar eene variëteit bestaat, nl. Lastrea pseu-domas var. cristata apospora Druery, waarbij Farmer en DigBY ${ }^{2}$ ) slechts 60 chromosomen telden. Zij beschrijven, dat de prothalliën hier apospoor worden gevormd en dat de sporophyt daaruit apogaam ontstaat. In alle kernen, zoowel van den gametophyt als van den sporophyt, blijft het aantal chromosomen constant 60. Daar dit tevens ongeveer het bij Polypodiaceae meest voorkomende vegetatieve aantal is, zouden wij dus in deze variëteit misschien nog een voorbeeld hebben van het voorkomen van apogamie zonder verdubbeling van het aantal chromosomen.

Vatten wij het in deze $\S$ behandelde te zamen, dan kunnen wij dus drie groepen van verschijnselen naast elkander stellen:

\footnotetext{
1) 1. c., p. 546 en 547 .

2) Farmer and Digbx. Studies in Apospory and Apogamy in Ferns. Ann. of Bot., Bd. 21, 1907, p. 161-199.
} 
10. Verdubbeling van hetaantal chromosomen samengaande met apogamie.

Antennaria, Alchemilla, 'Thalictrum, Taraxacum, Rosa, Hieracium en missehien ook rerschillende varens en Wikstroemia indica.

$2^{\circ}$. Voorkomen van apogamie zonder verdubbeling van het a antal chromos 0 m e n.

Rumex, Marsilia, en misschien ook Lastrea pseudomas var. cristata apospora DrUery.

$3^{0}$. Voorkomen van een verdubbeld aantal chromosomen zonder apogamie. Eenige subnivale Eualchemillen, Drosera, Oenothera, misschien ook Nephrodium molle, Lastrea pseudo$\operatorname{mas}$ e. a. $\left.{ }^{1}\right)$.

\section{§ 2. Komt bij Spinacia apogamie voor?}

Over de vraag, of Spinacia in staat is zonder bevruchting zaden tot ontwikkeling te brengen, zijn verschillende tegrenstrijdige medterleclingen gredaan. Reerls Camerarius isoleerde vrouwelijke planten van Cannabis, Mercurialis en Spinacia en vond, dat de

$\left.{ }^{1}\right)$ Tijdens het afdrukken van dit proefschrift verscheen eene verhandeling van Strasburaer in de Jahrb. f. Wiss. Bot., Bd. 47, Heft 3, 1910, getiteld: Sexuelle und apogame Fortpflanzung bei Urticaceen. Elatostema sessile toont, ofschoon zij apogaam is, geen vermeerdering van het aantal chromosomen ten opzichte van de normaal geslachtelijke Urtica dioica. Bij beide soorten is het diploide antal 32. Dit is een getal, dat voor Dicotylen als hoog kan gelden, en de mogelijkheid bestaat, dat bij geslachtelijke soorten van Elatostema minder chromosomen zullen worden aangetroffen. Wanneer dit niet bet geval is, zou Elatostema sessile ook een voorbeeld zijn van apogamic zonder vermeerdering van het aantal chromosomen. 
eerstgenoemde wel, de beide laatste echter niet in staat waren zonder bestuiving rrucht te zetten. Daarentegen deelt A. Braun ${ }^{1}$ ) mede, dat bij Spinacia oleracea volgens Lecog, Spallanzaxi en Girod de BuzareinGES ,parthenogenese" zou voorkomen.

Is a priori iets te zeggen omtrent de waarschijnlijkheid van het voorkomen van apogamie bij Spinacia? Bij Cannabis en Mercurial is achtte Strasburger²) de kans, dat apogamie zou voorkomen, gering. In de eerste plaats, omdat deze planten eene groote hoeveelheid goed stuifmeel voortbrengen. Maar ook, omdat zoowel Cannabis als Mercurialis tot die Dicotylen behooren, welke zich door een gering aantal chromosomen kenmerken, „während doch apogame Dicotylen meist durch verhältnismäszig hohe Chromosomenzahlen ausgezeichnet sind" $\left.{ }^{3}\right)$. Bij Cannabis sativa telde StrasBURGER in de kernplaten der reductie-deeling 9 gemini, bij Nercurialis annua 7. In zijne onlangs verschenen verhandeling over "Sexuelle und apogame Fortpflanzung bei Urticaceen" laat STRASBdRgER zich ten opzichte van Urtica dioica op dezelfde wijze uit. „Die groszen Mengen Pollen, die von den männlichen Pflanzen der Urtica dioica erzeugt werden, machen von vornherein die Ooapogamie für diese Pflanzenart unwarscheinlich". Wel trof Strasburger bij Urtica dioica een belangrijk hooger aantal chromosomen aan, dan bij Cannabis en

1) A. Braur. Ueber Parthenogenesis bei Pflanzen. Abh. der K. Ak. d. W. zu Berlin, 1856, p. 316.

2) E. Strasburger. Cannabis und Mercurialis im Verdachte von "Parthenogenesis". Histol. Beitr. Heft VII, p. 22-40. Jena, Gustar Fischer, 1909.

3) 1. c., p. 34 .

4) Jahrb. f. Wiss. Bot., Bd. 47, Heft 3, 1910, p. 265. 
Mercurialis. In de diakinese waren als meest waarschijnlijk aantal 16 gemini te tellen.

Bij S pinacia nu vindt men eene zeer rijke productie van stuifmeel, terwijl ook storingen in de ontwikkeling er van, zooals die bij apogame planten zoo dikwijls worden aangetroffen, niet voorkomen. Verder is, zooals STRAsburger medegedeeld heeft, het vegetatieve antal chromosomen hier 12, het generatieve 6. Hierdoor wordt dus de waarschijnlijkheid, dat bij Spinacia apogamie zou voorkomen, gering. Toch bestond de mogelijkheid, dat misschien de eene of andere variëteit van Spinacia zich door een dubbel aantal chromosomen van de overigen zou onderscheiden en daarbij apogamie zou vertoonen. Daarom onderzocht ik le reductie-deeling in de pollenmoedercellen van de negen in het eerste hoofdstuk genoemde vormen. Bij allen bleek mij echter het vegetatieve aantal 12 voor te liomen, zoodat, wanneer apogamie bij een of meer lezer variëteiten aanwezig zou zijn, deze zeker niet met een verdubbeld aantal chromosomen zou gepaard gaan. Maar zooals o. a. de door Rotr bestudeerde soorten van Rumex toonden, is het volstrekt niet noodzakelijk, dat dit het geval is. Ik had dus rekening te houden met de mogelijkheid, dat, al was de vorming van het stuifmeel bij al de door mij onderzochte variëteiten normaal en al was het aantal der chromosomen gering, toch misschien bij één of meer der variëteiten een grooter of kleiner gedeelte der bloemen in stat zou zijn zonder bevruchting zaden tot ontwikkeling te brengen. Daarom heb ik van elk der genoemde vormen een krachtig rrouwelijk exemplaar uitgekozen, in een pot gezet, en ver van de bedden met vrouwelijke en mannelijke individuen in eene fijne gazen kooi geïsoleerd. Verder merkte ik aan deze planten 
de grens tussehen het gedeelte, waar de bloemen reeds geopend en dat, waar zij nog in knoptoestand waren. De aldus geïsoleerde individuen toonden, dat ook bij aanvankelijk gesloten bloemen de rruchtbeginsels eenigen tijd na het zichtbaar worden der stempels begonnen op te zwellen. De oorzaak darrvan was, dat in de rrouwelijke inflorescentiën hier en daar een enkele mannelijke bloem aanwezig was. Dit verschijnsel werd bij alle genoemde variëteiten, ook later op de bedden, waargenomen, bij de eene sterker dan bij de andere. Pexzig en Masters 1) vermelden slechts, dat op de vrouwelijke planten van Spinacia hermaphrodicte blocmen worden aangetroffen, ("ausnahmsweise", volgens Penzig). Bij mijne planten trof ik echter green tweeshchtige blocmen aan. Steeds waren de bloemen met meeldrarlen zuiver mannelijk, met 4 perigoonslippen en 4 meeldraden, waarvan er 2 duidelijk verder in ontwikkeling waren dan de twee overige. Het bleek dus, dat geïsoleerde vrouwelijke planten van Spinacia in staat waren zich zelf te bestuiven, dank zij het hier en daar voorkomen van eene mannelijke bloem. Dit komt overeen met hetgeen door Strasburger voor Me r c u ria lis a n $\mathrm{u} \mathrm{a}^{2}$ ) en Urtica dioica ${ }^{3}$ ) is beschreven. Bij de laatste zijn mannelijke en hermaphrorliete bloemen op vrouwelijke planten vaak aan te treffen. Bij Mercurialis annua ontstonden eerst na meer dan vijf maanden aan de geïsoleerde vrouwelijke planten hier en daar mannelijke bloemen. Tegelijk daarmee begonnen ook de vrouwelijke

2) O. Penzig, Pflanzen-Teratologie II, p. 261.

M. T. Masters, Vegetable Teratology, p. 197.

2) E. Strasburger. Das weitere Schicksal meiner isolierten weiblichen Mercurialis-annua Pfanzen. Zeitschrift für Botanik, Bd. I, Heft 8, 1909.

3) 1. c. 1910 . 
bloemen rrucht te zetten. IIier is dus het bewijs duidelijk geleverd, dat geen apogamie voorkomt, hetgeen bij Spinacia nog niet met rolkomen zekerheid te zeggen is, daar reeds in den beginne mannelijke bloemen werden waargenomen. Het is in dit geval toch mogelijk, dat tegelijkertijd apogame en hestoven bloemen vrucht zetten. Dus is het ook niet uitgesloten, dat lang's cytologischen weg aan te toonen zou zijn, dat in enkele bloemen eene ontwikkeling ran het zaal zonder bevruchting mogrelijk is. Toch is het warrschijnlijk, dat de oude mededeelingen omtrent "parthenogenese" daarop berusten, dat de onderzoekers, die er melding van maakten, cenige mannelijke bloemen op humme geïsoleerde vrouwelijke planten over het hoofd gezien hebben.

De vrouwelijke bloemen van Spinacia staan, zooals bekend is, in eene dichasiale bloeiwijze, die tot een dicht kluwen is ineengedrongen. De mannelijke bloemen, die door de vrouwelijke planten worlen voortgebracht, namen in de door mij onderzochte inflorescentiën steeds de plaats van vrouvelijke blnemen in. Zij komen zoowel op assen van hooger als van lager orde voor. Niet onmogelijk is het, dat zij ook wel accessorisch naast vrouwelijke bloemen kunnen ontstaan, ofschoon ik dit niet heb waargenomen. STRASBURGER zegt nl., dat bij Mercurialis a n nu a mamelijke bloemen ook kumnen ontstaan als seriale bijknoppen in de oksels tusschen het loofblad en de vrouwelijke bloeiwijze en ook wel tusschen de laatste en de as. Verder heeft EIcHLER ${ }^{1}$ ) bij het bestudeeren van de hloeiwijze der monoecische Atriplex litoralis en A. patula gevonden, dat het dichasium an de toppen van zijne assen uitsluitend

1) EICHLER. Blïthendiagramme, 1I, p. 83. 
mannelijke bloemen draagt, terwijl accessorisch onder de eindbloem van de hoofdas en eveneens onder die aan de assen der $1^{\mathrm{e}}, 2^{\mathrm{e}}$ en $3^{\mathrm{e}}$ orde vrouwelijke bloemen optreden.

Een belangwekkend verschijnsel, warop ik nog wil wijzen, is, dat de zaden, door geïsoleerde vrouwelijke planten tengevolge van zelfbestuiving voortgebracht, steeds bijna uitsluitend rrouwelijke planten geven. Bitter ${ }^{1}$ ) en Strasburger ${ }^{2}$ ) deden deze ervaring op met Mercurialis annua. Bij deze soort nam STrasBURGER bovendien controleproeven. Geïsoleerde vrouwelijke planten werden bestoven met stuifmeel van mannelijke individuen. Uit de zaden ontstonden ongeveer evenveel mannelijke als vrouwelijke exemplaren. Werden dergelijke geïsoleerde vrouwelijke planten bestoven met het stuifmeel, dat zij zelf in enkele mannelijke bloemen roortbrachten, dan ontstonden bijna uitsluitend vrouwelijke individuen uit de zaden; slechts een enkel mannelijk exemplaar trad op. Toch waren de omstandigheden in deze beide proeven gelijk. STRAsburger nam ook nog het volgende experiment. Geïsoleerde vrouwelijke planten werden met rreemd stuifmeel bestoven. Na het rijpen der vruchtjes werden deze weggenomen en uitgezaaid en nam hij waar, dat ongeveer evenveel mannelijke als vrouwelijke individuen ontstonden. De moederplanten werden verder geïsoleerd gehouden en brachten na eenigen tijd weer enkele mannelijke bloemen voort, waardoor zelfbestuiving intrad. De aldus gewounen zaden gaven weer uitsluitend vrouwelijke individuen. Bij Urtica dioica heeft

1) Georg Bitter. Zur Frage der Geschlechtsbestimmung von Mercurialis annua durch Isolation weiblicher. Pfanzen. Ber. d. D. Bot. Ges., 1909.

$\left.{ }^{2}\right)$ l. c. Zeitschr. f. Bot., 1909. 
STrasburger ${ }^{1}$ ) hetzelfile aangetnond. Geïsolecrle vrouwelijke individuen gaven, loor zelfhestuiving, nitsluitend vrouwelijke nakomelingen. Duze werton eveneens weïsoleerd gehouden en deden zoo eene derde generatie ontstaan, die ook geheel uit vrouwelijke individuen bestond. Deze bleken nu geen mannelijke bloemen meer voort te brengen en vermochten daardoor dan ook niet, zaden tot ontwikkeling te brengen.

Zeer watarshijnlijk is het, dat dezelfde waarneming ook bij Cannabis is gedaan. KrüGER ${ }^{2}$ ) isoleerde vrouwelijke planten van Cannabis sativa en verkreeg daarvan zaden, die eene zuiver vrouwelijke nakomelingschap gaven. Ilij meente, dat deze zarlen langs apogamen weg gevormd waren, in welk geval het inderduad niet te verwonderen zou zijn, dat er slechts vrouwelijke planten uit ontstonden. STRASBURGER is echter van oordeel, dat ook hier wel enkele mannelijke bloemen bevruchting tot stand gebracht zullen hebben. Wanneer zijne meening juist is, kan dus ook Cammbis hier als verder voorbeeld genoemd worden.

De toekomst zal moeten leeren wat de theoretische beteekenis is, die aan dit verschijnsel moet worden toegekend.

§ 3. De chromosomen van Oenothera gigas.

Een belangrijk voorbeeld van verdubbeling van het aantal chromosomen komt onder de mutanten van

1) 1. c. 1910 .

2) W. KRüGER. Ueber ungeschlechtliche Fortpflanzung und das Entstehen weiblicher Individuen durch Samen ohne Befruchtung bei Mercurialis annua und anderen diöcischen Pflanzen. Ber. d. D. Bot. Ges., 1908, p. 333. 
Oenothera Lamarckiana voor en wel bij O enothera gigas. Vooral daarom is het belangwekkend, omdat men het tijdstip kent, waarop die rerdubbeling moet zijn ingetreden. Daar voor dit geval echter eene van de andere voorbeelden afwijkende verklaring gegeven is, acht ik het wenschelijk, het hier afzonderlijk te bespreken.

Gates neemt nl. aan, dat hier de verdubbeling niet op eene mutatie berust, maar op een „incident”, en dat zij de oorzaak van de verschillen in den bouw tusschen O. gigas en O. Lamarckiana is. ${ }^{1}$ )

Gaan wij eerst de feiten na.

Blijkens de onderzoekingen van $\left(\right.$ GAtes $\left.^{2}\right)$, Miss Lutz ${ }^{3}$ ) en Geerts ${ }^{4}$ ) komen bij O. L a ma r ckia n a bij de vegetatieve deelingen 14 chromosomen voor, evenals dit bij andere soorten van dit geslacht het geval is, zooals bij O enothera biennis, waar Gates ${ }^{5}$ ) 14 chromosomen rond en O. grandiflora, waar Bradley Moore Davis ${ }^{6}$ ) tot hetzelfde resultaat kwam. Ook voor de uit $\mathrm{O}$. Lamarckiana ontstane mutanten is

1) R. R. GATES. The stature and chromosomes of Oenothera gigas DE VRies. Archiv für Zellforschung, Bd. 3, Heft 4, 1909, p. 549.

2) R. R. GATES. Hybrilization and germcells of Oenothera mutants. Bot. Gaz., Bd. 4t, p. 1-21, 1907.

3) ANNE M. LUTz. Apreliminary note on the chromosomes of Oenothera Lamarckiana and one of its mutants O.gigas. Seience, N. S., Vol, 26, p.151-152, Aug. 1907.

*) J. M. GeERTs. Ueber die Zuhl der Chromosomen von Oenothera Lamarchiana. Ber. d. D. Bot. Ges., Bd. 25, p. 191-195, 1907 en Bd. 26a, p. $608,1908$.

$\left.{ }^{5}\right)$ R. R. Gates. Further studies of Oenotheran cytology. Science, N. S., Vol. 29, p. 269, Febr. 1909.

${ }^{6}$ ) Bradlex Moore Davis. Cytological studies on Oenothera. I. Pollendevelopment of Oenothera grandiflora. Annals of Botany, Vol. XXIII, N ${ }^{0}$. XCII, October 1909. 
14 het gewone aantal. Dit telde GATes bijv. bij O.lat a 1 ), O.rubrinervis ${ }^{2}$ ), O.laevifolia ${ }^{3}$ ) en O.nanella ${ }^{4}$ ). Miss Lutz rond hetzelfde cijfer voor 0 . o b l o $\mathrm{ng}$ a, O. a l bida en O.nanell $\mathrm{a}^{5}$ ). Op dezen regel maakt nu O. gigas eene uitzondering. Deze is in 1895 als mutant in de culturen van DE VRIES opgetreden uit in 1891 door zelfbestuiving gewonnen zaad van O. Lamarckiana. Miss Lutz ${ }^{6}$ ) onderzocht de worteltoppen en rond, dat bij de vegetatieve deelingen 28 (soms ook wel 29) chromosomen aanwezig zijn, hetgeen door Gates ${ }^{2}$ ), die de pollen-moedercellen bestudeerde, bevestigd werd. O. gigas is dus van de moedersoort en de overige mutanten door een dubbel zoo groot aantal chromosomen onderscheiden.

In rijne jongste publicatie deelt $\mathrm{G}_{\Lambda \mathrm{TES}}{ }^{8}$ ) nog mede, dat de reductie-deeling bij 0 . gigas geheel normaal verloopt. Slechts kan het een enkelen keer gebeuren, dat een chromosoom zich in de spoel van de eerste deeling naar de verkeerde pool begeeft. Dit is door hem ook voor andere mutanten beschreven. Het is de vraag of eene moedercel, waarin eene dergelijke onregelmatigheid plaats grijpt, in staat zou zijn normale

2) R. R. Gates. Pollendevelopment in hybrids of 0. lata $\times 0$. Lamar chiana, and its relation to mutation. Bot. Gaz., Bd. 43, p. 81-115, 1907.

$\left.{ }^{2}\right)$ R. R. GATES. A study of reduction in Oenothera rubrinervis. Bot. Gaz., Bd. 46, p. 1-34, July, 1908.

3) R. R. Gates. 1. e., Science, Febr. 1909.

4) R. R. GAtes. The chromosomes of Oenothera. Scionce, N. S., Vol. 27, p. 193-195, Jan. 1908.

5) Anne M. Lutz. Chromosomes of the somatic cells of the Oenotheras. Scionce, N. S., Vol. 27, p. 335, Febr. 1908.

${ }^{6}$ Anne M. Lutz. l. c., Science, Aug. 1907.

7) R. R. Gıtrs. l. c., Science, Jan. 1908.

s) R. R. GATES. The stature and chromosomes of Oenothera gigas DE Tries, Archiv für Zellforschungr, Bd, 3, Heft 4, 1909. 
pollenkorrels voort te brengen. Misschien zouden deze steriel worden. Is het eerste het geval en zijn dus pollenkorrels bestaanbaar, die één chromosoom meer of minder bevatten, dan zouden daaruit misschien sommige der waargenomen afwijkingen kunnen verklaard worden. Miss Lutz ${ }^{1}$ ) telde bij enkele individuen van O. lata, O. oblonga, $\mathrm{O}$. nanella en $\mathrm{O}$. albida in de door haar onderzochte worteltoppen 15 chromosomen, dus één chromosoom meer dan gewoonlijk. Aan den anderen kant trof Gates :) onder bastaarden van 0 . lata met O. gigas eenmaal een exemplaar aan, dat 20 in plaats van de verwachte 21 chromosomen in zijne kernen voerde.

In verband met deze feiten kunnen wij ons nu de volgende drie vragen voorleggen.

$1^{\mathrm{e}}$. Hoe heeft de verdubbeling der chromosomen plaats gevonden?

$2^{\text {}}$. Waar en door welke oorzaak is zij ingetreden? Is dit gebeurd door een ,incident”, zooals Gates wil, of is het een verschijnsel van mutatie?

3e. Mag men de verschillen tusschen O.gigas en O. Lamarckiana beschouwen als gevolgen van die verdubbeling, zooals GATES meent? M. a. w. zijn in de kernen van 0 . gigas dezelfde eigenschappen vertegenwoordigd, als in die van O. Lamarckiana, alleen in dubbelen getale? Of moeten de verschillen tusschen beide soorten verklaard worden als gevolgen van dezelfde mutatie, waardoor ook de verdubbeling van het aantal chromosomen plaats greep?

Op de eerste vraag kan het antwoord kort zijn. Na wat

1) Anne M. Lutz. 1. C., Science, Febr. 1908.

$\left.{ }^{2}\right)$ R. R. Gates. The behavior of the chromosomes in Oenothera late $\times$ O. gigas. Bot. Gaz, Vol, XLVIII, No. 3, Sept. 1909. 
wij in $\$ 1$ ran dit hoofilstuk omtrent I posera longifolia hebben gezien, is het zeer waitrehijnlijk, dat ook bij O.gigas de veribubeling der chromosomen door eene lenertesplitsing ontstoml, te meer omdat GaTes ${ }^{1}$ ) beschrijft, dat er geen verschil in grootte bestait tuschen de chromosomen vano. gigas cn die van O. Lamarekiana. RosExbERg kwam bij Irosera longifolia tot dize meening door het bestudeerem der reductie-verschijnselen ran den hastaard tusschen deze plant en D. rotundifolia. Van groot belang is het dus, te weten, hoe de chromosomen zich gedragen bij de reductie-deeling van een bastaard van $O$. gigas met eene andere Oenothera-soort, dic bij de vegetatieve deelingen slechts 14 chromosomen tornt. Door Gates werd de reductie-rleeling ran planten uit de kruising O. lat a $\times \mathrm{gigas}^{2}$ ) bestudeerd ${ }^{3}$ ). Hij vond, dat bij individuen met 21 chromosomen er meestal 10 naar de eene pool en 11 naar de andere gaan, soms echter ook 9 naar de eene en 12 naar de andere. Bij het eenige individu met 20 chromosomen. uit deze liruising ontstaan, zag hij, dat elke dochterkern in den regel 10 chromosomen kreeg; soms echter kreeg de eene er 9, de andere 11 . GAtes zegt nu: The 10-11 sogregation of chromosumes in the formation of the germ cells of this hybrid shows that there is not here a pairing and separation of homologous ehromosomes of maternal and paternal origin, but that the sogregation tends to be into two numerically equal groups." Het komt mij voor, dat zijne laatste veronderstelling tot 7 ran de 21 chromosomen beperkt kan worden.

1) R. R. Gates. l. c., Bot. Gaz, Sept. 1909.

2) Urer deze bastaarden zie: Hugo DE Vraes. Bastarde ron Oenothera gigas. Ber. d. D. Bot. Ges., Bd. XXVIa, Heft 10, 1908.

$\left.{ }^{3}\right)$ R. R. Gates. 1, c., Bot. Gaz., Sopt. 1909. 
Wanneer men nl. aanneemt, analoog met hetgeen door Rosenberg voor den bastaard Drosera obovata beschreven is, dat van de 14 overige chromosomen er 7 van de moederplant 0 . lata, en 7 van den vader O. gigas afstammen, dan zouden deze 14 op de gewone wijze kunnen paren en uiteengaan. Omtrent de overblijvende 7 gigas-chromosomen zou men dan moeten aannemen, dat zij zonder paring zóó over de beide dochterkernen van de heterotype deeling verdeeld worden, dat in den regel de eene er 3 en de andere 4 krijgt. Men zou deze 7 chromosomen extra-chromosomen kumnen noemen. Zij rormen een stel, dat gelijkwaardig is met dat van de andere 7 chromosomen, die zich met de 7 lata-chromosomen paren.

Wij komen nu tot de tweede vraag: waar is de verdubbeling ingetreden en door welke oorzaak?

Twee mogelijkheden doen zich hier voor. O en othera gigas ontstond in het jaar 1891 als zaad, door bestuiving van eene eicel van 0 . Lamarckiana met eene stuifmeelkorrel van dezelfde soort. Het is nu mogelijk, dat vóór de bevruchting zoowel in de mannelijke als in de vrouwelijke geslachtskern een verdubbeld aantal chromosomen voorhanden was. Maar ook is het mogelijk dat de verdubbeling na de bevruchting intrad. Gates acht de laatste mogelijkheid de meest waarschijnlijke. Hij meent, dat kort na de berruchting, hetzij reeds in de eicel, hetzij later in het jonge embryo eene cel- en kerndeeling onvoltonid moet gebleven zijn, terwijl toch de chromosomen zich reeds in de lengte gerdeeld hadden. Daardoor zou eene plant met het dubbele aantal chromosomen ontstaan zijn. De verdubbeling beschouwt hij als cene toevallige gebeurtenis. Aan het slot van zijne 
verhandeling ') zeg't hij: "It appears to be rather of the nature of an incident among evolutionary phenomena". Dit komt mij voor eene eenigszins afwijkende voorstelling te zijn. Volgens de gangbare opvattingen toch, moet de verdubbeling van het aantal chromosomen even goed als elke andere nieuwe eigenschap van mutatieven aard zijn. Wanneer eene eicel en eene stuifmeelkorrel van O. Lamarckiana zijn samengetroffen, zal er in de bevruchte eicel geen verdubbeling van het aantal chromosomen kunnen optreden, wanneer niet minstens één der kiemcellen de eigenschap daartoe meebracht, dus gemuteerd was. Maar dan zou het meer voor de hand liggen aan te nemen, dat deze gemuteerde kiemcel zelve reeds door het muteeren het vermogen verkregen had, het aantal harer chromosomen te verdubbelen.

Het is dus het meest warschijnlijk, dat 0 . g i g a s door het samentreffen van twee kiemcellen ontstond, die beide tengevolge van een mutatieverschijnsel reeds een dubbel zoo groot aantal chromosomen in hunne kernen voerden, als zij onder gewone omstandigheden gehad zouden hebben.

Is dit in overeenkomst met de heerschende voorstellingen omtrent het ontstaan van mutanten? DE VRIES ${ }^{2}$ ) heeft als zijne meening geuit, dat aan het optreden van een mutant een mutecren van eicellen of pollenkorrels van de moederplant moet voorafgaan. En daar gemuteerde eicellen en stuifmeelkorrels blijkbaar zeer zeldzaam roorkomen is de kans, dat twee in gelijken zin gemuteerde kiemcellen elkander zullen bevruchten zoo gering, dat men daarvan in de meeste gevallen kan afzien. Hij

1) R. R. GATES. 1. c., Archiv für Zellforschung, 1909, p. 549.

2) Hugo de Yries. Die Nutationstheorie. Bd. II, 1903, p. 504. 
zegt: $\left.{ }^{1}\right)$ "Jede sichtbare Mutation muss in unsrem Beispiele somit als Bastard zwischen einer mutirten und einer nicht mutirten Sexualzelle entstanden sein, wemn wir van dem seltenen Zusammentreffen zweier mutirten Zellen absehen". Wanneer wij dit laatste echter voor ons geval niet doen en de mogelijkheid aannemen, dat hier twee in gelijken zin gemuteerde kiemcellen elkander toevallig bevrucht hebben, komt de verklaring, die boren voor het ontstaan van 0 . gigas werd gegeven, geheel met de door DE VRIEs gegeven voorstelling omtrent het ontstaan van mutanten overeen.

Gates is het hiermede echter niet eens. Hij zegt: ${ }^{2}$ ) „However this view can scarcely apply in this case, since although it is possible, that germ cells may occasinnally be produced with the unreduced number of chromosomes, fertilization with such a germ cell would produce an organism with 21 instead of 28 chromosomes. The possibilities of two such unreduced germ cells - an egg and a sperm - getting together in fertilization are very remote. Moreover no instances of this sort are known, and if this were the method of origin one would also expect to find mutants occurring with 21 chromosomes".

Hierop is in de eerste plaats te antwoorden, dat men uit eene mededeeling van GEERTS ${ }^{3}$ ) mag besluiten, dat bij O enothera Lamarckiana wel eens in de kiemcellen een verdubbeld aantal chromosomen optreedt. GEerTs deelt nl. mede, dat hij eens eene eerste deeling

\footnotetext{
1) 1. c., p. 504 .

2) 1. c., p. 544 .

3) J. M. Geerts. Beiträge zu* Kenntniss der (ytologie und der partiellen Sterilität von Oenothera Lamarckiana. Rec. des Trav. Bot. Néerl. Vol. Y, Livr. 2-4, 1909, p. 144.
} 
in eeno embryozak-mnedereel van O. Lamarekiana aantrof, niet met 14 maar met 28 chromosomen. Dat verder in de culturen ook wel mutanten met 21 chromosomen optreden, is volstrekt niet buitengesloten. O. $\mathrm{g} \mathrm{ig}$ a s is te Amsterdam nog tweemaal waargenomen, in 1898 als mutant van O. sublinearis en in 1899 uit O. lata $\times$ hirtella 1). Deze beide exemplaren waren echter steriel en droegen green zaad. Het is dus de vraag of zij werkelijk $0 . \mathrm{gigas}$ waren. Temeer daar in dien dien tijd de bastaard van $O$. gigas met $O$. Lamarckiana nog niet van $O$. gigas onderscheiden werd. Dit blijkt daaruit, dat DE $V_{\text {RIES }}^{2}$ ) $O$. Lamarckiana met $O$. gigas gekruist heeft en beschrijft daarbij slechts $U$. gigas als bastaard verkregen te hebben. Niet onmogelijk is het dus, dat de beide andere keeren, dat $O$. gigas scheen op te treden, inderdaad slechts planten ontstaan waren, die 21 chromosomen in hunne kernen voerden.

Volgens mondelinge mededeeling van Professor DE VRIES zijn derequijke vermoedelijke ", halve mutanten" (bastaarden) later wok herhaldelijk uit zuiver bestoven zaad van O. Lamarckiana ontstaan. De gelegenheid hunne chromosomen te onderzoeken heeft echter tot nu toe ontbroken.

Ten slotte valt nog te wijzen op de buitengewone zoldzatamheil, wanmede O. gigas is opectrenlen. Terwijl

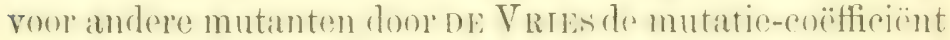
1 of 0,1 is gevonden, is die roor 0 . gigas slechts 0,01 . Ook dit pleit er m. i. voor, dat deze laatste door versmelting van twee kiemcellen ontstaan is, die ieder van cen verdubbeld aantal chromosomen voorzien waren.

1) Die Mutationstheorie. Bd. I, p. 231.

2) Die Mututionstheorie. Bd. II, p. 420. 
Gaan wij thans over tot de bespreking van de derde vraag: kunnen de verschillen tusschen 0 . gigas en O. Lamarckiana uit deze verdubbeling van het aantal chromosomen verklaard worden, m. a. w. uit eene verdubbeling van de eigenschappen, die in de kernen van O. Lamarckiana zijn rertegenwoordigd?

In zijne jongste mededeeling over dit onderwerp I) deelt Gates mede, dat de cellen van O.g i gas in alle door hem onderzochte weefsels grooter ziju, dan die van O. La marckiana in de overeenkomstige deelen. In de verschillende weefsels zijn de cellen echter in verschillende mate vergroot. Aan deze vergrooting schrijft hij de krachtigere gestalte van deze mutant toe. Bovendien vindt hij, dat de cellen van O. gig a s niet in alle richtingen gelijkmatig zijn toegenomen. Daaruit rerklaart hij de veranderingen in den vorm van bepaalde organen.

Deze vermeerderde grootte der cellen nu zou volgens zijne opratting een gevolg zijn van de rerdubbeling van het aantal der chromosomen. Hij gaat daarbij uit van de onderzoekingen van larven van zeeëgels door Boveri ${ }^{2}$ ), betreffende de rerhouding van de grootte van kernen en cellen tot het aantal der in die kernen aanwezige chromosomen. Boveri onderzocht larven, waarin slechts het generatieve aantal chromosomen voorkwam, hetzij tengerolge ran eene kunstmatige parthenogenese der eieren, hetzij door berruchting van een kernloos fragment van een ei. Verder bestudeerde hij normale larven en zulke, waarbij het aantal der

1) R. R. GATES, 1. c.

2) 'TH. Boveri. Zellenstudien V. Ueber die Abhïngigkeit der Kerngrösse und Zellenzahl der Seeigellarven von der Chromosomenzahl der Ausgangszellen. 1905. Jena. 
chromosomen was rerdubbeld, door de eieren kort na de bevruchting te schudden. Dit schudden had nl, tengevolge, dat wel de chromosomen zich deelden, maar niet te kernen. Het op deze wijze verdubbelde antal chromosomen handhaafde zich daarna bij de volgende deelingen. Boveri vond nu, dat de oppervlakte der kernen en de inhoud der cellen evenredig zijn met het aantal chromosomen. Hieruit volgt, dat bij eene vermeerdering van het aantal chromosomen de kernen sterker in grootte toenemen dan de cellen.

Dit schijnt intusschen geen algemeene regel te zijn. Want bij de geslachtelijke en de ongeslachtelijke generatiën van $\mathrm{Polysiphonia} \mathrm{violacea}{ }^{1}$ ) is geen verschil in grootte tusschen kernen of cellen op te merken, hoewel in deze de kernen 40, in gene 20 chromosomen bevatten. Misschien zouden echter toch de grootere afmetingen der cellen van 0 . gi g a s ten opzichte van die van O. Lamarckiana door de resultaten van BOVERI eene verklaring kunnen vinden. GATES gaat nu echter verder en zegt $^{2}$ ): „In $O$. gigas we have an organism built of bricks which are larger and whose relative dimensions are also altered in some cases. These two factors will apparently account for all the differences between $O$. gigas and O. Lamarckiana". En rervolgens"): "The doubling of the chromosome number in $\mathrm{O}$. gigas is to be looked upon merely as a duplication of the chromosome set already present in O. Lamarckiana. There is no evidence that any new unit characters have been added or that

1) Sh. Yamanodchi. The life history of Polysiphonia violacea. Bot. Gaz., Bd. 42, 1906, p. 401-449.

2) 1. c., p. 543 .

i) 1. c., p. 547 . 
any thing really new has come into the germ plasm". In eene noot merkt hij daarbij echter op: "The possibility must, however, be recognized, that other changes took place at the same time as the doubling of the chromosomes." Doch het is niet alleen mogelijk, dat het laatste gebeurde, maar zelfs waarschijnlijk. Het is nl. zeer moeilijk, zoo niet onmogelijk, alle verschillen tusschen $\mathrm{O}$. gi gas en $\mathrm{O}$. L a ma r c kian a te verklaren, door in de eerste slechts het dubbele van de eigenschappen van de laatste aan te nemen. Want hoe kan dit ten gevolge hebben, dat bij 0 . gigas een zoo veel grooter percentage der individuen tweejarig is, dan bij 0 . Lamarckiana? Hoe, dat de zaden van O. gigas zoo veel gemakkelijker ontkiemen, dan die van de moedersoort? Hoe de kleinere vruchten, de kortere internodiën en het opgroeien der okselknoppen aan den stengel? Hoe zou men volgens deze hypothese kunnen verklaren, dat de bladen der kiemplanten ran O. gigas rond, doch die van $\mathrm{O}$. Lamarckiana lang en toegespitst zijn, terwijl bij de kiemplanten van den bastaard tusschen deze beide planten ${ }^{1}$ ) de bladen de ronde basis van den eenen ouder en den spitsen top van den auderen hebben?

Van geheel anderen aard, maar van dezelfde strekking, is het volgende argument. GATEs beschreef, dat bij een der individuen, uit eene kruising van 0 . lata met O. gigas ontstaan, 20 chromosomen roorkwamen in plaats van 21. Hieruit volgt, dat bastaarden, die gewoonlijk 21 chromosomen bezitten, er wel eens een te weinig hebben. Denken wịj nu aan den bastaard

1) Hugo DE Vries. Bastarde von Oenothera gigas. Ber, d. D. Bot. Ges., Bd. XXV1a, Heft 10, 1908, p. 757. 
tusschen 0 . L a m a r ckian a en O. gig a s. Deze is intermediair tusschen de beide ouders en constant. Dit komt met de opvatting van Gates zeer goed overeen. Bij O. Lamarckiana komen 14 chromosomen voor, bij 0 . gigas 28, bij den bastarerd 21, dus 7 minder dam bij O. gigas. Aangezien volgens (tates het dubbele aantal chromosomen van 0 . gigas de oorzaak is van de krachtigere gestalte, moet eene vermindering van het aantal chromosomen, dat $\mathrm{O}$. gigas meer heeft dan $\mathrm{O}$. Lamiarckiani, tot de helft, ook tengevolge hebben, lat de verschillen tusschen beide soorten in den bastaard tot de helft worden teruggebracht. Maar wanneer nu ook exemplaren met 20 chromosomen voorkomen, moeten die nog meer op 0 . Lamarckiana gelijken, en zou dus een bed van den bastaard van $\mathrm{O}$. L a marckian a met $O$. gig a s geen uniform voorkomen hebben, hetgeen wel het geval is.

Zoo komen wij dus tot de conclusie, dat wel de krachtigere gestalte van 0 . gigas ten opzichte van O. Lamarckiana samenhangen kan met het verdubbelde aantal chromosomen, maar dat men desniettegenstaande niet mag aannemen, dat in de kernen der eerste slechts twee stellen van chromosomen roorkomen, die ieder gelijk zijn aan het ééne stel, dat in de kernen van O. La marckiana aanwezig is. Veelmeer moeten én de verdubbeling én de overige verschilpunten aan eene mutatic worden toegeschreven. 


\section{HOOFDST U K IV.}

\section{VEGETATIEVE DEELINGEN IN SPINACIA OLERACEA.}

\section{$\S 1$. Tweekernige cellen in wortels.}

In het algemeen schijnt het in het plantenrijk niet mogelijk, dat de vegetatieve of diploide generatie, in welke tengevolge van de bevruchting twee stellen van chromosomen in de kernen voorkomen, terwijl er in de sexueele of haploide generatie slecht één aanwezig is, met het haploide aantal chromosomen doorloopen wordt. Steeds, wanneer men meende een geval van parthenogenese gevonden te hebben, bleek het, dat in het ei, dat in staat was zich zonder bevruchting te ontwikkelen, het vegetatieve aantal chromosomen voorkwam. In de groepen der Bryophyten en Phanerogamen kent men geen, onder de Vaatkryptogamen slechts één voorbeeld van het ontstaan van een sporophyt uit eene prothalliumcel zonder bevruchting, nl. Nephrodium molle, onderzocht door Yamasouchi. ${ }^{1}$ ) Maar zooals reeds in het vorige hoofdstuk is opgemerkt, is het niet onmogelijk, dat Nephrodium molle in zijne kernen een verdubbeld aantal chromosomen voert, men zou kunnen zeggen een tetraploid ${ }^{2}$ ) aantal, en dat dus de kernen van het

$\left.{ }^{1}\right)$ Sh. Yauanodchi, Apogamy in Nephrodium. Bot. Gaz., Bd. 44, 1907.

2) E. StrasbUrger. Zeitpunkt der Bestimmung des Geschlechts, Apoyamie, Parthenogenesis und Reduktionsteilung. Hist. Beitr. Heft VII, Jena, G. Fischer, 1909, p. 109. 
prothallium met de helft daarvan toch van het diploide, aantal voorzien zijn. Wanneer daaruit dan zonder bevruchting een sporophyt ontstaat, zou dat cenvoudig een terugkeer nair liet oorspronkelijke vegetatieve anntal kunnen zijn. Daarentegen zijn in het rorige hoofdstuk verschillende voorbeelden genoemd van planten, watrin cen dubbel zoo groot aantal chromosomen anwezig is, als in de naaste verwanten, hetgeen al of niet met apogamie gepaard kan gaan. In sommige, hier niet in annmerking komende gevallen, zooals bij $\mathrm{Rumex}$, berust die verdubbeling watrschijnlijk op dwarsche doorsnoeringen der chromosomen, maar in andere, zooals bij Drosera, Oenothera en vele apogame gewassen berust zij met vrij groote zekerheid op eene overlangsehe splitsing. Tengevolge daarvan komen in het vegetatieve leven dezer laatste planten vier gelijkwaardige stellen van chromosomen voor en niet twee, zooals dat gewoonlijk het geval is, en treft men eveneens in de geslachtscellen twee dergelijke stellen aan in plaats van één. Dit laatste natuurlijk alleen, wamneer de reductie-deeling, zooals bijv. bij Oenothera gigas en Drosera longifolia, een normaal verloop heeft. In de laatste $\S$ van het vorige hoofitstuk heb ik uiteengezet, dat deze verdubbeling van mutatieven aard moet zijn, en nagegaan, wanneer zij waarschijnlijk ingetreden is. Dit bleek reeds in de kiemcellen gebeurd to mocten zijn. Deze bevatten, bijv., bij het geslacht Oenothera in het algemeen slechts één stel van 7 chromosomen, daar dit hier het gewone generatieve aantal is. Bij (). gigas moeten cr echter 14, dus 2 gelijkwaardige stellen van 7, zijn. Met gelijkwardig wordt hier berloeld, dat de beide stellen morphologisch vergelijkbaar zijn, tengerolge van de lengtesplitsing, waardoor zij ontstonden. Wanneer men 
nu echter bedenkt, dat algemeen aangenomen wordt, dat de chromosomen dragers zijn van de erfelijke eigenschappen, dan is het zeer goed mogelijk, dat de beide stellen in dit opzicht eenigszins van elkander verschillen.

In het vervolg van dit hoofdstuk zullen wij zien, dat bij vegetatieve deelingen van planten, waarin twee gelijke stellen van chromosomen in de kernen voorkomen, het ééne afkomstig van den vader, het andere van de moeder, de chromosomen meermalen in paren liggend zijn waargenomen. De vraag doet zich nu voor, of men bij planten als Oenotheragigas en Drosera $\mathrm{long}$ if olia, wanneer het juist is, dat hier vier gelijkwaardige stellen van chromosomen voorkomen, niet verwachten moet, de chromosomen bij de vegetatieve deelingen in groepen van vier te zien liggen. Om hierop een antwoord te kunnen geven, moet men deelingen bestudeeren, waarbij men zeker weet, dat vier gelijkwaardige stellen van chromosomen aanwezig zijn. Daartoe kan men de syndiploide cellen kiezen, die somwijlen onder bijzondere omstandigheden in worteltoppen gezien worden. Zij leiden er toe, de hypothese van groepen van vier chromosomen als niet noodzakelijk en onwaarschijnlijk te verwerpen.

Strasburger ${ }^{1}$ ) heeft in normale wortels van $\mathrm{P}$ is u m hier en daar zulke syndiploide cellen gezien, meestal in de buitenste lagen van den worteltop, soms ook in dieper gelegen deelen. Zij ontstaan door het achterwege blijven van een celwand, nadat eene kerndeeling heeft plaats gehad, waarna de beide zuster-kernen met elkander kunnen versmelten. Daardoor ontstaat dan eene kern

1) E. Strasburger. Ueber die Individualität der Chromosomen und die Pfropfhybridenfrage. Jahrb. f. wiss. Bot., Bd. XLIV, 1907, p. 491. 
met een verdubbeld aantal chromosomen en dus met vier gelijke stellen. De oorzaak valn dit versehijnsel is volgens de opratting ran S'TRAsBuraer gelegen in eene inwerking van storende invloeden op den wortel. 'Tot deze meening komt hij naar aanleiding van onderzoekingen van $\mathrm{NE}_{\text {EMEC }}{ }^{1}$ ) en van hemzelven ${ }^{2}$ ) over de inwerking van chloralhydraat op wortels. Laat men eene oplossing van $0,75 \%$ een uur lang inwerken op kiemwortels vian Pisum, dan blijkt, dat, ofsehoon rustende kernen daarbij onveranderd blijven, de deelingen zeor worden gestoord. Vaak wordt eene deeling beöindiend, zonder dat een nieuwe wand wordt gevormd en ontstaat er dus eene tweekernige cel. Daarin versmelten de beide kernen meestal, wamneer men de ontkiemde zaden een uur lang met water afspoelt en ze daarna weer in vochtig zaagsel plaatst. Is zulk eene tweekernige cel dicht bij de strekkingszone ontstam, dam wordt zij darin spoedig opgenomen. Is zij echter dichter bij het vegretatiepunt opgetreden, dan kan zij zich nog deelen (n eene reeks van syndiploide cellen doen ontstaan. Het is aannemelijk, dat ook in normale nict gechloralisecerde wortels door een of anderen invloed op deze wijze dubbelkernige cellen kunnen ontstaan.

Ik had de gelegenheid, ook bij Spinacia oleracea zulke syndiploide cellen waar te nemen. Evenals de Pisum-wortels, waarin STRASBURGER dit verschijnsel vond, waren de door mij bestudeerde kiemwortels in cene kas in vochtig zaagsel gegroeid. Op overlangsche doorsneden vielen dikwijls, en wel in de periphere lagen

1) B. NĚMEC. Ueber die Einvirkung des Chloralhydrats auf die Kern- und Zellteilung. Jahrb. f. wiss. Bot., Bd. 39, 1904.

3) 1. c. 
van den worteltop, rịjen van cellen door hunne bijzondere grootte op. Op eenigen afstand van het vegetatiepunt zijn onder de exodermis en om den centralen cylinder eenige lagen van groote cellen aanwezig. In deze cellen vooral, maar ook in de hier en daar dichter bij het vegetatiepunt gelegen celrecksen, treft men dikwijls twee kernen aan, of één kern, die door hare bijzondere grootte uitmunt, of ook wel meerdere kleine kernen.

Fig. 24, Pl. III toont eene dergelijke reeks van cellen, die dicht bij het vegetatiepunt van den wortel lag. Onderaan ziet men eene cel, waarin twee kernen dicht tegen elkander gedrukt, maar duidelijk gescheiden, liggen. In de cel daarboven is eene spoel zichtbaar, die, ten opzichte van de spoelen in de naburige cellen, van dubbele grootte was. Ook valt op, dat deze spoel meer afgerond is, terwijl de polen van normale spoelen meer toegespitst zijn. Ook van terzijde kan men reeds opmerken, dat hier in de kernplaat dubbel zoo veel chromosomen aanwezig zijn, als gewoonlijk bij de vegretatieve deelingen. In de volgende cel ziet men, hoe twee kernen met elkander versmelten en hoe daaibij ook de twee nucleolen incensmelten. In de bovenste cel der nroej is eene kern afgebeeld, die duidelijk veel grooter was, dan die der naburige cellen. De meerdere grootte van kernen en cellen in deze syndiploide celreeksen kan als een argument worden beschouwd voor den door Boveri opgestelden regel, waarvan in het rorige hoofdstuk sprake was. De deelingsverschijnselen, die ik hierbij waarnam, stemmen overeen met die, welke STRASBURGER in met chloralhydraat behandelde wortels heschrijft. Aan de polen van de breede spoel, die optreedt, wanneer eene syndiploide kern zich deelt, kunnen weer syndiploide kernen ontstaan. Maar evenzeer kan het 
gebeuren, dat aan een der polen bijv. twee diploide in plaats van één syndiploide optreden of zelfs meerdere kleine kernen of één diploide kern en eenige kleinere. Daardoor is het te verklaren, dat in de cellen van dergelijke syndiploide reeksen nu eens één groote kern, dim eens twee kernen, die de gedaante hebben van die van normale wortelcellen, en dan weer complexen van vele kleine kerntjes optreden. In alle cellen maakt zich voorts een streven kenbaar de kleinere kernen tot een syndiploide te doen ineensmelten.

Bestudeert men nu dwarsehe doorsneden van dergelijke wortels, dan ziet men in de normale cellen de chromosomen dikwijls duidelijk gepaard in de kernplaten liggren. Bij Spinacia vindt men 6 zulke paren. In tal van cellen kan men echter syndiploide kernplaten aantreffen, waarin dus een dubbel zoo groot aantal, nl. 24, chromosomen, aanwezig is. Dit blijkt ten duidelijkste

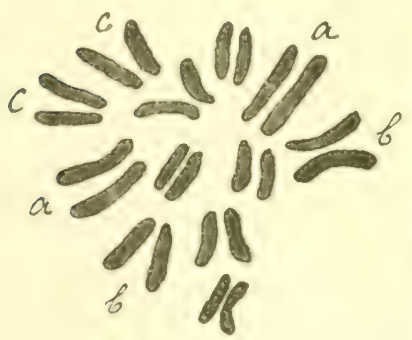

list. A.

Symdiploide kernplat uit een wortel van Spinacia olerarea $(\times 2250)$. 'Twee gelijkwaardige stellen van 6 paar chromosomen zijn aanwezig. uit figuur A, die eene syndiploide kernplaat bij 2250-malige vergrooting weergeeft. De teekening is met het teckenapparaat vervaardigd, zuiver natuurgetrouw en niet geschematiseerd. Buitengewoon fraai komt hierin wit, lat de chromosomen in paren liegen. (troepen van vier worden echter niet waargenomen. De vier homologe chromosomen van elk type, die in deze kernen aanwezig zijn, blijven dus in twee groepen van twee liggen en deze naderen niet tot elkander, om dubbele paren to vormen. Dank zij de lengteverschillen tusschen de chromosomen kan men echter wel in de kernplaat 
met eenige zekerheid nitmaken, welke twee paren telkens bij elkander behooren. In dezelfde doorsnede, waarin de afgebeelde kernplaat lag, merkte ik nog een dergelijke op, waarvan alle chromosomen zich duirlelijk in twee overlangsche helften hadden gesplitst, die bezig waren uiteen te gaan. Dit gaf den schijn van eene kernplaat met 48 chromosomen.

In alle opzichten bevestigen inijne waarnemingen aan normale wortels van Spinacia, hetgeen STRASBURGER op dwarsche doorsneden van gechloraliseerde wortels van Pisum heeft gezien. Hier komen in de normale cellen 7 paren in de kernplaten voor, in de syndiploide 14. Groepen van vier komen volgens StrasburGER ook hicr niet voor, tenzij toevallig twee paren tot chanrler zijn granadert. Dit gaf aan STRASBURGER aanleiding, om te zeggen: ${ }^{1}$ ) „Durch die Vereinigung der beiden elterlichen Chromosomen sind augenscheinlich die durch ihre Homologie veranlaszten Anziehungen in dip̧loirlen Kermen ansgeglichen, und es bleibt keine ungesättiste Affinität übrig, um die homologen Paare von zwei diploiden Kernen zusammenzuführen".

Ten opzichte van de boven besproken kernen van Diosera longifolia, Oenothera gigas en vele der apogame gewassen kan men dus uit het bovenstande de gevolgtrekking maken, dat men tegen de opvatting, dat hicr vier stellen van chromosomen aanwezig zijn, zooals er in de kernen van andere planten twee zijn, niet als argument kan aanvoeren, dat bij de kerndeelingen rezer planten de chromosomen niet in groepen van vier liggen.

Behalve bij Spinacia heb ik ook in wortels van

1) 1. c. p. 494 . 
andere planten somtijds in de periphere lagen van cellen twee grootere kernen of meerdere kleine in eene cel opgemerkt. Misschien is dus het optreden van syndiploide cellen in wortels cen verschijusel van meer algemeenen aard.

\section{§2. De paring der chromosomen.}

In de vorige paragraaf heb ik er op gewezen, dat meermalen warrgenomen is, dat in diploide kernen de chromosomen gepaard liggen. Bij botanische objecten is dit het eerst aan Strasburger ${ }^{1}$ ) opgevallen. In de prophasen van weefselkernen van Galtonia en Funki a zag hij, dat de chromosomen, die hier sterk in grootte van elkander verschillen, in paren an den kernwand liggen. Eveneens zag hij zulke paren in de kernplaten. Reeds vroeger was hetzelfde verschijnsel door GuIGNARD in teekening gebracht, zonder dat hij daaraan eene bijzondere beteekenis toekende. In eene kernplaat van een bevrucht ei van $\mathrm{Naj}$ a s m a jo r beeldt hij $\mathrm{nl} .6$ in grootte verschillende paren van chromosomen af ${ }^{2}$ ). Nadat Strasburger eenmaal op het verschijnsel had gewezen, zijn herhaaldelijk bij vegetatieve deelingen paren van chromosomen gezien. Door StrRasburger zelven bijv. bij $\mathrm{P}$ is $\mathrm{u} \mathrm{m}^{3}$ ), waar hij, zooals reeds is medegedeeld, 7 paren in de kernplaten telde, en bij Lili u m ${ }^{4}$ ), waar het in het algemeen moeilijk is, om

1) E. Strasburaer. Typische und allotypische Kernteilung. Jahrb.f. wiss. Bot., Bd. XLII, p. 19, 1905.

2) M. L. Guignard. La double fécondation dans le Najas major. Journ. de Bot. Bd. XV, 1901.

3) E. Strasburaer. Ueber die Individualitit der Chromosomen und die Pfropfhybridenfraye. Jahrb. f. wiss. Bot., Bd. XLIV, 1907.

4) E. Strasburger. Chromosomenzahlen, Plasmastructuren, Vererbungsträger und Reduktionsteiling. Jahrb. fo wiss. Bot., Bd. XLV, 1908. 
de paren waar te nemen, daar de chromosomen zeer lang zijn en geen noemenswaardig verschil in hunne. lengte vertoonen.

Verder heeft GEERTS ') opgemerkt, dat re 14 chromosomen, die in de kernplaten der regetatieve deelingen van $\mathrm{O}$ enothera $\mathrm{L}$ a marckiana geteld kunnen worden, min of meer duidelijk in 7 paren gerangschikt zijn. Bijzonder fraaie paren heeft MüLLER ${ }^{2}$ ) bij regetatieve deelingen in worteltoppen van verschillende soorten van Y u c c a waargenomen. De 10 groote en 44 tot 46 kleine chromosomen, die hier aanwezig zijn, vormden zoowel in de kernplaten als ook nog bij het uiteengaan der dochterchromosomen naar de polen, zoo duidelijke paren, dat de praeparaten zich tot photographische opnamen leenden. Volgens StTRasburger is deze paring een lkrachtig argument voor de individualiteit der chromosomen en moet men zich voorstellen, dat van ieder paar het eene lid afkomstig is van den vader, het andere van de moeder. Hij zegt ook "): "Ich zweifle nicht im geringsten daran, dass es sich um eine allgemeine Erscheinung in diploiden Kernen dabei handelt".

Dit neemt echter niet weg, dat een rerschijnsel waaraan zon belangrijke theoretische beschouwingen zijn vast te knoopen, door herhaalde waarnemingen aan verschillende objecten behoort te worden bevestigd. Vooral is dit hier het geval, waar het aantal waarnemingen nog zoo klein is.

1) J. M. GEERTS. Beiträge zur Kenntniss der. Cytologie und der partiellen Sterilitüt von Oenothera Lamarckiana. Rec. des trav. bot. Néerl. Vol.V,1909.

2) Clexexs MüLLER. Ueber karyokinetische Bilder in den Wurzelspitzen von Yucca. Jahrb, f, wiss, Bot., Bd. XLVII, Heft I, 1909.

3) E. Strasburger. Zeitpunkt der Bestimmung des Geschlechts, Apogamie, Parthenogenesis und Reduktionsteilung. Hist. Beitr. Heft VII, Jena, G. Fischer, 1909, p. 90. 
In de vorige paragraaf wees ik er reeds op, dat ook bij Spinacia oleracea de chromosomen in de kernplaten duidelijk gepaard liggen en gaf ik eene afbechling van eene syndiploide kernpliat uit een wortel, waarin zonder den minsten twijfel de '4 chromosomen in 12 paren gerangschikt zijn. Naar ook in de normale diploide kernplaten, zooals er cen in fig. B. is afgebeeld,

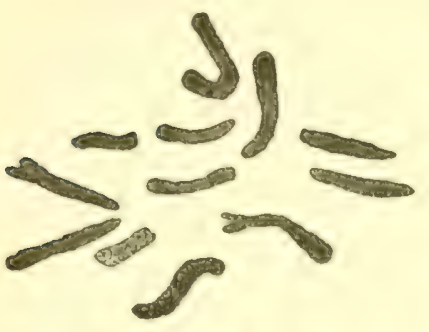

FIG. B.

Normale kernplaat uit een wortel van Spinacir oleracea $(\times 2250)$.

De 12 chromosomen liggen in 6 paren. valt terstond in het $00 \mathrm{~g}$, dat de 12 chromosomen in 6 paren gelegen zijn. Dezelfde verschillen in lengte, die in fig. A. op te merken vielen, zijn ook hier weer te zien. In de linkerhelft van de figuur schijnen de leden van één der kleine paren door een lang paar gescheiden te zijn. Dit is in werkelijkheid niet het geval, dar het onderste kleine chromosom van de figuur lager lag, dan het lange paar er boven, hetgeen dan ook door eene lichtere tint is aangeduid. Enkele chromosomen vertoonen duidelijk een gevorkt uiteinde, daar de beide lengtehelften op het punt staan naar de polen uiteen te gaan. Opmerking verdient nog, dat de kernplaat van fig. B. mot dezelffle vergronting geteekend is, als die in fig. A. Men ziet, dat de chromosomen in fig. B. iets forscher zijn, dan die in fig. A. Daarmee is echter volstrekt niet gezegrl, dat steeds de chromosomen in syndiploide cellen kleiner zijn, dan in normale. In eene cel naast die, waarin de afgebeelde syndiploide kernplaat lag, zag ik eene andere, waarvan de chromosomen duidelijk gronter waren. Daaruit blijkt, dat de chromusomen in verschillende cellen eene 
meer of minder krachtige gestalte kunnen aannemen.

Spinacia oleracea kan dus als een nieuw voorbeeld voor het bestaan van lengteverschillen tusschen de chromosomen en voor hunne ligging in paren in de kernplaten genoemd worden.

Evenals Strasburger dit voor Galto nia en Funkia, GeErts voor O e n o th e ra, MüLler voor Yucca beschreef, kan men ook bij Spinacia waarnemen, dat reeds in de prophase, wanneer de chromosomen nog tegen den kernwand liggen, de paren duidelijk zijn. Een reel belangrijker vraag, die zich nu voordoet, is echter, of de chromosomen ook op nog vroeger stadiën, in de nog rustende kernen, paarsgewijze naast elkander liggen. Deze vraag is vooral gewichtig met het $00 \mathrm{~g}$ op een juist inzicht in de verschijnselen der reductiedeeling.

MüLLER ') deelt daaromtrent mede, dat, wanneer in worteltoppen van $\mathrm{Y} \mathrm{u} \mathrm{c} \mathrm{ca} \mathrm{eene} \mathrm{kern} \mathrm{zich} \mathrm{gaat} \mathrm{deelen,}$ de paarsgewịze rangschikking der chromosomen steeds duidelijk voor den lag komt, zoodra zij uit het netwerk van de rustende kern te voorschijn komen. Daarbij zijn de einden der chromosomen steeds van den beginne af vrij. Aan het einde van eene deeling worden de chromosomen bij het intreden van den rusttoestand weer netvormig. Ook daarbij blijft nog de paarsgewijze rangschikking op te merken, hetgeen daardoor gemakkelijk wordt gemaakt, dat de vele kleine chromosomen zich bij de deeling het eerst naar de polen begeven en dat de 10 groote volgen. Deze ziet men dan dikwijls in de naar de kernplaat gekeerde zijde van de dochterkern in paren liggen.

1) 1. $\mathrm{c}$, 
Spinacia is voor het bestudeeren dezer vroege prophasen en late telophasen op verre na niet zoo geschikt als $\mathrm{Y}$ u c c a. T'en eerste zijn de kernen zeer reel kleiner, maar verder komen tusschen de chromosomen geen zoo groote verschillen in lengte voor, en dit bemoeilijkt wit den arre der zaak het beoordeelen der paarscrewijze lioging. Toch nam ik een verschijnsel waar, dat er voor pleit, dat ook bij Spinacia de chromosomen in den rusttoestand paarsgewijze naast elkander liggen. Dit verschijnsel is ontleend aan wat er bij den overgang van den rusttoestand in de prophase plaats vindt.

In de prophase van eene deeling zwelt nl. de kern op en zag ik de chromosomen reeds vroeg in 6 paren aan den kernwand geplaatst. Van een doorloopenden kerndraad was nooit iets te zien. De beide componenten van een paar hadden steeds ieder van den beginne af twore rije uitoinden. Somwijlon lonft men mu te grelegenheid waal te nemen, dat bijv in een der paren een gedeelte der chromosomen $n o g$ niet ilen staafvorm heeft bereikt, maar nog netvormig is. Deze netvormige gedeelten der beide chromosomen van een paar ligyen dan parallel met elkander en dit pleit er dus voor, dat de paren ook in den rusttoestand reeds bestaan.

Bij het einde van eene deeling groepeeren de chromosomen zich in een dicht kluwen aan de polen van de spoel. Door het gemis aan belangrijke lengteverschillen kan men thans niet zien, dat zij in paren netvormig worden. Daarvoor zijn de prophasen dus veel gunstiger.

In dit opzicht is ook het bestudeeren der zoogenoemde prochromosomen van groot gewicht. Dikwijls worden de chromosmmen bij het intrerien van 
den rusttoestand tot een zoo fijn netwerk, dat men er met de sterkste vergrootingen niet veel meer van kan zien; dit is ook bij S p in a c i a zoo. Bij vele planten echter blijft zelfs in kernen, die zich niet meer deelen, een bepaald gedeelte van het chromosoom als chromatine-korrel aan den kernwand zichtbaar. Vroeger droegen deze korrels den naam pseudonucleolen.

Rosenberg ${ }^{\text {l) }}$ ontdekte echter, dat deze lichamen in de rustende kernen van verschillende planten in een bepaald aantal optreden, en dat dit met dat der chromosomen orereenstemt. Dit deed de meening ontstaan, dat men in deze chromatine-lichamen deelen van de chromosomen had te zien.

Later heeft OverToN ${ }^{2}$ ) ze met den naam prochromosomen bestempeld.

LAIBACH ${ }^{3}$ ) bestudeerde het voorkomen van deze prochromosomen bij Cruciferen. Ook hij nam waar, dat zij in het kernnet optreden in een aantal, dat met dat der chromosomen overeenstemt. Dikwijls waren deze prochromosumen van verschillende grootte, hetgeen volgens hem daarop berust, „dass der Grad der Verteilung des Chromatins auf das Netzwerk nicht für alle Chromosomen eines Kermes der gleiche zu sein braucht". Door LAIBACH werd ook beschreven, dat de prochromosomen in paren kunnen liggen. Hierop legt RosexBERG nu ook den nadruk in eene voor korten tijd verschenen verhandeling "Ueber den Bau des Ruhekerns". ")

1) O. Rosenberg. Ueber die Individualität der Chromosomen im Pfanzenreiche. Flora XCII, 1904.

2) J. B. Overton. Ueber Reduktionsteilung in den Pollenmutterzellen einiger Dikotylen. Jahrb. f. wiss. Bot., Bd. XLII, 1905.

3) F. Laiвасн. Zur. Frage nach der. Individualität der Chromosomen im Pflanzenreich. Beih. z. Bot. Centr.bl., Bd. XXII, 1907.

$\left.{ }^{4}\right)$ Svensk botanisk Tidskrift, Bd. III, 1909, p. 163-173. 
In de tentakels van Drosera komen onder normale omstandigheden aan den wand der kernen een aantal frochromosomen vour, overecnstemmend met het aantal der latere chromosomen. Wanneer men de tentakels prikkelt, worden de prochromosomen grooter en zwellen aan tot chromosomen. Daar de ophooping van het chromatine van de prochromosomen uitgaat, kan men deze niet voor toevallige chromatine-massa's houden. RoswiBERG toonde verder het voorkomen van deze lichamen nog in cen 40-tal soorten uit verschillende familiën aan. Zeer dikwijls rond hij ze in rustende kernen van volwassen organen, die zich dus niet meer deelen.

Rosexberg merkit nu echter, meer in het bijzonder voor de tentakels van Drosera, op, dat deze prochromosomen dikwijls in paren liggen. Hij gelooft niet, dat men deze paren kan opratten als de producten van de lengtesplitsing van een prochromosoom en zegt dus: „wenn meine Deutung der genamnten Erscheinung in den Tentakel-Kernen richtig ist, so ist man, scheint es mir, zu dem Schlusz berechtigt, dass die Chromosomen auch im Ruhestadium des Kerns zu Paaren angeordnet sind".

Dit is zooals boven reeds werd aangeduid een belangrijk punt: wanneer toch in de diploide kernen de chromosomen in den rusttoestand paarsgewijze naast elkander liggen, zal dat met de meeste wararshijnlijkheid ook in de moedercellen van stuifineelkorrels en embryozakken het greval zijn. Hiermede moet dus bij het bestudeeren der reductie-verschijnselen rekening worden gehouden.

Resumeerende kunnen wij dus zeggen, dat uit verschillende objecten, ook uit wortels van Spinacia, gebleken is, dat de chromosomen in de vegetatieve gene- 
ratie, zoowel in kernplaten als in pro- en anaphasen in paren liggen, hetgeen zeer voor hunne individialiteit pleit. Als argument hiervoor kan mede worden genoemd, dat lengteverschillen tusschen de chromosomen van generatie op generatie en bij de verschillende kerndeelingen steeds gehandhaafd blijven. Ook dit is bij Spinacia zichtbaar. Ten slotte hebben wij gezien, dat ook in den rusttoestand der kernen de chromosomen gepaard zijn. Dit bleek uit de waarnemingen, die door MüLLER bij Yucca zijn gedaan, uit de verschijnselen, die zich in de prophasen der deelingen in de wortels van Spinacia voordoen, en eveneens uit de studie der z. g. prochromosomen.

\section{§ 3. De overlangsche splitsing der chromosomen.}

Een enkele opmerking moge nog gemaakt worden over de overlangsche splitsing der chromosomen. Zooals bekend is, stelt GRÉGOIRE ${ }^{1}$ ) zich roor, dat een chromosoom een band is, die uit twee stoffen bestaat, eene achromatische grondsubstantie en eene chromatische stof, die de eerste impregneert. Wanneer een chromosoom zich gaat deelen, treden in dien band eene reeks van openingen op, alveolen, door welke ten laatste de eerst homogene band in twee smallere wordt verdeeld. Deze

1) V. GRÉGOIRE et A. Wijgaerts. La reconstitution du noyau et la formation des chromosomes dans les cinèses somatiques, I. Racines de Trillium grandiflorum et télophase homoeotypique dans le Trillium cernuım. La Cellule, Bd. XXI, 1903.

V. GrÉgoIre. La structure de l'élément chromosomique au repos et en division dans les cellules végétales (Racines d'Allium). La Cellule Bd. XXIII, 1906. 
splitsing treert steeds op in de prophase en kan zelfs reeds plaats hebben, wanneer de chromosomen nog eenigszins netrormig zijn. GrÉGOIRE ziet daarbij noch bij Trillium, noch bij Allium eenig spoor van de chromatine-schijren, die voor zooveel botanische en zoologische objecten waren beschreven en komt er dus toe, het bestaan van chromomeren te ontkennen. Wanneer men op een ongedeeld chromosoom lichtere en donkere plekken ziet, is dit volgens hem een gevolg daarvan, dat in den homogenen band alveolen aanwezig zijn, waardoor de deelen van het chromosoom tusschen die alveolen den indruk van schijven maken. STRASBURGER meent, dat toch chromatine-schijven aanwezig zijn, en geeft in rijne rerhandeling „Ueber die Individualität der Chromosomen und die Pfropfhybridenfrage", 1) eenige afbeeldingen van chromosomen uit wortelkernen van $\mathrm{P}$ is um, die op het punt staan zich te deelen. Deze chromosomen vertoonen inderdaad duidelijk donkere chromatine-schijven en daartusschen lichtere plekken. Naar aanleiding hiervan zeg't STrasburger, ") „Vielmehr stelle ich mir das Chromosom als Lininstrang vor, in welchem sich die Einsehlüsse so verschieben können, wie die Nikrosomen in einem Hyaloplasmastrang des Cytoplasma". Deze meening worlt ook door GRÉGOIRE gedeeld. Deze immers stelt zich voor, dat een chromosoom bestaat uit eene achromatische stof en eene chromatische, die de eerste impregneert en zich hier en daar in bepaalde deelen daarvan kim ophoopen, terwijl zij andere gedeelten verlaat. STRAsBukgkr beweert nu niet, dat de chromatische substantie de stof zou zijn, waaraan

1) Jahrb. f. wiss. Bot., Bd. XLIV, 1907.

2) 1. c., p. 516 . 
de erfelijke eigenschappen zijn gebonden. ${ }^{1}$ ) Wel meent hij, dat, wanneer een chromosoom zich gaat deelen, zoowel de dragers der erfelijke eigenschappen, als de chromatische stof, zich hier en daar in het chromosoom ophoopen, waardoor de chromomeren (waarvoor door hem ook het woord Iden wordt aangewend) ontstaan. Hij zegt: ${ }^{2}$ ) ,Während die Pangenosomen zu Iden zusammentreten, zieht in letztere auch die färbbare Substanz hinein, was veranlaszt, das zwischen den stark tingierbaren Chromatinscheiben die hellen Lininbrücken sichtbar werden". Wanneer men nu de figuren beziet, die Strasburger daarran bij Pisum geeft, dan kan men echter, zooals rooral uit figuur 38 op plaat VII blijkt, GRÉGOIRE gelijk geven, waar hij de lichtere plekken aan de aanwezigheid ran alreolen toeschrijft, die tot stand zullen brengen, dat het chromosoom zich in de lengte splitst. Grégoire en Strasberger zien hier, naar ik meen hetzelfde, maar geven aan wat zij zien eene verschillende uitlegging.

Als echter de deeling heeft plaats gehad, zijn er volgens GRÉGOIRE twee homogene banden en volgens Strasburger twee banden, die elk uit eene rij ran chromatine-schijven met linine-intervallen bestaan. De afbeeldingen, die GréGorre van Trillium en Allium geeft, bewijzen inderdaad, dat hier na de deeling geen chromatine-schijven zichtbaar zijn. Daartegenover toonen de figuren 39 en 40 op plaat VII van

1) Enzio Redter nam bij Pediculopsis graminum chromosomen zonder chromatine waar. (Enzio ReUTER. Merokinesis, ein neuer Kernteilungsmodus. Acta societatis scientiarum Fennicae, Tom. XXXVII, No. 7, Helsingfors, 1909).

$\left.{ }^{2}\right)$ Typische und allotypische Kernteilung.Jahrb. f. wiss. Bot., Bd. XLII, 1906, p. 33. 
Strasburger zeer duidelijk, dat zij bij P is u m wel waimeembair zijn. I)it doet STrasburaki ammemen, dat chromomeren wel algemeen voorkomen, maar dat zij onder bepaalile omstandigheden niet waanneembanr zijn. Hij zegt: ${ }^{1}$ ) „Es kann ein Chromosom so viel färbbare Substanz führen, dass diese alle besonderen Terteihungen seiner Einschlüsse unkenntlich macht, dann wird sich ein solches Chromosom bei der Längsteilung wie ein scheinbar homogenes Band spalten. Das ist aber sicherlich auch in der regetativen Sphäre nicht immer der Fall". Na de deeling breidt zich volgens hem bij Pisum en andere planten, watarbij de chromomeren duidelijk zijn, de chromatische stof weer over het geheele dochter-chromosoom uit, waardoor datrin na eenigen tijd geen chromatine-schijven meer zijn op te merken.

Ten einde over dit punt tot klaarheid te komen, lette ik bij Spinacia in het bijzonder op den bouw der chromosomen in de vroege prophasen van de vegetatieve deelingen. Het komt mij vool, dat hetgeen ik bij Spinacia waarnam het midden houdt tusschen hetgeen door Grégorre voor A lli u m en 'I' rilli u m en wat door Strasburger o. a. voor $\mathrm{P}$ is u m is beschreven. Terwijl in de prophase de chromosomen nog aan den kernwand liggen, ziet men er op regelmatige afstanden lichte plekken in verschijnen. Deze kunnen geen linine-intervallen zijn, waaruit de chromatische stof zich naar amgrenzende deelen van het chromosoom heeft begeren, maar wel, zooals Grígorre meent, openingen of alveolen, die de deeling van het chromosoom zullen bewerken. Wanneer nu dit laatste

\footnotetext{
$\left.{ }^{1}\right)$ l. c. p. 516.
} 
overlangs gesplitst is, zie ik bij $\mathrm{Sp}$ in a cia twee banden, die in een spiraal om elkaar zijn gewonden en die niet homogeen gekleurd zijn, maar eene afwisseling van donkere en lichtere plekken vertoonen, echter op verre na niet zoo sterk, als STRASBURGER dit voor $\mathrm{P}$ is u m heeft afgebeeld. Hoe kan men nu verklaren, dat in het eene geval de beide overlangsche helften van een chromosoom geheel homogeen zijn gekleurd, terwijl in het andere meer of minder duidelijk donkere chromatine-schijven met lichtgekleurde linine-intervallen worden waargenomen? Ik zou hier behalve op eene verschillende hoeveelheid chromatische stof, zooals STRAsburger meent, vooral den nadruk willen leggen op de breedte van het zich deelende chromosoom.

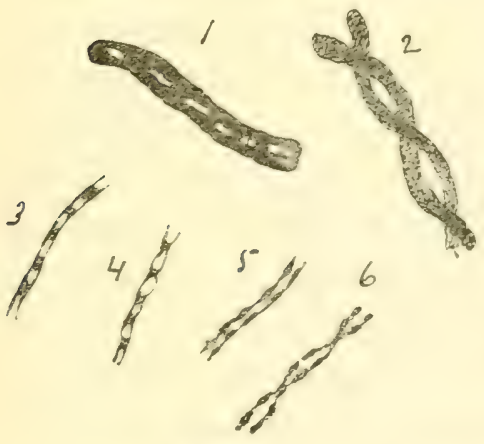

Fig. C.

Schematische roorstelling van de splitsing van een breed ( 1 en 2 )

en ran een smal chromosoom (3 tot 6.)

Is een chromosoom breed, (Fig. C, 1 en 2) zooals bij Trillium en Allium, dan zal men, wanneer hierin eene reeks van alveolen optreedt, niet zoo sterk den indruk krijgen ran schijven met helder gekleurde tusschenruimten en zullen ook de overlangsche helften meer het voorkomen van een homogenen band hebben. Is het chromosoom smal, (Fig. C, 3-6) zooals bij Pis u m en in iets mindere mate ook bij Spinacia, dan zal, bij het ontstaan en het aangroeien van eene alveole in het chromosoom, de er naast gelegen stof naar de ruimten tusschen twee alveolen gedrongen worden. Daardoor zullen dan duidelijke 
chromomeren aanwezig schijnen te zijn. Deelt zulk een chromosoom zich nu, dan zullen de verdichte plekken natuurlijk ook dikkere plaatsen op de dochter-chromosomen teweeg brengen, die, zooals men dit steeds opmerkt, in de beide lengte-helften tegrenover elkander zullen liggen. De plekken, waar in het moeder-chromosoom de alveolen lagen en waar dus weinig substantie in het chromosoom aanwezig was, geven dan ook dunnere plaatsen tusschen de chromomeren van het dochterchromosoom. Deze plekken verdwijnen eenigen tijd na de deeling en de dochter-chromosomen nemen een homoggeen uiterlijk aan. Dit blijft zoo tot aan het stadium der kernplaat, waarin zij dicht tegen elkander blijven liggen, zoodat men aanvankelijk zelfs niet kan zien, dat de chromosomen der kernplaat uit twee helften bestaan.

Ik kom dus tot de conclusie, dat wanneer bij deelingen chromomeren optreden, dit een mechanisch verschijnsel is, afhangende van de hoeveelheid chromatische stof en vooral van de breedte der chromosomen en niet, zooals algemeen wordt aangenomen, een streven van de stoffelijke dragers der erfelijkheid, om zich met het $00 \mathrm{~g}$ op de deeling, die plaats moet hebben, tot grootere eenheden, chromomeren, te vereenigen. 


\section{HOOFDSTUK V.}

\section{DE REDUCTIE-DEELING BIJ SPINACIA OLERACEA.}

\section{§ 1. Historisch overzicht.}

Omtrent de vraag, hoe de reductie-deeling in spore-, pollen- en embryozak-moedercellen verloopt, zijn de verschillende onderzoekers nog niet tot overeenstemming gekomen. In het algemeen is men het er wel over eens, dat de eerste deeling de vermindering van het aantal chromosomen tot de helft te weeg brengt en dat daarbij de beile in het vegetatieve leven aanwezige stellen van chromosomen, waarvan het eene van de moeder en het andere van den vader afkomstig is, uiteengaan. Maar, zooals ik reeds in de inleiding heb opgemerkt, bestaat er nog geen zekerheid over de wijze waarop de paren der diakinese tot stand komen. Hebben de twee chromosomen, die zulk een paar vormen, gedurende de geheele prophase der reductie-deeling naast elkander gelegen? Of lagen zij achter elkander en worden zij eerst korten tijd vóór de diakinese naast elkaar geplaatst? Hierover loopen de meeningen uiteen. Zelfs waar verschillende onderzoekers eenzelfde object bestudeerden, bleef ieder bij zijn eigen meening.

Omstreeks het jaar 1900 verschenen rlvic vorhantelingon. 
van Gujgrard ${ }^{1}$ ) over Najas, van Grégome ${ }^{2}$ orer Lilialceae en van STRAsBURGER ${ }^{3}$ ) over rerschillende gewassen, waarin werd uiteengezet, hoe de deeling in de moedercellen plaats grijpt. Toen meende men algemeen, dat de chromosomen in een kerndraad achter elkander waren gerangschikt. De genoemde geleerden beschreven nu, dat deze kerndraad in de lengte werd gesplitst en daarna in een generatief aantal leden werd gesegmenteerd. Bij de cerste deeling gingen de helften ram elk dezer leden naar de polen uiteen, waarbij zij eene tweede overlangsche splitsing vertoonden. Dat de deeling op deze wijze gesehiedt, wordt thans nog door de meeste onderzoekers aangenomen. Eehter met dit verschil, dat men thans aamneemt, dat er niet één doorloopende kerndraad aanwezig is en dat de rroegere eerste lengtesplitsing geen eigenlijke splitsing is, maar een gevolg daarvan, dat de chromosomen in de vroege prophase van de reductiedeeling twee aan twee in paren geplaatst waren.

Dit werd in 1905 door Strasburger, Alien, Mryake en OvenTon ${ }^{4}$ ) untvoerig en voor een aantal planten beschreven. Erenals dour hosENBERG reeds eenigen tijd

1) M. L. Guignard. Le développement du pollen et la véduction chromatique dans le Najas major. Arch. d'an. mier, Bd. 2, 1899, p. $455-509$.

$\left.{ }^{2}\right)$ Victor Grégoire. Les cinèses polliniques chez les Liliacées. La Cellule, Vol. XVI, 1899, p. 235-297.

3) E. Strasburger. Ueber Reduktionsteilung, Spindelbildung, Centrosomen und Cilienbildner im Pflanzenreich. Hist. Beitr., Heft V1, Jena, G. Fischer, 1900.

4) E. Strasburger. Typische und allotypische Kernteilung.

Charles E. Allen. Das verhalten der Kernsubstanz wïhrend der Synapsis in den Pollenmutter zellen von Lilium canadense.

K. MIrake. Ueber Reduktionsteilung in den Pollenmutlerzellen einiger Monocotylen.

J. B. Overtos. Ueber Reduhtionsteilung in den Pollenmutterzellen einiger Dicotylen Jaltrb. f, wiss. Bot., Bd. XLII, 1906. 
te voren voor somatische kernen was geschied, namen zij in de kernen der moedercellen waar, dat een gedeelte van elk chromosoom in het ruststadium niet gealveoliseerd was en daardoor zichtbaar bleef. Overton gaf aan deze chromatine-lichamen den naam van prochromosomen. In de moedercellen liggen deze nu reeds van den beginne af gepaard, of wel de paring wordt eerst kort voor de synapsis duidelijk. In elk geval zijn er evenveel paren van prochromosomen, als el paren van chromosomen bij de deelingen optreden. Strasburger noemde de prochromosumen in moedercellen gamosomen. Dan volgt het stalium der snapsis, warbij de gamosomen elkander naderen en tot zygosomen samenkomen. Men stelde zich nu wel niet meer voor, dat de chromosomen in één enkelen kerndraad achter elkaar geplaatst waren, maar meende toch, dat er twee naast elkander liggende kerndraden aanwezig waren. In elk daarvan zouden weer de chromosomen van één der beide in het vegetatieve leven aanwezige stellen achter elkander gerangschikt zijn en wel zoo, dat in de beide kerndraden telkens twee homologe chromosomen tegenover elkander kwamen te liggen. In verband hiermede meende men nu ook, dat uit het synapsis-kluwen een doorloopende dubbele draad te voorschijn kwam, van welke de overlangsche helften uit de achter elkaar geplaatste en in de lengte gestrekte gamosomen zouden bestaan. Deze in de lengte gestrekte gamosomen noemde StrRasburger gamomiten ${ }^{1}$ ). Vervolgens werd waargenomen, dat de gamomiten met elkander versmelten tot zygomiten, waarbij de dubbele natuur van den kerndraad verdwijnt. Men stelt zich voor, dat hierbij eene omwisseling van de stoffelijke

1) $\mu i$ tos $=$ draad. 
dragers der erfelijkheid plaats grijpt. Bij Lilium schijnen de gamomiten ook wel reeds met elkander versmolten uit het synapsis-kluwen te roorschijn te komen. Later splitsen de zygomiten zich weer in gamomiten en treedt dus de dubbele draad weer op. Daarna zou deze zich in een generatief aantal paren segmentecren. Deze worden korter en dikker en bij de cerste deeling gaan de beide chromosomen, die samen een paar vormden, naar de polen der spoel uiteen, waarbij zij eene overlangsehe splitsing begimnen te vertoonen. Eene dergelijke paring en versmelting van chromosomen in de prophase, gevolgd door eene segmentatie in sen grencratief antal leden na de synapsis, was reeds te voren door ALLEN 1) beschreven. Opmerking verdient nog eene waarneming, die door Mryake bij Galtonia en Tradescantia werd gedaan. Bij deze planten zag hij na de synapsis een gereduceerd aantal paren optreden, naar hij meende, door segmentatie van een dubbel spireem. Nadat de paren waren gevormd, konden hun beile chromosomen echter uiteen wijken en met de chromosomen van andere paren reeksen van meerdere achter elkander liggende chromosomen rormen. I)it wekt den schijn, alsof ecu kerndraar met achter cllkander gुeplatste, in plats van gepaarde chromosomen, op vroegere stadiën aanwezig geweest was.

Een belangrijk vraagpunt is ook, of inderdaad nu een dubbele kerndraad aanwezig is, en of elk dezer draden uit het generatieve aantal achter elkander geplaatste chromosomen bestaat. OverToN laat zich

$\left.{ }^{1}\right)$ Charles E. Allen. Chromosom reduction in Lilium canadense Bot. Gaz., Vol. XXXVII, 1904, p. 464-470 on Nuclear division in the pollenmother-cells of Lilium canadense. Annals of Bot, Vot. XIX, 1905, p. $189-258$. 
reeds in dien zin uit, dat het niet noodzakelijk is, dat de chromosomen in twee doorloopende draden gerangschikt zijn. Rosenberg ${ }^{1}$ ) doet dit eveneens in cene studie over de reductie-deeling bij Listera, Tanacetum, Drosera en Arum. Maar in het bijzonder is GRÉGOIRE 2) tegen het aannemen van een, ,spirème continu". Hij en BERGHS ${ }^{3}$ ) huldigen ook eene eenigszins andere opratting van de synaptische rerschijnselen als STRASBURGER, ofschoon zij in de hoofdzaken met hem overeenstemmen. Uit het netwerk van de rustende kern zien zij lange dunne draden optreden en geen gamosomen. Die dume draden paren zich al voor het synapsis-stadium en doen dan het dikke spireem on tstaun. Later heeft GrÉGOIRE 1) nog eens bij een aantal planten nagegaan, hoe de paren der diakinese ontstaan. Hij gebruikte roor dit onderzoek Galtonia, Allium fistulosum, Lilium speciosum en L. Martagon en Osmunda. Op het ruststadium volot het leptonema-stadium, waarin paren van fijne draden optreden. In het nu volgende zygonema-stadium naderen die draden tot elkaar, maar blijven gescheiden. Er heeft nl. volgens GRÉGOIRE geen versmelting tusschen de chromosomen van een paar plaats. Door het samenkomen van de dunne draden twee aan twee worden schijnbaar onverdeelde dikke draften gevolmol; dit heet daarom het pachynema-stadium. Dan verwijderen de beide samenstellende draden van elk paar zich weer van

') O. Rosenberg. Zur Kenntnis dev Reduktionsteilung in Pfanzen. Bot. Notiser, Lund, 1905, p. 1-24.

$\left.{ }^{2}\right)$ Victor Grégoire. La réduction numérique des chromosomes et les cinèses de maturation. La Cellule, Vol. XXI, 1904, p. 297-314.

3) J. BerGHS. La formation des chromosomes hétérotypiques dans la sporogénèse végétale. La Cellule, Vol. XXI, 1904 en Vol. XXII, 1905.

4) VICTOR GrégoIre. La formation des gemini hétérotypiques dans les végéturux. La Cellule, Tol. XXIV, 1907, p. 369-420. 
elkander en winden zich in het strepsinema-stadium dikwijls om elkanter. "Il sont plus ou moins notablement entrelacés l'un autour de l'autre. Ces entrelacements sont absolument caractéristiques de la prophase hétérotypique" 1). Deze om elkaar gewonden paren „n'ont plus à subir qu'un raccourcissement et un épaississement progressifs pour devenir les gemini définitif's de la diacinèse" 2).

Hieruit blijkt dus, dat Grégorre en StTrasburger het geheel met elkander eens zijn, dat de paren der diakinese reeds zeer vroeg in de prophase als zoodanig optrenlen. Slechts ten opzichte van ombergeschilite punten verschillen zij van meening. STRAsBurger ziet daarbij dikke gamosomen, GrÉgorre echter fijne draden zich paren; de eerste neemt tevens tijdens of na de synapsis eene versmelting waar, die door GRÉGOIRE wordt ontkend.

Wat het hoofilpunt betreft hebben verschillende onderzockers zich aan de zijde van STTRAsburger en GrÉgorre geschaard. Sommigen nemen daarbij echter in de prophase eene paring ran dikke gamosomen, zooals StTRAsBURGER, anderen eene paring van parallele draden, zooals GréGolre,

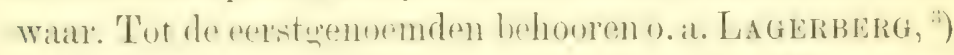
die bij Adoxa, en Rosenberg ${ }^{*}$ ) die bij Hieracium dikke gamosomen waamamen. Ook de opratting van het verloop der praesynaptische stadiën bij Nymphacaceae,

1) 1. c., p. 372 .

2) l. c. p p. 373 .

3) T. LAgerberg. Ueber die praesynaptische und synaptische Entwicklung der Kerne in den Embryosackmutterzellen von Adoxa moschatellina. Bot. stud, tillägn. F. R. Kjellman, Uppsala, 1906.

4) O. Rosesiera. Cytological studies on the apogamy in Hieracium. Bot. 'Tidsskrift, Bd. 28, 1907 , p. 143-170.

O. ROSENBERG. Zur Kenntnis der praesynaptischen Entwicklungsphisen der Redutionsteilung. Srensk Bot. Tidskt., Bd. 1, 1908. 
zooals die door Lubimenko en Maige ${ }^{1}$ ) is gegeven, stemt hiermede overeen. Gamosomen heeft ook OvERTon ${ }^{2}$ ) onlangs weer gezien bij Thalictrum purpurascens, Calycanthus floridus en Richardia africana. RosenbeRG ${ }^{3}$ ) beschrijft, dat bij Crepis virens slechts 6 chromosomen in het vegetatieve leven voorkomen en dat deze bij de deelingen drie paren van verschillende lengte vormen. In de rustende vegetatieve kernen, zoowel als in de kernen der pollen-moedercellen, zijn 6 meer of minder duidelijk in paren gerangschikte prochromosomen to zien. In de synapsis liggen fijne draden parsgewijze en versmelten ten slotte met elkander. Ook hicr zijn dus onrspronkelijk gamosomen, dic zich tot dumme draden strekken. LUNDEGARDH ${ }^{*}$ ) neemt bij Calendula officinalis, Achillea Millefolium, Anthemis tinctoria en Matricaria Chamomilla in de rustende kernen der pollen-moerlercellen meest duidelijk gepaarde prochromosomen waar. Deze strekken zich tot gamomiten en smelten vervolgens ineen. Zoo zijn dus tal van voorbeelden te noemen, waarin het optreden van gamosomen, m. a. w. van grootere chromatine-massa's, die in aantal met de chromosomen overeenstemmen, is beschreven.

Aan den anderen kant is het copuleeren van fijne draden in de prophase, zonder dat eerst gamosomen

1) W. Lubimenko et A. MAige. Recherches cytologiques sur le développement des cellules-mères du pollen chez les Nymphéacées. Rev. gén. de Bot., T. XIX, 1907.

$\left.{ }^{2}\right)$ J. B. Overton. On the Organization of the Nuclei in the Pollen Mother-cells of Certain Plants, etc. Ann. of Bot., Vol, XXIII. Jan. 1909.

3) O. Rosenberg. Zur Kenntnis von den Tetradenteilungen der Compositen. Srensk Bot. Tidskr., Bd. 3, 1909, H. 1.

4) Henrik Lundegådi. Ueber Reduktionsteilung in den Pollenmutterzellen einiger dicotylen Pflanzen. Srensk Bot. Tidskr., Bd. 3, 1909, H. 1. 
optreden, door C.IRDiFF ${ }^{1}$ ) beschreven en eveneens door LUNDEG IRDH, en wel bij Trollius europaeus, alsmede door Yamanoucur ${ }^{2}$ ) bij de spore-vorming van Nephrodium molle.

Alle tot dusver genoemde onderzoekers zijn het er dus over eens, dat in de rustende kernen der moedercellen chromosomen gepaard naast elkander liggen en dat zij aldus gepaard blijven tot an het stadium der diakinese.

Andere, eveneens talrijke, schrijvers hebben zich echter niet met de opvattingen van S'TRASBURGER en GrÉGorkE kummen vereenigen. Ook zij zien rlikwijls de scheirling, die vroeger beschouwd werd als eene eerste lengtesplitsing. Maar zij besluiten hieruit niet tot eene paarsgewijze ligging der chromosomen in de prophase. Veclecr houden zij deze scheiding roor eene werkelijke splitsing, voor die nl., die de chromosomen bij eene normale deeling zouden ondergaan. Deze aanduiding van eene lengtesplitsing zou dan weer verdwijnen, narmate het spircem korter en dikker wordt. Volgens humne opvatting bestatt er wèl een doorloopende kerndraad, waarin de chromosomen achter elkander zijn gerangschikt. Uit het synapsis-kluwen zouden lissen te voorschijn komen en humne beenen zouden ieder een chromosoom vertegenwoordigen. De paren der diakinese zouden zóó totstand komen, dat de heenen dezer lissen zich tegen elkander zouden leggen, terwijl eene dwarsche doorsnoering der lissen aan het distale cinde plaats vond. Als cen der voor-

3) I. D. CARDIFF. A study of synapsis and reduction. Bull. 'Tor. Bot. Club, Bd. 33, 1906, p. 271-306.

2) Sir. Yamaxodchi. Sporogenesis in Nephrodium. Bot. Gaz., Bd. 45, Jau. 1908, p. 1-30. 
naamste vertegen woordigers dezer richting moet FARMER 1) genoemd worden. Opmerkenswaardig is, dat hij en zijne medewerkers Moore en SHove gedeeltelijk dezelfde planten onderzochten als STRAsburger en GrÉGoIre; zoo bijø. Lilium, Osmunda en Tradescantia. Hetzelfde geldt voor Mottier ${ }^{2}$ ), die bijv. Podophyllum, Lilium, en Tradescantia bestudeerde. Schaffner ${ }^{3}$ ), die ook eene Liliumsoort, nl. L. tigrinum nevens Agave virginica onderzocht, kwam tot een gelijk resultaat. Verder noem ik als aanhangers van FARMER nog LEWIS ${ }^{4}$ ), die geen paring van chromosomen in praesynaptische stadiën waarnam en voor Pinus en Thuja beschrijft, dat hier dwarsche doorsnoeringen in een postsynaptisch spireem plaats hebben. Merkwaardig is, dat Yamaxouchi, die bij Nephrodium wel paring gevonden had, daarvan bij Fucus ${ }^{5}$ ) niets kon ontdekken. Hier neemt hij een enkelvoudig spireem waar, dat uit de afwisselend achter elkander gerangschikte vaderlijke en moederlijke chro-

1) J. B. FARMER and J. E. S. MoORE. New Investigations into the Reduction Phenomena of Animals and Plants. Proc. of the Royal Soc., Vol. 72, 1903.

J. B. FARMER and J. E. S. MoOrE. On the maiotic phase (reduction division) in animals and plants. Quart. Journ. micr. Sc., Bd. 48, 1905.

J. B. FARMER and D. SHove. On the structure and development of the somatic and heterotypic chromosomes of Tradescantia virginica. Quart. Journ. micr. Sc., Bd. 48, 1905.

$\left.{ }^{2}\right)$ D. M. MOTTIER. The development of the heterotypic chromosomes in pollen mother cells. Bot. Gaz., Bd. 40, 1905 en Ann. of Bot., Bd. XXI, 1907.

3) J. H. SCHAFFNER. Chromosome reduction in the microsporocytes of Lilium tigrinum. Bot. Gaz., Bd. 41, 1906, en Anu. of Bot., Bd. XX, 1906.

J. H. SCHAFFNER. The reduction division in the microsporocytes of Agave virginica. Bot. Gaz., Bd. 47, 1909.

$\left.{ }^{4}\right)$ I. M. LEwis. The behavior of the chromosomes in Pinus and Thuja. Ann. of Bot., Bd., XXII, 1908.

i) Sh. Yamanouchr. Mitosis in Fucus. Bot. Gaz., Bd. 47, 1909. 
mosomen zou bestaan, en ziet hij lissen optreden, die ieder twee met de einden verbonden chromosomen zouden vertecenwoordigen. In dr\% verhandeling vermeldt hij rexks roorloopig, dat hij hij Osmunda wel de paring der chromosomen heeft wararenomen en hij uit dus de meening, dat er twee typen van reductie-deeling zouden kunnen bestaan. Verder staan ook Gregory ${ }^{1}$ ) en Williams ${ }^{2}$ ) aan de zijde van FARMER.

Ten slotte wil ik or nog op wijzen, dat de drie onderzockers, die de reductie-deeling bij soorten van Ocnuthera ${ }^{3}$ ) hebben bestudeerd, nl. GATES bij O. rubrinervis, Geents bij O. Lamarckiana en DAvis bij 0 . grandiflora, van meening zijn, dat deze hier volgens het schema van FARMer verloopt. Gates neemt in de prophase nog cene dubbele structuur waar, maar meent die in den zin van Farmer te moeten uitleggen. GeErts heeft ook daarvan niets wargenomen. Beiden zien zij na de synapsis het vegetatieve aantal chromosomen optreden, dikwerf in lange recken achter elkiar gerangschikt. DAvis ziet in dit stadium een zevental ringen optreden, vam welke een deel uit lissen zoulen ontstaan zijn, die uit het synapsis-kluwen te voorschijn kwamen. GATEs maakte uit zijne onderzoekingen deze gevolgtrekking $\left.{ }^{4}\right)$. "Lvidence from this and other work shows that there are two general methods of chromosome reduction in plants, one involving a side-by-side

1) R. P. GREGORY. Spore-formation in leptosporangiate ferns. Ann. of Bot., Bd. XVIII, 1904.

2) J. L. Williams. Studies in the Dictyotacene. I. Ann. of Bot., Bd. 18,1904 .

3) 1. c.

4) R. R. GATES. The behavior of the chromosomes in Oenothera lata $\times$ O. gigas. Bot. Gaz., Bd. 48, 1909, p. 195. 
pairing of chromatin threarls (parasrnapsis) to form a double spirem; the other involving an end-to-end arrangement (telosynapsis) of the maternal and paternal chromosomes to form a single spirem, which may afterward split longitudinally". IIet komt mij voor, dat, waar het een zoo fundamenteel en grewichtig verschijnsel geldt, dit alsnog niet aannemelijk is. Op dit punt zal ik echter terugkomen, nadat ik in de beide volgende paragrafen beschreven zal hebben, hoe bij Spinacia de reductie-deeling verloopt.

\section{§ 2. Het ontstaan der diakinese-paren bij Spinacia.}

Zooals ik reeds in de inleiding heb gezegd, heb ik de reductie-deeling voornamelijk bij de ontwikkeling van het stuifmeel bestudeerd, terwijl ik de deelingen van embryozak-moedercellen slechts in zooverre onderzocht heb, als noodig was, om mij er van te overtuigen, dat zich hierbij dezelfde rerschijuselen voordoen, als in de pollen-moedercellen. Om deze reden zal ik beginnen met eene beschrijving van mijne waarnemingen aan deze laatsten. Vooraf moge eene opmerking ingelast worden over de vraag, hoe men den ouderdom der preaparaten beoordeelen kan.

Op doorsneden door jeugdige antheren, waarin de moedercellen der stuifmeelkorrels zich in het ruststadium bevinden, kan men zien, dat zoowel deze cellen, als de omgevende wand- of tapeten-cellen nauwkeurig aaneensluiten. Deze wandcellen kleuren zich in dit stadium iets donkerder dan de moedercellen. Naarmate deze 
laatsten verder in hare ontwikkeling vorderen, wordt dit versehil in klour allengs duidelijker. Tegelijkertijd beginnen de wandcellen en later ook de moedercellen elkander los te laten. Door op deze beide kenmerken te letten, kan men bij het onderzoeken van cen praeparaat terstond beoordeelen in welk stadium der ontwikkeling de moedercellen in ecne bepaalde anthere zich bevinden. 'Tot aan de synapsis plegen de moedercellen en meestentijds ook de wandcellen aaneengesloten te blijven en kleuren de laatsten zich slechts weinig donkerder dan de eersten. Hierdoor kan men dus steeds met groote zekerheid beslissen, of men een prae- dan wel een postsynaptisch stadium bestudeert.

De kernen der moedercellen vertoonen in het ruststadium bijna geen kleurbare deeltjes. Slechts de nucleolus is duidelijk zichtbaar. Zoodra echter de prophase der deeling is begonnen, treden kleine korrels van chromatine op. Van deze liggen telkens verscheidene achter elkander op een linine-draad. Deze draden liggen op geringe afstanden paarsgewijze en dragen de korrels van chromatine telkens twee an twee tegenover elkander. Nu naderen deze draden tot elkaar en de chromatine-korrels smelten inéén (Pl. I, fig. 7). Daardoor ontstaan banden, die dus uit twee fijne parallele draden bestaan, waartusschen hier en daar ophoopingen van chromatine liggen. Tusschen een zoorlanigen band en cen smal chromosoom, dat zich in de prophase van eene typische kerndeeling bevindt, valt eene sterke overeen komst op te merken (vergelijk tekstfiguur C, blz. 83). Uit het verdere verloop der deeling blijkt dan ook, datzulk een fijne linine-draad met achter elkander geplaatste chromatinekorrels een chromosoom vertegenwoordigt. De band, die op deze wijze door het tot elkaar naderen van twee 
draden en de versmelting hunner chromatine-korrels wordt gevormd, bestaat dus uit twee zijdelings met elkander verbonden chromosomen. Daar in het vegetatieve leven bij Spinacia 12 chromosomen worden aangetroffen, zou men dus ook verwachten 6 dergelijke banden te zien. Op deze allervroegste stadiën is dit echter nog niet mogelijk. Wel zag ik, dat nu tegen den nucleolus eenige, en wel zeer dikwijls juist 6 , zich donkerkleurende korrels liggen en dat van deze uit telkens een paar linine-draden zijn oorsprong schijnt te nemen. Over de mogelijke beteekenis hiervan zal ik in de laatste § van dit hoofdstuk spreken. Zoodra de prophase iets verder is gevorderd, kan men in vele cellen echter 6 banden, d. w. z. 6 paren ran chromosomen, onderscheiden. Fig. 8 en Fig. 9 op Pl. I geven twee kernen weer, die zich in dit stadium berinden. Dat de banden, die in deze beide figuren worden gezien, dubbel zijn, blijkt ten eerste uit de rele splijtingen, die er in voorkomen. Men ziet deze in beide figuren bijr. in het chromosomenpaar, dat met 1 is gemerkt, verder in het paar 4 in Fig. 9, enz. In de tweede plaats blijkt de dubbelnatuur der banden uit de dubbele uiteinden, die dikwijls worden gezien, zoo bijv. bij band 3 in Fig. 8 en bij band 1 in Fig. 9. Uit deze figuren volgt, dat er niet van een doorloopenden dubbelen kerndraad en nog minder van een enkelvoudigen kerndraad sprake kan zijn. Elk der 12 chromosomen treedt in de prophase op als een fijn draadje, waarop chromatine-korrels geplaatst zijn en dat twee rrije uiteinden heeft. Twee parallele draden vormen samen een band, die dus ook twee rrije uiteinden heeft. De 6 banden moeten dus te zamen 12 vrije uiteinden hebben. Maar het is niet altijd mogelijk, om in één kern deze allen te zien. Dit 
is bijv. het geral in het stadium, dat in Fig. 10, Pl. I is afgebeeld. Wel blijkt hier door de vele splijtingen, waarvan er een paar door een sterretje zijn aangeduid, dat de banrlen dubbel zijn. Verder moet nog opgemerkt worden, dat men natuurlijk niet in alle moedercellen zoo fraaie stadiën kan waarnemen, als in de figuren S, 9 en 10 zijn afgebeeld. ILet komt mij voor, dat de praesynaptische stadiën voor verschillende invloeden buitengewoon gevoelig zijn. Somtijds ziet men in eenzelfde anthere talrijke moedercellen, wier kernen er uitzien als in de genoemde figuren, en andere, in wier kernen men slechts een verward complex van dunne draden waarneemt. Moet dit daaraan worden toegeschreven, dat deze kernen bijzonder arm zijn aan chromatine? Waarschijnlijker schijnt het mij toe, dat het zeer mocilijk is, om de praesynaptische stadiën zóó te fixeeren, dat de structur in alle cellen geheel onveranderd blijft. Overigens vormen ongetwijfeld de beelden, zooals it ze heb geteekend, de meerderheid en hier is geen twijfel aan de dubbele natuur der banden mogelijk. Nisschien staat hiermede in verband, dat ook bij die stadiën, die onmiddellijk aan de vorming van het synapsis-kluwen voorafgaan, niet altijd cenzelfde structuur wordt waargenomen. Fig. 11 op Pl .I toont een beeld, dat zich aan de figuren 8 en 9 aansluit. De banden zijn rijker aan chromatine en daarbij dikker en korter geworden. Overigens zijn er nog 6 te zien en verraden zij humne dubbele natuur don splijtingen en door gevorkte uiteinden, zooals die bijv. aan het rechtsehe cinde der paren 1 en 2 roorkomen. De synaptische contractio is hier begonnen. Hierop volgen stadiën, als die, welke in Figg. 14 en 15 afgebeeld zijn en waarin het synapsis-kluwen bijna gereed is. Ook hier blijkt 
de dubbele natuur der draden nog door splijtingen. Deze ziet men bijv. in Fig. 14 bij *.

Het is mij opgevallen, dat er een verband schijnt te bestaan tusschen den nucleolus en het complex der chromosomen. Reeds naar aanleiding van hetgeen in Fig. 7 op Pl. I is afgebeeld heb ik hierop gewezen. Bij het ontstaan van het synapsis-kluwen trof het mij, dat dit steeds tusschen den nucleolus en den kernwand schijnt aangelegd te worden. In Fig. 13 ziet men, hoe de nucleolus door het ontstaan ran het synapsis-kluwen van den kernwand afgedrongen wordt. In verreweg de meeste gevallen ligt hij later aan de van den wand afgekeerde zijde van dit kluwen, terwijl dit laatste tegen den kernwand ligt. Daarbij blijven nucleolus en kluwen met elkander verbonden. Fig. 13 toont een synapsiskluwen, waarin men de 6 paren der chromosomen niet kan onderscheiden. Hetzelfde is het greval in Fig. 12. Deze figuur heb ik echter geteekend, omdat twee der paren er bijzonder duidelijk in uitkomen. Zij zijn met a en $b$ gemerkt en vertoonen zeer fraaie splijtingen en dubbele uiteinden.

Thans is het stadium der synapsis bereikt. Fig. 1, Pl. II geeft eene afbeelding van eene dwarsche doorsnede eener anthere, welker moedercellen zich in dit stadium bevinden. De wandcellen zijn begonnen elkander los te laten en vertoonen meestal twee kernen.

Dat tapeten-cellen meerkernig kunnen worden, is een verschijnsel, dat in den laatsten tijd raak de aandacht heeft getrokken. Het wordt door eene deeling van de oorspronkelijk aanwezige kern te weeg gebracht, waarop geene celdeeling volgt. Ook kunnen wel meer dan twee kermen in eene cel optreden, doch dit heb ik bij 
Spinacia niet wargenomen. Van nu af aan kleuren deze wandcellen zich zeer donker.

Zooals wij gezien hebben, ontstond het synapsis-kluwen daardoor, dat 6 banden, ieder bestaande nit 2 zijdelings met elkander versmolten chromosomen, zich te zamen balilen. Hieruit laten zich nu de volgende verschijnselen gemakkelijk verklaren. In Fig. 2, Pl. II ziet men, dat een dikke draad uit het kluwen, dat duidelijk met den nucleolus samenhangt, te voorschijn is gekomen en dat deze draarl eene aunduiding van eene lengtesplitsing vertoont. Wanneer men nu bedenkt, dat het kluwen uit 6 door elkaar gewonden paren van draden bestaat, dan is het duidelijk, dat, wanneer een kluwen losser gaat worden, een draden-paar het eerst met een zijner vrije uiteinden te voorschijn kan komen of wel met een meer in zijn midden gelegen gedeelte. In dit laatste geval zal men dus eene lis zich uit het kluwen zien uitschuiven. Zulk een geval is in Fig. 3, Pl. II weergegeven. Hier is een gestrekte, duidelijke dubbele drata buiten het kluwen gekomen, terwijl men verder twee kleine lissen opmerkt. De ontwikkeling van het synapsiskluwen schrijdt nu voort. In Fig. 4, Pl. II zijn er drie kleine lissen en twee gestrekte draden buiten gekomen, waarvan de beide laatsten weer duidelijk dubbel zijn. De knik bij a meen ik hicrdoor te moeten verklaren, dat dit paar als lis is ontstaan en dat eerst later zijn eene uiteinde uit het kluwen vrij werd. In Fig. 5, Pl. II ziet men buiten het kluwen vier gestrekte draden en eene lis. In alle paren ziet men aanduidingen van overlangsche splitsingen, vooral in lat, hetwelk naar boven is gericht. De beide naar links gerichte vertoonen eene buiging, die waarschijnlijk aanduidt, dat zij oorspronkelijk lissen waren. 
Nog iets verder is het stadium gevorderd, dat Fig. 6, Pl. II vertoont. Hier ziet men drie lissen en drie gestrekte draden met hier en daar splijtingen. De beide naar links gerichte paren zijn klaarblijkelijk weer geopende lissen. Ik leg er den nadruk op, dat alle afgebeelde kernen van moedercellen niet door het mes waren aangesneden. Slechts die kernen heb ik voor het vervaardigen ran teekeningen uitgekozen, waarboven en waarbeneden bij veranderde instelling van het microscoop protoplasma aanwezig bleek te zijn. Dat de lissen geopend zijn, kan dus niet door het wegsnijden van een gedeelte er van veroorzaakt zijn.

Een verder stadium toont Fig. 7, Pl. II. Het synapsis-kluwen wordt steeds kleiner en er komen drie lissen met vrije uiteinden, nl. die met 1, 2 en 3 zijn aangeduid, en drie gesloten lissen (4,5 en 6) uit te voorschijn. De dubbele draden worden nu gelijkmatig korter en dikker, terwijl achtereenvolgens de verschillende lissen zich openen. In de figuren 8 en $9, \mathrm{Pl}$. II, is er nog maar één gesloten, in Fig. 10 zijn zij alle geopend. Dat de dikke draden hier werkelijk paren zijn, blijkt uit de hier en daar zichtbare splijtingen, en tevens daaruit, dat de beide uiteinden, die het meest naar links liggen, duidelijk dubbel zijn. Merkwaardig is, dat het door * aangeduide paar thans nog een knik vertoont, die or op wijst, dat het vroeger een lis-rorm moet gehad hebben. Ook ziet men, dat van alle paren het eene uiteinde in het nu veel kleiner geworden kluwen is blijven ligoren.

In Fig. 11, Pl. II is een nog later stadium afgebeeld, waarin de paren nog korter zijn geworden. Verscheidene paren zijn duidelijk gespleten en ook dubbele uiteinden kan men bij a en b opmerken. In het met * aangeduide 
paar ziet men weer een knik. Een dergelijk stadium toont ook Fig. 12, Pl. II. De paren a en b hebben hier elk cen fraai gevorkt uiteinde, de overige paren vertoonen in hun midden eene overlangsche splitsing. Dit is ook bij de beide onderste het geval, die eene T-rormige gedlaante hebben, waarschijnlijk ten gevolge van cen vroegeren lis-vorm. De paren blijven, zelfs tot onmiddellijk vóór de diakinese, met hun eene uiteinde in het kluwen samenhangen. Dit blijkt duidelijk uit Fig. 13, Pl. II. Hier hebben zij hunne definitieve gedaante bereikt, op het bovenste na, dat nog geknikt is, maar duidelijk volgens de lengte is gesplitst. De overige paren bestaan uit twee naast elkander liggende chromosomen, die nu uiteen kumnen wijken, zoodat zij eene $\mathrm{O}$ of eene $\mathrm{V}$ gain vormen. Twee dergelijke paren zijn in deze kern juist vrij gekomen.

Thans rolgt het stadium der diakinese, dat door de figuren 14-18, Pl. II wordt voorgestell. Kenmerkend hiervoor is, dat de paren zeer dikwijls een ring- of een V-vorm aannemen. Zoo merkt men in Fig. 14 vijf V-vormige paren en één ringrormig parar (a) op; $V^{\prime}$-rormige paren zijn ook in de overige figuren afgebeeld; een ring ziet men links van den nucleolus in Fig. 16. Ook is het mogelijk, dat de beide leden van een paar elkander geheel los laten. Dit is bijv. bij * in Fig. 16 geschied.

Vatten wij nu de gegeren beschrijving ran het ontstaan van de paren dex diakinese bij de pollen-vorming in korte woorden te zamen. De 12 in het vegetatieve leven aanwezige chromosomen legren zich in een vroeg praesynaptisch starlium twee alu twee naast elkander, en wel in den vorm van dunne draden, waarop van afstand tot afstand chromatine-korrels worden war- 
genomen. Deze laatsten rersmelten met elkander en zoo ontstaan 6 banden, die ieder een paar chromosomen vertegenwoordigen en dus twee vrije uiteinden hebben. In het synapsis-kluwen zijn deze banden door elkander gewonden. Wanneer dit zich gaat ontwikkelen, kan van een paar het eerst één der vrije uiteinden te voorschijn komen, maar in den regel treedt een meer naar het midden gelegen gedeelte als lis naar buiten. Elke zoodanige lis bestaat uit twee naast elkander liggende en nict uit twee achter elkaar geplaatste chromosomen, en is dus eigenlijk eene dubbele lis. In den regel komt ten slotte het eene uiteinde van elk lisvormig paar uit het kluwen rrij, waarbij eene gelijkmatige verkorting en verdikking van de beide leden van het paar plaats grijpt. Hierbij kan de vroegere lis-vorm als knik ook dan kenbaar blijven, als het paar reeds sterk verkort is. Met het andere uiteinde blijven de 6 paren langen tijd in het kluwen te zamen hangen. Dit duurt in den regel tot onmiddellijk vóór de diakinese. Dan wordt het verband verbroken en plaatsen de paren zich tegen de kernmembraan, waarbij zij O-vormig of V-vormig kumnen worden of zelfs geheel in de beide samenstellende chromosumen kunnen uiteen vallen.

Thans ga ik over tot de beschrijving van mijne waarnemingen aan cmbryozak-moedercellen. Zooals men zien zal, bevestigen zij het bovenstaande.

De jonge zaadknop is door een duidelijk dermatogeen overdekt. Eén subepirlermaal gelegen peribleem-cel wordt tot archespoor-cel. Van een meercellig archespoor heb ik nonit eene aanduiding gevonden. Deze archespoor-cel deelt zich in eene periphere wandcel en in de meer naar binmen gelegen embryozak-morlercel. In het alge- 
meen kan zich de wandeel nu op versehillende wijzen gedragen; zij kan door pericline wanden tot een enkele reeks van cellen worden, maar wanneer de embryozakmoedereel zeer breed worlt, kan bij de eerste deeling ook eene anticline wand optreden. Dit laatste heb ik bij Spinacia watrgenomen en in Fig. 1, Pl. I afgebeeld. Terwijl nu de embryozak-moedercel de verschillende stadiön der reductie-deeling doorloopt, deelt zich de distaal gelegen laag van cellen door pericline wanden, zoodat de embryozak-moedercel alleng's dieper in het nucellus-weefsel komt te liggen. Het aantal der lagen, dat aldus boven de embryozak-moedercel optreedt, schijnt bij de verschillende soorten van Spinacia te kumnen variëeren. Bij eene soort nam ik, tot het diakinesestadium bereikt was, eene geleidelijke vermeerdering van het aantal lagen tot 5 waar; na de eerste deeling was dit aantal tot 7 gestegen. Daarentegen waren bij eeue andere soort tijdens het synapsis-stadium reeds 4 à 6 lagen aanwezig en in het stadium, waarin de lissen uit het kluwen te voorschijn kwamen, telde ik er reeds 8 .

In de embryozak-moedereel zict men in de kern, wanneer deze de prophase van de deeling intreedt, gepaarde chromatine-korrels en fijne parallele draden, die hier en daar door chromatine zijn verbonden, juist zooals in de kernen der pollen-moedereellen. Dit is in Fig. 1, Pl. I weergegeven en wel iets overdreven, daar de lithograaf de lijnen iets te forsch heeft overgenomen. De ontwikkeling van het synapsis-kluwen heeft op dezelfre wijze plaats, als in de pollen-moedercellen. Dit blijkt uit de figuren 2 en 3 op Pl. I, waarin men dezelfde lissen en gestrekte draden, onk mot aanduidingen van overlangsche splitsingen, ziet. E'me nauwkeurige beschouwing verdient Fig. 4, Pl. I. Men moet zich 
voorstellen, dat de 6 paren alle met hun eene uiteinde uit het synapsis-kluwen zijn vrijgekomen. Het andere uiteinde ligt nog ongeveer in het midden van de kern, zoodat daar ter plaatse nog een rest van het kluwen aanwezig is. Het paar, dat met e e is gemerkt, is naar boven omgebogen, hetgeen waarschijnlijk weer aan een vroegeren lis-vorm moet toegeschreven worden, en bestaat klaarblijkelijk uit twee zijdelings naast elkander liggende chromosomen. Dit laatste is eveneens het geval met de paren $a \mathrm{a}, \mathrm{b} b$ en $\mathrm{c} c$. De periphere einden der paren d d en ++ wijken uiteen. Merkwaardig is, dat de beide vertakkingen, d. w. z. de beide samenstellende chromosomen, nog eens gesplitst zijn. Ik schrijf dit toe aan het optreden van de overlangsche splitsing, die gewoonlijk eerst bij het einde van de eerste deeling duidelijk wordt. Dezelfde lengte-splitsing merkt men nog op latere stadiën op. Fig. 5, Pl. I toont eene kern van eene embryozak-moedercel kort voor de diakinese. In dit geval blijren de paren niet, zooals ik dat voor de pollen-vorming beschreef, tot dit tijdstip in het midden samenhangen. Men ziet, hoe zij uiteenglijden en daarbij nog bezig zijn korter en dikker te worden. In het paar nu, dat met a is aangeduid, is in beide chromosomen de bedoelde lengte-splitsing nog aanwezig. Ook in de diakinese, die door Fig. 6, Pl. I wordt voorgesteld, is zij waar te nemen. Men kan hier 4 gedrongen paren tellen en één paar, warran de beide chromosomen, die door * zijn aangewezen, elkander geheel hebben losgelaten. Bij a merkt men echter eene viertallige groep, eene tetrade, op. Toch zijn dit slechts 2 chromosomen. Maar deze zijn ieder in het bijzonder reeds in de lengte gesplitst. Gewoonlijk treedt deze splitsing cerst op, wannecr de chromosomen zich naar 
de polen begeven en tetraden, zooals hier beschreren, behooren, ten minste in het plantenrijk, tot de uitzonderingen.

Over het algemeen bevestigt dus het onderzoek der embryozak-moedercellen, hetgeen roor de pollen-vorming beschreven is.

\$3. De hetrotype en homointype deelingen bij sprinacia.

Wanneer eenmaal de paren der diakinese gevormd zijn, verloopt de reductie-deeling bij Spinacia verder op dezelfde wijze, als bij andere planten thans algemeen wordt aangenomen. Daarom zal ik haar hier slechts voor de ontwikkeling van het stuifmeel beschrijven.

In den regel liggen de paren van chromosomen in de diakinese in den vorm van eene $\mathrm{O}$ of van eene $\mathrm{V}$ tegen den kernwand. Wanneer nu de deeling zal plaats hebben, verdwijnt de nuclęolus en vermindert het volumen der kern. De lichtgekleurde plekken tusschen de chromosomen worden al kleiner en kleiner en ten slotte zijn de paren geheel roor protoplasma omgeren. Men zegt dan, dat de kernmembraan verdwenen is. Merkwaardig is nu, dat de paren toch hunne $\mathrm{O}$-vormige of V-rormige gerlaante behourlen hebben, zooals in Fig. 1 op Pl. III te zien is. Dit herinnert aan hetgeen BELAJEFF ${ }^{1}$ ) vroeger omtrent het tot stand liomen der reductie heeft geschreven. Ilij meende, dat de chrommsomen zich paarsgewijze in den vorm van eene $\mathrm{V}$ of eene $\mathrm{X}$ in het aequatorvlak van de spoel zouden rangschikken en dat bij de heterotype deeling niet, zonals thans

1) BeraJEFF. Ueber die Reduktionstheilung des Pflunzenkerns. Ber. d. D. Bot. Ges., 1898 . 
algemeen wordt aangenomen, het eene chromosoom ran een paar naar de eene pool, en het tweede naar de andere zou gaan, $\mathrm{m}$. a. w. dat niet de beide beenen van eene $V$ of $X$ uiteen gaan, maar dat de $V$ en de $X$ zich overlangs zouden splijten. Daardoor zouden zich $\mathrm{V}$-vormige of $\mathrm{X}$-vormige paren naar beide polen begeven en zouden deze eerst bij de homoiotype deeling in hunne beide leden worden gescheiden.

Het bleek mij echter, dat in de kernplaat van de eerste deeling bij Spinacia de $\mathrm{O}$-rormige of $\mathrm{Y}$-rormige paren niet meer te zien zijn (Fig. 2, Pl. III). Want de beide chromosomen van elk paar liggen nu tegen elkander en wel zoo, dat het eene naar de eene pool en het andere naar de tegenorergestelde gericht is. In den regel grijpen de spoeldraden de chromosomen bij dat uiteinde aan, dat het meest naar de binnenzijde van de spoel is gericht. Dit is in de Figuren 4 en 5, Pl. III weergegeren. Somtijds ziet men echter ook, dat een parr in het midden door de spoeldraden wordt aangegrepen (Fig. 3, Pl. III), waardoor dan de chromosomen bij hun uiteengaan een $\mathrm{V}$-vorm aannemen. Meestal kan men nu in elke spoel één paar vinden, dat waarschijnlijk in het midden is aangerat. Zoo schijnt in Fig. 6, Pl. III, die de chromosomen op hun weg naar de polen toont, het meest linksche, zoowel in het borenste, als in het benerdenste complex, in het midden aan de spoeldraden vast te zitten. In Fig. 7, Pl. III, zijn de chromosomen bij de polen der spoel aangekomen en zijn die, welke met a gemerkt zijn, duidelijk T'-rormig. Men zou nu kunnen meenen, dat deze V-vorm door het optreden van eene lengte-splitsing ontstaat. Inderdaad zijn in Fig. 7 alle chromosomen, die in Fig. 6 nog ongerleeld schenen, ruirlelijk in twee dicht tegen 
elkander liggende helften gesplitst. Toch komt het mịj voor, dat de beide in Fig. 7 met a gemerkte een Y-rorm hebben, omdat zij in hun midden door de spoeldraden werlen aangegrepen en niet, omdat de twee overlangsche helften iets verder uiteen wijken, dan bij de andere chromosomen.

Ik besluit hiertoe op grond van een verschijnsel, dat ik in Fig. 8, Pl. III heb afgebeeld. Men ziet, dat tusschen de chromosomen alveolen zijn opgetreden, waardoor zij van clkander worden gedrongen. Daarbij spreiden de beide overlangsche helften van elk chromosoom, die bij het einde der deeling zichtbaar zijn geworden, zich dikwijls uiteen, zoodat weer V-vormige figuren ontstaan. Bij * in Fig. 8 ziet men nu een chromosoom, dat duidelijk eene dubbele $\mathrm{V}$ vormt. Dit maakt het zeer waarschijnlijk, dat dit in het midden door de spoeldraden was aangerat. Datardoor toch kon het, terwijl het zich naar de pool begaf, den V-vorm krijgen. Tegelijk met de overice chromosomen onderging ook dit eene bij het einde der deeling eene overlangsche splitsing, en zoo ontstond dus de dubbele V. Bij het ontstaan der dochterkernen wordt dit nu duidelijker. Zooals later beschreven zal worden, is het niet onwaarschijnlijk, dat in elke spoel steeds één chromosomenpaar in het midden doer de spoeldraden wordt aangevat.

De alveolen, zooals zij in Fig. 8 worden waargenomen, worden steerls grooter, omgeven ten slotte de chromosomen, en de protoplasma-armpjes er tusschen verdwijnen. Zoo ontstaan de dochterkernen, waarvan er in Fig. 9 en Fig. 10, Pl. III twee zijn afgebceld. De chromosomen veranderen daarbij niet in belangrijke mate van esestalte. De door de lengte-splitsing veroorzatakte dubbelnatuur liomt echter messtal dujdelijk nit. Nucleolon treden nu nisot "p. 
Een punt, waarop ik nog wijzen moet, is het gedrag der doorloopende spoeldraden. Wanneer de chromosomen op weg zijn naar de polen der spoel, blijven er tusschen deze nog slechts zeer weinig verbindingsdraden over (Fig. 6). Wanneer dan de chromosomen bij de polen zijn aangekomen en de dochterkernen dus beginnen te ontstaan, wordt de ruimte tusschen deze laatsten geheel met protoplasma gevuld en het heeft den schijn, alsof de spoeldraden, die nog aanwezjg waren, worden verbroken en gedesorganiseerd. In het protoplasma merlit men nu talrijke extranucleaire nucleolen op. Later, wanneer de dochterkernen gevormd zijn, is echter een duidelijke phragmoplast of complex van verbindingsdraden tusschen de beide dochterkernen aanwezig. Het komt mij onwaarschijnlijk voor, dat deze secundaire verbindingsdrarlen door splijting van de primair aanwezige zouden zijn ontstaan, zooals thans rrij algemeen wordt aangenomen. Veeleer schijnt het, dat het cytoplasma tusschen de beide dochterkernen zich opnieuw tot fijne draden differentieert en dat daardoor de phragmoplast ontstaat. Deze voorstelling stemt overeen met hetgeen door Postma ${ }^{1}$ ) onlangs voor het ontstaan van den phragmoplast bij de vegetatieve deelingen in de worteltoppen van Allium is beschreven. In Fig. 9, Pl. III is een deel van den phragmoplast naast de kern te zien, terwijl de geheele phragmoplast, zooals die tusschen de dochterkernen aanwezig is, in Fig. 13, Pl. III afgebeeld is.

Nadat zij zich eenigen tijd in den afgebeelden rusttoestand hebben bevonden, gaan de dochterkernen zich opnieuw deelen. De kernholte wordt alleng's kleiner;

1) G. PostMA. Bijdrage tot de kennis van de vegetatieve celdeling bij de hogere planten. Diss. Groningen, 1909. 
protoplasma-verbindingen treden tusschen de chromosomen op; kleine alveolen zijn er nog tusschen zichtbaar (Fig. 11 en Fig. 12, Pl. III.) Naar ten slotte zijn ook deze verdwenen en liggen de chromosomen, die nog min of meer duidelijk hume dubbele natuur rertoonen, vijij in het protoplasma. Het is een op vallend verschijnsel, dat thans in het protoplasma rondom de chromosomen, die zich in de kermplaat rangschikken, groote alveolen gezien worden. Dit blijkt uit Fig. 13, Pl. III en zal in het volgende hoofdstuk eene nadere bespreking vinden. Evenzoo het verschijnsel, dat in de onderste spoel van Fig. 13 warneembaar is, nl. dat de helften der chromosomen het eerst uiteenwijken aan dat einde, dat niet aan de spoeldraden bevestigd is.

De bouw van de kernplaten dezer tweede deeling en de wijze, waarop de reeds bij het einde der eerste deeling ontstane helften del chromosomen uiteengaan, blijkt uit de figuren $14-17$ op Pl. III. Fig. 14 stelt eene kernplaat voor van de pool gezien. Tusschen de chromosomen is het veld donkerder tengevolge van de aanwezigheid der spoel en hier en daar ziet men ook aanduidingen van spoeldraden. Aan twee der chromosomen neemt men een V-vorm waar. Dit kan nu daardoor komen, dat het chromosoom als eene dubbele V bij de pool der eerste deeling is aangekomen, zooals ik beschreven heb, en de beide $\mathrm{V}$-vormige helften thans boven elkaar in het aequatorvlak van de spoel liggen. Maar ook is het mogelijk, dat de twee boven elkaar liggende helften van cen normaal staafrormig chromosoom ten opzichte van elkander een weinig zijn verschoven en dat daardoor de $\mathrm{V}$-vormige figuur ontstaat. In elk geval kan het ook bij deze deeling voorkomen, dat een chromosoom in zijn midden door de spoeldraden wordt 
aangevat. Dit blijkt duidelijk uit Fig. 17. Men ziet hier, hoe de helften van het ééne chromosoom aan het naar de binnenzijde van de spoel gerichte uiteinde worden aangevat, terwijl bij het andere de spoeldraden ongeveer in het midden der uiteengaande helften zijn bevestigd. Het eerste is de regel, zooals o. a. blijkt uit eene bezichtiging der in de figuren 15 en 16 afgebeelde spoelen. Bij * in Fig. 16 merkt men echter een chromosoom op, dat gebogen is en zeer wel in zijn midden aan een bundel spoeldraden bevestigd kan zijn.

Naar aanleiding van hetgeen ik bij de spoelen der eerste deeling waarnam, heb ik het vermoeden geuit, dat in elk hunner de chromosomen van één paar in hun midden door de spoeldraden worden aangegrepen. Het is nu niet onwaarschijnlijk, dat hetzelfde bij de spoelen der tweede deeling het geval is. Dit zou dan overeenstemmen met hetgeen reeds in 1900 door Strasburger ${ }^{\text {l) }}$ voor enkele planten is beschreven. Hij deelt namelijk mede, dat in de prophase van de tweede deeling de volgens de lengte gesplitste chromosomen op dezelfde plaats door de spoeldraden worden aangevat, waar zij bij het einde der eerste deeling aan deze bevestigd waren. Was een chromosoom bijv. bij de eerste deeling aan zijn uiteinde door de spoeldraden aangegrepen, dan zal dat ook bij de tweede deeling weer het geval zijn. Evenzoo heeft eene aanhechting in het midden bij de eerste deeling eene dergelijke bij de tweede ten gevolge. Hieruit volgt nu, dat, wanneer mijn vermoeden juist is, dat bij Spinacia bij de eerste

1) E. Strasburger. Ueber Reduktionstheilung, Spindelbilaung, Centrosomen und Cilientildner im Pfhnzenreich. Hist. Beitr., Heft VI, Jena, G. Fischer, 1900. 
decling één chromosoom in zijn midden wordt aangegrepen, dit ook bij de tweede deeling het geval moet zijn. Dit zou dan een argument zijn voor de continuïteit der trekdraden, voor hume aanwezigheid onk in den rusttoestand der kernen, alhoewel men ze dan niet kan waarnemen. Op dit punt kom ik echter in de volgende $\S$ terug.

Eene spoel der tweede deeling wordt ook door Fig. 18, Pl. III. weergegeven. De chromosomen wijken hier in twee groepen naar de polen uiteen en in het aequator. vlak blijven, evenals bij de eerste deeling, slechts weinig doorloopende spoeldraden over. Het hoogst liggende en in de figuur dan ook het donkerst geteekende chromosoom in elle groep is klaarblijkelijk in zijn midden ann de trekdraden bevestigd. I Iet heeft nl. een V-vorm, hetgeen vooral in de onderste helft der figuur duidelijk is. Het valt op, dat deze spoelen in dit stadium in het algemeen forscher zijn, dan zoolang de kernplatit nog aanwezig is.

Thans verdwijnt langzamerhand de phragmoplast der eerste deeling en, wanneer de chromosomen bij de polen zijn aangekomen, zooals in Fig. 19, Pl. III is geteckend, is daarvan niets meer te zien. In de moedercellen zijn nu vier groepen van 6 chromosomen aanwezig en tusschen deze bevindt zich dicht plasma, waarin men onregelmatig verloopende spoeldraden kan zien. Nog steeds kan men waarnemen, dat één der chromosomen in elke groep een V-vorm heeft. Dit blijkt bijv. in de meest linksche groep in Hig. 19, waar men op het eerste gezicht 7 chromosomen meent te zien. Inderdaad zijn er echter slechts 6, maar cen er van is V-vormig (bij a) en doet zich daardoor voor als twee. Tusschen deze chromosomen treden nu weer alveolen 
op (Fig. 20, Pl. III), die allengs grooter worden en hen ten slotte omgeven. Dan zijn de kernen der stuifmeelkorrels gereed. De korrels zelven ontstaan door eene tetrade-deeling der moedercellen. Aanvankelijk kunnen de chromosomen in de kernen compact blijven, of wel er treden alveolen in op en zij verdeelen zich tot een netwerk. In Fig. 21 en 23, Pl. III zijn die alveolen nog nict duidelijk te zien; wel echter in Fig. 22.

$\mathrm{Na}$ eenigen tijd deelt zich nu de primaire kern van de stuifmeelkorrel en wordt op de bekende wijze eene generatieve cel gevormd. Ik nam waar, dat deze zich reeds in de anthere van den wand der stuifmeelkorrel los maakt en dan vrij in de cel komt te liggen. Dit geschiedt op dezelfde wijze als STRAsBURGER ${ }^{1}$ ) voor Lilium heeft beschreven. Langzamerhand wordt de aanhechtingsplaats van de generatieve cel aan den wand der korrel kleiner. Daarbij dringt deze kleine cel dieper in de pollenkorrel door en ten laatste snoert zij zich geheel van den wand af. Nooit heb ik in de antheren stuifmeclkorrels met twee generatieve cellen gevonden en ik vermoed derhalve, dat ook hier de deeling van de generatieve cel eerst in de stuifmeelbuis plaats grijpt.

Ten slotte nog een enkel woord over de ontwikkeling der embryozakken. Deze leverde geene bijzondere verschijnselen op en verloopt geheel normal. Zovals gewoonlijk ontstaat een embryozak met 8 kernen en vindt eene dubbele bevruchting plaats. Dientengevolge vindt men in de kernplaten van zich deelende endosperm-kernen 18 chromosomen. Dit zijn trie aan elkan-

1) E. Strasburger. Chromosomenzahlen, Plasmastrukturen, Vererbungsträger und Reduktionsteilung. Jahrb. f. wiss. Bot., Bd. XLV, 1908. 
der gelijke stellen. Nooit nam ik waar, dat hier de chromosomen zich in groepen van drie rangschikten, evenmin als in de syndiploide kemplaten der wortels ooit groepen van vier chromosomen optreden. Meestal lagen de 18 chromosomen ordeloos door elkander. Het aantal endosperm-kernen is ten slotte slechts gering. Het voedingsweefsel bestaat ten minste grootendeels uit perisperm. Volgens Hegelmaier ${ }^{1}$ ) wordt bij Chenopodiaceae het endosperm later door het embryo geresorbeerd en is er in de rijpe zaden dus bij deze familie slechts perisperm aanwezig.

\section{$\S$ 4. Bespreking der resultaten.}

Uit de beschreven waarnemingen volgt, dat bij $\mathrm{S}$ pinacia o leracea eene parallele conjugatie der chromosomen gedurende de synapsis plaats grijpt. Zij bevestigen dus de opratting, die door STRAsBurger, GrÉGOIRE en talrijke andere onderzoekers wordt gehuldigd en die IÏ̈(KER ${ }^{2}$ ) met den naam „Junktionstheorie" bestempelt. In $\S 1$ van dit hoofdstuk hebben wij echter gezien, dat ten opzichte van ondergeschikte punten nog geene volkomen overcenstemming tusschen de aanhangers dezer leer is bereikt. In de eerste plats bestaat nog geen zekerheid over de vraag, of de chromosomen in een doorloopend dubbel spireem gerangschikt zijn. In

1) HeGelmaIER. Unters. ïber die Morphologie des Dikotylen-Endosperms. Geciteerd in ENGLer en Prantl. Die natiirlichen Pflanzenfamilien. III. 'Teil. 1. Abt. a, p. 49.

$\left.{ }^{2}\right)$ V. Häcker. Die Chromosomen als angenommene Vererbungstriiger. Ergebnisse und Fortschritte der Zoologie, herausgegeben von Spengel. Bd. 1, 1907. 
de tweede plaats is de aard der elementen, die tijdens de synapsis met elkander paren, aan verschil van meening onderhevig. Ten derde is het de vraag, of slechts eene paring dezer elementen zonder versmelting plaats heeft, dan wel, of de chromosomen in de prophase der reductiedeeling niet alleen paren, maar bovendien ineensmelten. Ten aanzien van alle drie deze punten geven de resultaten van mijn onderzoek der reductie-deeling van Spinacia een antwoord.

Op de vraag, of de chromosomen in een doorloopend dubbel spireem zijn gerangschikt, dan wel zich nooit met hunne uiteinden vereenigen, geven vele der nieuwste verhandelingen geen beslissend antwoord. Zoo laten Overton en LUNDEGIRDH de mogelijkheid open, dat bij verschillende van de door hen bestudeerde gewassen een doorloopende kerndraad aanwezig is. Rosenbera echter neemt bij Crepis virens niet slechts één maar meerdere spireemdraden waar en acht het dus waarschijnlijk, dat de chromosomen zich bij deze plant niet tot één doorloopend spireem vereenigen. Ook bij Spinacia heb ik geen aanduiding van een doorloopenden kerndraad kunnen vinden. Vóór de synapsis waren zeer dikwijls 6 banden, ieder met twee vrije uiteinden, zichtbaar (Fig. 8, 9 en 11, Pl. I), en na de synapsis deden zich ook geen verschijnselen voor, die er op konden wijzen, dat eene segmentatie van een spireem zou plaats grijpen.

Wat het tweede punt betreft, neemt GRÉGorRE, zooals wij gezien hebben, aan, dat uit het netwerk van de rustende kern parallele fijne draden worden gedifferentieerd, die zich bij het intreden van het synapsis-stadium aaneenleggen, om eerst weder uiteen te wijken, nadat zij uit het kluwen als dubbele draden te voorschijn 


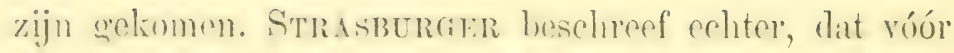
de symapsis dikke ophoopingen van chnomatine optreden, die hij s:annsomen noemele. In het kluwen-stadium narderen deze slechts tot elkander en spinnen zich tot dumne draden uit, om eerst veel later te copuleeren. Als gevolg daarvan treden uit het synapsis-kluwen nu eens twee naast elkander liggende dunne draden, die nog ineensmelten moeten, dan weer dubbele draden, warrin deze incensmelting reeds heeft plaats gehad.

Bij S pinacia zag ik in vroege praesynaptische staliën unesu dichte ophonpingen vam chromatine, zoudat er dus geen gamosomen, in een met dat der chromosomen overexnstemment aantal, aanwezig zijn. Overeenkomstig met hetgecen door Grifions is beschreven, zag ik fijne parallele dratlen optred(n, warop) van afstand tot afstand chromatine-korrels zichtharar waren. I)ezedraden naderden tot elkander, en daardoor ontstonden banden, die ieder twee chromosonen restegenworrdighlen. IIun antal was het generatieve. Reeds voordat het synapsis-kluwen zich begon te vormen, was dus de copulatie begonnen. Uit het kluwen traden later dikke draden te voorschijn, die hoe langer hoe duidelijker cene overlangsche splitsing gingen vertoonen.

(Onmiddellijk vomlat hot symapsis-kluwen ontstaat, zag ik dikwijls bij S p in a c i a, dat deze 6 lichamen, die dus ieder twee chromosomen vertegenwoordigden, veel korter waren dan de lissen, die later uit het kluwen te voorschijn zouden komen (Fig. 11, Pl. I). Deze lichamen komen hierin overeen met de zygosomen van ŚTRAsburger, mair verschillen er in dit opzicht van, dat hier blijkens de voorafgaande stadiën de beide chromosomen van elk paar reels ineengesmolten zijn, terwijl zygosomen uit twee naast elkander liggende, 
maar niet gecopuleerde gamosomen bestaan. Volgens STRASBURGER strekken deze zich naast elkander tot gamomiten en smelten ecrst dan ineen. De lichamen, die ik bij Spinacia vóór de synapsis waarnam, strekken zich na het kluwen-stadium eveneens in belangrijke mate, evenals zygosomen dat doen. Men kan dus zeggen, dat het verlonp der reductie-verschijnselen bij Spinacia in overeenstemming is met de waarnemingen van STRASBURGer, maar eveneens met die van GRÉGOIRE, omdat reeds in de vroege prophase fjne parellele draden met elkander paren.

Uit mijne waarnemingen en uit eene studie der literatuur meen ik dus te mogen besluiten, dat de ineensmelting der chromosomen op versehillende tijdstippen kan beginnen. Heeft eene plant in haar vegetatieve kernen sterk ontwikkelde prochromosomen en komen deze ook in de moedercellen voor, waarin zij dan gamosomen genoemd worden, dan zouden deze zich geheel op de wijze, als in 1905 door STrasburger en zijne leerlingen beschreven is, eerst tot fijne draden kunnen uitspinnen, alvorens te copuleeren. Hetzelfde zou in amtere planten zonder of mot kleinere prochromosomen het geval kunnen zijn, indien eene moedercel slechts een kort ruststadium doorloopt, nadat zij ontstaan was, en dus de chromosomen niet volledig in den rusttoestand waren overgegaan. Bij planten, in wier moedercellen echter om de een of andere reden tijdens den rusttoestand geen chromatine-massa's van aanzicnlijke afmetingen, maar slechts een zeer fijn netwerk voorkomt, zooals ook bij Spinacia het geval is, zou dan de kans grooter zijn, dat fijne draden optreden, die reeds zeer spoedig tot copulatie overgaan, waarbij dan al of niet dikkere lichamen kunnen ontstaan, 
die met zyosomen rergelijkbaar zijn. In de pollenmoedercellen van $\mathrm{Sp}$ in a cia heerscht nu in de verschillende cellen in dit opzicht een zekere graad van veranderlijkheil, die er voor pleit, dat de berloelde typen van elkander niet wezenlijk verschillen.

Op de derde vraag, of de chromosomen in de prophase der reduetie-deeling niet alleen paren, matr bovendien ineensmelten, heb ik hiermede terens het antword gegeren. Daar GrÉGoIre de copulatie tusschen de fijne drarlen in het zygonema-starlium ontkent, heb ik in het bijzonder ook op de paring der draden in de prophase der reductie-deeling gelet. Ik zag, dat de chromatinekorrels, die op de parallele linine-draden tegenover elkander gerangschikt waren, met elkander rersmolten (Fig. 7, Pl. I.) De dikkere plekken in de banden, die daardoor ontstonden, kunnen niet verklaard worden door het om elkander gestrengeld zijn der beide chromosomen, die een band vormen. Ik wees er ook reeds op, dat een dusdanige band eene groote overeenkomst rertoont met het beeld, dat de typische deeling van een smal chromosoom oplevert. Verder wil ik er hier aan herinneren, dat de overlangsche helften van een chromosoom, dat zich in de prophase eener vegetatieve kerndeeling heeft gedeeld. dikwijls om elkander gestrengeld zijn. Dit verschijnsel is dus niet „absolument caractéristique de la prophase hétérotypique", zooals (xRÉciolne meent. Dit is ook daarom van beteekenis, omdat JANssens ${ }^{1}$ ) er eene "Théorie de la Chiasmatypie" aan heeft vastgeknoopt, volgens welke dr ehromosomen in de prophase ran eene heterotype deeling hij humne omstrengeling geheele stukken zourlen omwisselen. Het komt

1) Zie: La Cellule, Bd. XXV, Juli, 1909. 
mij voor, dat het winden van twee chromosomen om elkander in de prophase van de reductie-deeling of van de helften van één chromosoom in de prophase van eene typische deeling een mechanisch rerschijnsel is, zonder verdere physiologische beteekenis.

Bij Spinacia nam ik, zooals ik reeds gezegd heb, eene ineensmelting waar ran chromatine-korrels, die op de parallele linine-draden paarsgewijze tegenorer elkander gerangschikt waren. De vraag doet zich nu voor: hoe komen die korrels juist tegenorer elkander te staan, voordat de versmelting intreert? In het vorige hoofdstuk heb ik de meening uiteengezet, dat de zoogenaamde chromomeren tengevolge van mechanische oorzaken ontstaan en bij regetatieve deelingen, zoowel in moederals in dochter-chromosomen, alleen dan optreden, wanneer deze smal zijn en weinig chromatine bevatten. Treden nu bij Spinacia in het leptonema-stadium der reductie-deeling toch dergelijke chromomeren op? Maakt zich toch een streven kenbaar van de stoffelijke dragers der erfelijkheid, om zich tot hoogere eenheden te vereenigen in verband met de verdere deelingsverschijnselen? Dit komt mij niet waarschijnlijk voor. Ik herinner hier aan hetgeen GRÉGOIRE zegt, naar aanleiding van het feit, dat ook hij bij de door hem bestudeerde planten in het leptonema-stadium zoogenaamde chromomeren waarnam ${ }^{1}$ ). „Les chromomères situés le long des filaments ne sont pas des corpuscules autonomes, des unités morphologiques nettement définies, mais bien des tractus plus épais et plus chromatophiles situés sur le filament chromosomique. Ces renflements chromatiques doivent s'expliquer, au moins en partie, comme dûs à un

1) 1. c., 1907 , p. 408. 
étirement subi par les filaments et leur correspondance d'un filament à l'autre trouve probablement son explication dans le fait que cet étirement n'est subi par les filaments que lorseu' ils sont déjà intimement rapuruchés: cette élongation est done subie par eux d'une façon identique". Dit kan nu bezwaarlijk eene verklaring daarvoor geven, dat bij Spinacia in de rroegste prophase de chromatine-korrels gepaard optreden. Haar wij moeten bedenken, dat ook de oorzaken, waardoor in vegetatieve kernen de homologe chromosomen paren plegen te vormen, onbekend zijn, en verder, dat ook de prochromosomen dikwijls gepaard zijn. Hieruit blijkt dus, dat, wamneer van de twee chromosomen van een par een deel is gealveoliseerd, het zichtbar blijrende deel in vele gevallen eveneens homoloog is. Maar dan ligt het voor de hand om te vragen: waarom zouden dan in de prophase van de reductie-deeling ook niet „des tractus plus épais et plus chromatophiles" van beide chromosomen, dank zij hunne ons onbekende homologie, tegelijkertijel on geparard zichthatar worden? Deze beschouwing pleit m. i. tegen de opvatting van deze lichaampjes als chromomeren.

Ook bij de overlangsche splitsing der lissen na het pachynema-stadium heb ik bij S p in a c i a geen aanduiding van de anwezigheil ran chromomeren groien. In verband met de mechanische verklaring van het ontstaan der chromomeren, die ik in het vorige hoofdstuk gaf, is eene modedecling van LuxdEGiRnu belanyrijk. Waar hij over de splitsing der dubbele draden na de synapsis spreekt, zegt hij: ${ }^{1}$ ) ${ }_{n}$ Wie bei Trollius konnte ich auch bei Matricaria die Anwesenheit eines in

1) 1. c., p. 110 . 
Chromomeren zerteilten Spirems knnstatieren. Dagegen habe ich immer eimen glatten und anscheinend homogenen Kernfaden bei Achillea und Anthemis gefunden." "Das Spirem ist bei Matricaria sehr düinn und lang und durchsetzt den Kern in vielen Krïmmungen und Schlingen." Ook hier treden dus slechts bij smalle chromosomen chromomeren op. Dit pleit roor de gegeven verklaring.

Enkele opmerkingen moren hicr in verband met mijne waarnemingen aan S p in a c i a nog plaats vinden.

In de cerste plats is de diakinese hier merkwaardig, omdat de beide leden van de verschillende paren van chromosomen elkander in meerdere of mindere mate los kunnen laten. Er kunnen $\mathrm{V}$-vormige en $\mathrm{O}$-vormige paren ontstaan en de beide leden rau cen parr kunnen zelfs geheel ran elkander scheiden (Fig. 14-18, Pl. II). Dit is een verschijnsel, waarop in den laatsten tijd in het bijzonder door STrasburger is gewezen en wel o. a. voor Thymelaeaceae $^{1}$ ) en voor Urtica ${ }^{2}$ ). In extreme gevallen kunnen zelfs alle paren in hunne beide componenten uiteenvallen. Dit kan verklaren, dat GeERTs bij Oenothera Lamarckiana na de synapsis het vegetatiere auntal chromosomen weer zag optreden. ${ }^{3}$ )

In het bijzonder verdient ook de aandacht, dat de paren ran chromosomen zeer dikwijls tot onmidrdellijk voor de diakinese in stervorm blijven samenhangen.

1) E. Strasburger. Zeitpunlet der Bestimmung des Geschlechts, Apogamie, Parthenogenesis und Reduktionsteilung. Hist. Beitr., Heft VII, 1909, p. 73.

2) E. Strasburaer. Sexuelle und apogame Fortpflanzung bei Urticaceen. Jahrb. f. wiss. Bot., Bd. 47, 1910, Heft 3, p. 246.

3) J. M. Geerts. Beiträge zur Kenntnis der Cytologie und der partiellen Sterilität von Oenothera Lamarckiana. Rec. des Trav. Bot. Neerl, Vol. 5, 1909. 
Ik meen, dat zich hierdoor het ontstaan van kettingen van achter elkinder gerangsihikte chromosomen, zooals die loor Mryske roor Giltonia en Tradescantia zijn beschreven, op eenroudige wijze laat rerklaren. Stelt men zich nl. vour, dat in dit stervormige stadium eenige paren, in plaits van naar het periphere cinde, naar het centrum toe hume componenten laten uiteenwijken, en daarbij aan elkander verbonden blijven, dan kunnen daardoor recksen van achter elkatr geplatate chromosomen ontstaan. Naar mijne meening moct deze wijze van ontstaan ook voor de kettingen gelden, die door GATES lij Oenothera rubrinervis zijn watrenomen en die volgens hem het gevolg daarvan zijn, dat de chromosomen gedurende de synapsis achter olkaar gerangschikt waren, zoorlat de paren, overeenkomstign de opvatting van FArmer en zijne school, door ombuiging zouden moeten ontstaan.

Ik ga nu over tot een tweede punt. Het komt mij nl. voor, dat de wijze, waarop de paring der elementen in le praesynaptisehe starlien bij Spinacia plaats grijpt, in staat is eenig licht te werpen op de controverse, die nog omtrent do reductie-deeling heerscht.

Aan het einde van de eerste $\S$ van dit hoofdstuk heb ik er op gewezen, dat GATES zich voorstelt, dat er in het plantenrijk twee typen van reductie-deeling gevonden worden. Bij een deel der onderzochte planten zou zij volgens de reeds genoemde Junktionstheorie, bij een ander deel volgens de z.g. F a lt u $\mathrm{ng} \mathrm{s}$ h e orie plaats hebben. Ik wees er reeds op, dat dit, met het oog op het groote gewicht van het verschijnsel, niet aannemelijk is. Hier mogen nog ecnige verdere argumenten volgen.

In de eerste plaats hebben de anhangers der beide 
richtingen zeer dikwijls dezelfde planten onderzocht. Voor deze kan dus blijkbaar slechts één der opvattingen de juiste zijn. Dit wekt het vermoeden, dat zulks ook wel voor die soorten het geval zal zijn, die slechts door één der partijen werden bestudeerd. Verder schijnen mij de afbeeldingen, die door voorstanders van de Junktionstheorie gegeven worden, in den regel beter bewijzend voor hunne opvatting te zijn, dan die van de aanhangers der Faltungstheorie voor de hunne. Men vergelijke bijv. de figuren, die Yamanodchi voor $\mathrm{Fucus}$ tot laatstgenoemde theorie doen overhellen, terwijl hij voor Nephrodium eene paring vóór de synapsis heeft beschreven.

Wat mij nu een belangrijk resultaat van mijn onderzoek der reductie-deeling bij Spinacia schijnt te zijn, is, dat de elementen, die vóór de synapsis met elkander paren, zeer fijne draden zijn. Mogelijkerwijze is dit een punt, dat aan de andacht der aanhangers van de Faltungstheorie is ontsnapt, ten minste in sommige gevallen. Ik denk hier in het bijzonder aan het feit, dat thans drie onderzoekers voor het geslacht $\mathrm{O}$ en othera hebben gemeend, dat hier de reductie-deeling volgens het schema van FARMER verloopt. Toch is dit m.i. volstrekt niet bewezen. In de eerste plaats vermoed $i k$, dat hier in vroege praesynaptische stadiën draden copuleeren, die nog fijner zijn, dan die bij Spinacia. Dit besluit ik uit Fig. 3, Pl. VI, uit de figuren 8 en 9 op Pl. XII van GEERTS' onderzoek ran de reductie-deeling bij $\mathrm{O}$ e nothera Lamarckiana, en verder uit Fig. 10, Pl. XLI van de verhandeling van DAvis over 0 . grandiflora. De banden, die men in deze figuren ziet, zijn vergelijkbaar met die, welke ik voor Spinacia 
heb afwebeeli. Slonhts zijn zij minder duirlolijk, hetoeen ik daaraan toeschrijf, dat het door deze onderzoekers verkozen chroom-osmium-azijnzuur misschien geen zoo geschikt lixatic-midel rour vroege praternaptiche strueturen is, als de alcohol-ijsazijn, die ik bij S p i n a c i a gebruikte. Ik houd het er dus voor, dat ook bij $\mathrm{O}$ en thera eene paring van elementen in de prophase der reductie-deeling plaats heeft. Dat na de synapsis hier het vegetatieve aantal chromosomen optreedt en deze in reeksen achter elkander gerangschikt kunnen zijn, is geen bezwaar tegen deze opvatting, zooals ik boven reeds uiteengezet heb.

Overigens ben ik van oordeel, dat $\mathrm{O}$ on othera ween onovertreffelijk material voor het bestuderen der reductie-deeling oplevert. Hiervan heb ik mij persoonlijk overtuigd.

Als laatste punt van bespreking wensch ik eene hypothese op te stellen omtrent den aard der trekdraden. Naar mịne meening zijn deze trekdraden continu en blijven zij in den rusttoestand der kernen bestaan, hoewel zij dan onzichtbaar zijn. Ik besluit dit nit de volgende reeds genoemde watrnemingen bij s s pinacia. 'Ten ecrste treden in de prophase van de reductie-decling donkere korreds, die tegen den nucleolus liggen, op, watrhem trlkens een paar parallel liggende linine-draden zich schijnt te begeren. Later ontstat het synapsis-kluwen bijna steeds tusschen den nucleolus en den kernwand en dringt dus den nucleolus naar het linnenste gedeclte ran de kern. Daarbij blịven kluwen en nucleolus opvallend met elkander verbonden. 'Ten tweede worlen bij de homoiotype deeling de chromosomen steeds op dezelfde plaats door de trekdraden aangevat, als bij de heterotype deeling het greval was. 
Wat het eerste argument betreft, moet ik nog vermelden, dat ik mij voorstel, rat de trekrlraden bij het einde van de deeling, waardoor de kern van de moedercel ontstond, door den zich vormenden nucleolus werden omgeven. Evenals de chromosomen lagen zij daarbij in paren. Dientengevolge loopen zij ook later in de prophase der reductie-deeling in paren naar den nucleolus.

In de literatuur zijn verder verschillende argumenten te vinden, die m. i. voor eene continuiteit der trekdraden pleiten. In het bijzonder heb ik hier de mededeelingen over polariteit op het oog. Zoo zegt Grégolne, waar hij de prophase der rerluctie-deeling in de spore-moedercellen van Osmunda bespreekt: ${ }^{1}$ ) "On voit des filaments minces nettement orientés vers un pôle du noyau". "Ils sont groupés deux par deux et déjà quelques-uns sont associés intimement et entrelacés". En verder wijst hij er op, dat dit is: ") "le premier exemple, dans les plantes, de cette polarité si nette des filaments lepto-zyğotènes". Dit verschijnsel laat zich uitstekend door eene continuiteit der trekdraden verklaren.

Eene dergelijke waarneming deed Yamanouchi bij Nephrodium ${ }^{3}$ ). Evenzoo toont eene afbeelding van de prophase der deeling van eene pollen-moedercel van Calendula officinalis (Fig. 40), die LunDEGARDI geeft, paren van draden, die naar den rand van den nuclcolus loopen, evenals ik dat bij Spinacia heb beschreven. Verder wijst Harper *) op een ver-

\footnotetext{
1) 1. c., 1907, p. 378 .

2) 1. c., 1907, p. 388 .

3) 1. c., p. 20 .

4) R. A. HARPER. Sexual reproduction and the organization of the muclei in certain mildews. Publ. Carnegie Institution, Washington $\mathrm{N}^{\circ} .37,1905$.
} 
band tusschen de plaats, waar het synapsis-kluwen ontstaat, en het centrosoom bij F ung i.

Ik meen dus te mogen besluiten, dat eene hypothese omtrent de continuiteit der trekdraden recht van bestaan heeft. 


\section{H O OF D T UK VI.}

\section{DE ROL DER VACUOLEN BIJ DE KERNDEELINGEN.}

\section{§1. Waarnemingen bij Spinacia oleracea.}

Bij het bestudeeren der deelings-verschijnselen in Spinacia heb ik in het bijzonder mijne aandacht aan den aard der kernmembraan en het gedrag der chromosomen bij het intreden en het verlaten van den rusttoestand geschonken. Het komt mij voor, dat vacuolen daarbij eene belangrijke rol spelen, en ik zal trachten dit in deze paragraaf nader viteen te zetten. Vrij algemeen wordt aangenomen, dat de vacuolen van volwassen cellen ontstaan uit alveolen van het cytoplasma, dat in meristematische cellen de kern omgeeft. Zoo zegt Koernicke ${ }^{1}$ ): "gehen doch die Vacuolen aus Waben des Alveolarplasma hervor, welche sich vergrössern, abrunden und zur Bildung grösserer Safträume mit einander verschmelzen". WENT heeft echter ontdekt, dat in meristematische cellen juist zulke vacuolen voorkomen, als in volwassene, en dus zijn de zoogenaamde alveolen in werkelijkheid kleine vacuolen die ieder door een tonoplast omgeven zijn, evenals die der oudere cellen,

1) M. Koernicke. Der heutige Stand der pflanzlichen Zellforschung. Ber. d. D. Bot. Ges., Bd. XXI, 1903, p. (68). 
en die dezelfde eigenschappen hebben als deze. Deze belangrijke ontrlekking vormt het punt van uitgang' voor de nu rolgende beschouwingen over den bouw der kernen en chromosomen en, in verband daarmede, over hunne deelings-verschijnselen.

Beginnen wij onze bespreking met de vraag: Wat is de aard van de kernmembraan? Hoe wordt zij na eene deeling gevormd; hoe verdwijnt zij, wanneer cene kern zich begint te deelen?

Voor het bestudeeren van het ontstaan van den kernwand bij Spinacia zijn de vegetatieve deelingen niet zeer doelmatig, daar de chromosomen een zeer dicht kluwen vormen, wanneer zij bij de polen zijn aangekomen. Beter kan men zich daartoe wenden tot

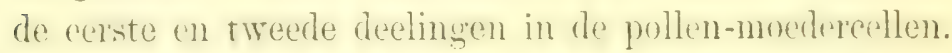

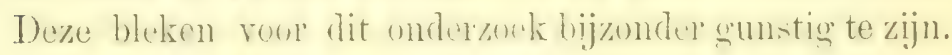

Wanneer bij de cerste deeling de rolgens de lengte gesplitste chromosomen aan de polen der spoel zijn aangekomen, liggen zij eerst dicht tegen elkander (fig. 7, Pl. III.) Spoedig echter ontstaan tusschen hen alveolen, waardoor zij van elkander gedrongen worden (fig. 8, Pl. III.) Hoe kan dit verschijnsel verklaard worden? Aanvankelijk is de groep der chromosomen geheel dor protoplasma omgeren, waarin talrijke grontere zoowel als kleinere vacuolen voorkomen, zoodat het de bekente schumstructur heeft. Daarnit treden tussehen de chromosomen alveolen op, die zich in niets van de alveolen van het omgerende plasma onderscherden. Ilieruit mag men afleiden, dat in het plismat tusschen de bij de pool aangekomen chromosomen anvankolijk exn aantal zeer kleine vacuolen aanwezig waren, die nu beginnen op te zwellen en de chromosomen uiteeu drukken. Deze. laatsten behourden daarbij hume gedaunte en laten slechts 
hunne beide overlangsche helften een weinig verder uiteenwijken. Tusschen hen zijn in fig. 8 een aantal fijne lijnen zichtbaar. Dit zijn de wanden der bedoelde vacuolen. Allengs worden deze nu grooter en ten slotte omgeven zij de chromosomen, die ook daarbij geen merkbare veranderingen ondergaan. Op deze wijze ontstaat de wand der dochterkernen. Dit nam ik in alle bestudeerde moedercellen waar. Nooit zag ik, dat poolstralingen op eenigerlei wijze medewerkten, om de kernmembraan te vormen, zooals men wel aanneemt. Daaruit besluit ik derhalve, dat de kernwand een tonoplast of racuolewand is en dat het kernsap met het celvocht te vergelijken is.

$\mathrm{Nu}$ doet zich de vraag voor, of men zich moet voorstellen, dat de kernholte uit één enkele vacuole of uit meerdere aaneensluitende bestaat. Om een antwoord te vinden, beschouwen wij de lijnen, die in de aangehaalde Fig. $S$ op Pl. III tusschen de chromosomen gezien worden. In de figuren 9 en 10, die de dochterkernen gedurende de interkinese voorstellen, zijn deze verdwenen. Twee verklaringen daarvan zijn mogelijk: of de wanden der vacuolen zijn zoo dun geworden, dat men ze niet meer ziet; in dit geval zou er slechts schijnbaar één groote vacuole, nl. de kernholte zijn. Of de verschillende oorspronkelijk tusschen de chromosomen aanwezige vacuolen zijn werkelijk tot één groote ineengesmolten. Neemt men aan, dat de wanden zijn blijven bestaan, dan is het duidelijk, waarom de chromosomen aan eene bepaalde plaats in de kern gebonden zijn. Neemt men echter aan, dat zij verdwenen zijn, en dat dus de chromosomen rrij in de kernholte komen te liggen, dan zou men tot hypothesen over de geaardheid ran het kernsap zijne toevlucht moeten nemen, om te verklaren, waarom de 
chromosomen niet door de zwaartekracht gedwongen worden, zich in een bepaald deel van de kernholte te verzamelen. Ten slotte zou men ook kunnen overwegen, dat de wanden voor een gedeclte kunnen verdwijnen, terwijl er tusschen de vacuolen nog plasmadraden overblijven, die met de plasma-armpjes in rolwassen cellen vergelijkbaar zijn.

Wanneer de dochtenkernen der tweede deeling ontstaan, kan men dezelfde verschijnselen waarnemen. Weer worden de chromosomen, die aanvankelijk dicht tegen elkander bij de polen der spoel lagen (Fig. 19 op $\mathrm{Pl}$. III), door in volumen toenemende vacuolen van elkanler gedrongen (Fig. 20, Pl. III). Deze omgeven hen ten slotte en vormen zoo den kernwand, zonder dat de chromosomen daarbij cene merkbare verandering ondergaan (Fig. 21, Pl. III). Ook hier is het duidelijk, dat eene poolstraling bij het ontstaan der kernmembraan geen rol kan spelen. Later, in de dochterkernen, zijn er tusschen de chromosomen geen plasma-verbindingen meer te zien. Dit moet wederom of daardoor verklaard worden, dat de wanden tusschen de verschillende vacuolen, die de kernholte deden ontstaan, te dun werden, om nog zichtbaar te zijn, of daardoor, dat zij werkelijk verdwenen zijn, zondat de vacuolen zich met elkander tot één groote vacuole, de kernholte, vereenigden.

Bij het begin eener kerndeeling speclt zich, zooals te verwachten is, het omgekeerde proces af. Het verdwijnen ran de kernmembraan in de prophase eener deeling is nicts ander's, als het kleiner worden van de vacuolen, die de chromosomen omgeven, waardoor deze laatsten ten slotte vrij in het protoplasma komen te liggen.

In Fig. 1 op Pl. III is dit voor de kern van eone 
pollen-moedercel van Spinacia, die juist het diakinesestadium verlaten heeft, afgebeeld. Men ziet, dat de paren van chromosomen nog dezelfde gedaante hebben, als in de diakinese. Het protoplasma dringt tusschen hen in, terwijl alleen in het midden nog eenige open plekken overgebleven zijn. Dit zijn de kernvacuolen, die allengs kleiner worden. Ten slotte zijn hare afmetingen zoo gering, dat men zeggen kan dat de paren der chromosomen vrij in het protoplasma liggen. Tegelijk ontstaat de spoel, waarbij men slechts geringe aanduidingen van een multipolairen oorsprong waarneemt.

Hetzelfde verschijnsel herhaalt zich, wanneer de dochterkernen zich gaan deelen (Fig. 11 en Fig. 12 op Pl. III). Langzamerhand wordt de kernholte kleiner; er treden tusschen de chromosomen plasmaverbindingen op, die klaarblijkelijk wanden van kernvacuolen zijn, en het plasma dringt tusschen de chromosomen in. Ten slotte zijn de lichte plekken tusschen hen verdwenen. De kernvacuolen hebben hun volumen tot een minimum teruggebracht en de chromosomen liggen dus vrij in het protoplasma.

Wanneer de kernmembraan verdwijnt en de kernholte kleiner wordt, ziet men tusschen de chromosomen weer plasmaverbindingen verschijnen, die wanden van vacuolen zijn. Dat deze thans weer optreden, verhoogt de waarschijnlijkheid, dat de kernholte niet één enkele holte was, maar uit talrijke aaneensluitende vacuolen met onzichtbare dunne wanden bestond. Was de kernholte slechts één vacuole, dan zou men moeten aannemen, dat aan het kleiner worden der vacuolen deelingen voorafgingen. In het andere geval worden eenvoudig de onzichtbare, doch feitelijk aanwezige wanden weer duidelijk. 
Verder pleit, naar ik meen, voor de opvatting van den kernwand als tonoplast en van de kernholte als een complex van vacuolen het volgende verschijnsel.

Iramneer eene pollenmoedercel in het stadium der diakinese rerkeert, ziet men in haar cytoplasma slechts zeer kleine vacuolen. Zoodra zij zich echter in een deelings-stalium bevindt en de chromosomen in de kernplaat liggen of op weg zijn naar of aangekomen zijn bij de polen der spoel, zijn in het protoplasma der cel de vacuolen groot geworden (Fig. 7, Pl. III). Dit nu is gemakkelijk te begrijpen, zoo men de kernmembraan als tonoplast en de kernholte als een samenstel van vacuolen opvat. Want het grooter worden van de vacuolen in het cytoplasma kan dan ten koste van de kernvacuolen geschied zijn. '/ijn later de dochterkernen der eerste deeling ontstaan, dan neemt men in het cytoplasma wederom slechts kleine vacuolen waar. Gaan zij zich echter opnieuw deelen en is hun wand verdwenen, dan zijn de vochtholten van het plasma weer groot geworden. Dit ziet men bijv. in Fig. 13 op pl. III. Zijn eindelijk de dochterkernen dezer tweede deeling' gereed, dan zijn de alveolen van het plasma weer klein geworden en in de jonge stuifmeelkorrels is dit laatste dan ook fijnmazig. Hieruit volgt derhalve, dat de kernholte in volumen kan toenemen ten koste van de vacuolen van het protoplasma en omgekeerd vochten aan de laatsten kan afstaan. Dit pleit voor de opvatting van haar wand als tonoplast.

Vatten wij thans in korte woorden het tot nu toe besprokene te zamen.

De kernmembraan is een tonoplast. Bij het einde eener deeling liggen de chromosomen aanvankelijk dicht bijeen en vrij in het protoplasma. 
Dan zwellen kleine vacuolen, die in dat plasma tusschen de chromosomen aanwezig zijn, op, dringen daardoor de chromosomen uiteen en omgeven hen ten slotte. Op deze wijze wordt de kernwand gevormd. Waarschijnlijk vereenigen de verschillende vacuolen, die de kernholte doen ontstaan, zich niet tot één enkele, maar blijven hare wanden bestaan, hoewel zij te dun zijn, om waargenomen te kunnen worden. Het toenemen in volumen der kernvacuolen geschiedt ten koste van den inhoud van de vacuolen van het protoplasma. Wanneer eene kern zich gaat deelen en de kernmembraan verdwijnt, speelt zich het omgekeerde proces af. De kern-racuolen worden dan langzamerhand kleiner, waarbij zij hun vocht aan de vacuolen van het protoplasma afstaan. Ten slotte zijn zij zoo klein, dat de chromosomen vrij in het protoplasma komen te liggen. Daar, zooals WENT gevonden heeft, in één enkele cel vacuolen met verschillende eigenschappen kunnen voorkomen, is het zeer wel mogelijk, dat de kern-vacuolen zich in verschillende opzichten van de andere vacuolen der cel onderscheiden. ')

Thans ga ik tot de bespreking van een volgend punt over en zal trachten aan te toonen, dat ook in de chromosomen zelven vacuolen voorkomen, en dat deze de oorzaak zijn van de vormveranderingen, die de eersten bij het intreden en bij het verlaten van den rusttoestand ondergaan.

Voor het bestudeeren van de vormverwisselingen der chromosomen bij het einde der deelingen levert $\mathrm{S}$ p i n a c i a geen bijzonder bruikbaar materiaal. Tijdens de vegetatieve deelingen liggen deze lichamen in een te dicht kluwen en in de dochterkernen ran de eerste

1) Zie de volgende $\S$. 
deeling der stuifmeel-moedereellen ondergaan zij geen belangrijke veranderingen. Slechts in de dochterkernen der tweede deeling kan men het zoogenaamde alveoliseeren waarnemen. Dit heb ik in Fig. 22 op Pl. III afgebeeld. Aanvankelijk zijn de chromosomen kort en dik. Dan treden er echter holten in op en trigelijkertijd worden zij langer. Het is duidelijk, dat deze holten zwellende vacuolen zijn. Zij nemen in grootte toe ten koste van de overige kern-racuolen. Naar mijne meening berust nu het z. g. alveoliseeren van chromosomen na eene deeling algemeen op het grooter worden van talrijke vacuolen. Hierdoor wordt bewerkt, dat een chromosoom in een aantal vliesjes wordt verdeeld, die door wanden van vacuolen begrensd zijn, en die zoo dun kunnen worden, dat zij in den rusttoestand der kernen slechts als een zeer fijn netwerk zichtbaar zijn. Het roor het grooter worden benoodigde vocht ontleenen de chromosoom-vacuolen aan de kern-vacuolen. Door dit vacuoliseeren worden de chromosomen tot een netwerk uitgebreid en daar de randen hiervan aaneen kunnen sluiten, kan de geheele oppervlakte van eene kern één netwerk schijnen te zijn.

In de prophase eener deeling heeft nu het omgekeerde plaats. De chromosoom-racuolen staan hum rocht af aan de kernholte en worden dus kleiner. Dientengevolge trekt het chromosoom, dat in den rusttoestand netrormig was, zich samen tot ren meer compacten vorm, dien het gredurende de nu rolgende decling behoudt. Deze verschijnselen nam ik dikwijls waar. Niet allcen bij vegetatieve deelingen in meristemen van wortels en in het weefsel van jonge zaadknoppen en antheren van Spinacia, maar ook bij andere planten, o. a. in vegetatiepunten van wortels van Allium Cepa. 
Overal bevestigde zich de overtuiging, dat in de chromosomen, evenals in het protoplasma, vacuolen aanwezig zijn en dat hare veranderingen in volumen de meer of minder gedrongen gedaante der chromosomen teweegbrengen.

Naar aanleiding van deze beschouwingen wensch ik nog op de beide volgende punten te wijzen.

In de eerste plaats herinner ik aan hetgeen ik in de laatste $\S$ van het vierde hoofdstuk over de overlangsche splitsing der chromosomen in de prophase van vegetatieve deelingen gezegd heb. Men ziet dan in de chromosomen eene reeks van openingen optreden, die klaarblijkelijk deze splitsing bewerken. Na hetgeen in deze paragraaf over het voorkomen van vacuolen in chromosomen gezegd is, zal het duidelijk zijn, dat ook deze openingen als racuolen moeten worden opgevat. Door hare vergrooting ontstaan dan de beschreven alveolen, die de splitsing der chromosomen veroorzaken.

Ten tweede wil ik wijzen op het verband tusschen de hypothese van de continuiteit der trekdraden, die ik in de laatste $\S$ van het vorige hoofdstuk opstelde, en hetgeen in deze paragraaf besproken is. De chromosomen zijn bijzondere gedeelten ran den protoplast, waarin alle erfelijke eigenschappen vertegenwoordigd zijn. Dit brengt echter volstrekt niet mede, dat, zooals men klaarblijkelijk meestal aanneemt, deze gedeelten geheel van het overige protoplasma zouden afgesnoerd zijn. Dit komt mij voor, eene willekeurige en overbodige aanname te zijn. Veeleer vormen de trekdraden de verbindingen van het meer gespecialiseerde gedeelte van den protoplast, in dit geval de chromosomen, met het overige protoplasma. Dit rerband blijft steeds bestaan, ook in den rusttoestand der kernen, ofschoon men er 
dan niets van kan ontdekken. Dit kan tevens als verklaring dienen van het feit, dat in de prophase eener deeling de beide helften van ecn chromosoom op dezelfde plaats door de spoeldraten worden aangegrepen. 'Tot nu toe neemt men aan, dat bij het verdwijnen van de kernmembraan de spoeldraden van weerskinten in de kernholte binnendringen en voor een gedeelte zich aan de chromosomen bevestigen. Hierdoor kan echterm. i. niet verklaard worden, waarom zij dit slechts op é́n enkele plaats doen en wel van weerszijden juist op de overeenkomstige plaats in de beide helften van cén chromosoom.

Tot dusver hebben wij gezien, dat de kernmembraan een tonoplast moet zijn, en dat in dechromosomen vacuolen aanwezigmoeten zijn. Thans wenschiker nog op te wijzen, dat ook de verschijnselen, diezich rondom de kernin het protoplasma voordoen, wanneer eene deeling zal plaats hebben, en daarmede de spoelvorming, het spel van vacuole $n$ z ij n.

Wamneer eene kern zich in de prophase eener deeling bevindt, verandert de structur van het omliggend protoplasma. Van schuimvormig wordt het draderig. Terens verandert zijn vermogen, om zich met bepaalde kleurmiddelen te kleuren. Zoo wordt het met FLEMmra's drickleuren-methode thans violet in plaats van bruinachtig. Strasiburer ${ }^{1}$ ) heeft er op gewezen, dat

1) E. Strasburger. Ueber Reduktionsteilung, Spindelbildung, Centrosomen und Cilienbildner im Pflanzenreich. Hist. Beitr., Heft VI, Jena, G. Fischer, 1900, p. 125.

Verder in E. Strasburger. Chromosomenzahlen, Plasmastructuren, Vererbungsträger und Reduktionsteiling. Jahrb. f. wiss. Bot., Bd. XLV, 1908. 
deze verandering met het verdwijnen van den nucleolus samengaat. Hij onderscheidt het schuimvormige plasma als trophoplasma en het draderige als kinoplasma. Vooral op de plaatsen, waar later de polen der spoel optreden, hoopt zich dit laatste sterk op en bij het verdwijnen van de kernmembraan doet het de spoeldraden op de bekende wijze ontstaan, rerschillend naarmate men deelingen van vegretatieve cellen of wel van stuifmeelof embryozak-moedercellen bestudeert.

Deze omvorming van trophoplasma in kinoplasma berust nu in hoofdzaak op het kleiner worden van vacuolen. Wanneer men zich voorsteit, dat in reeksen van vacuolen de dwarswanden verdwijnen, moeten in de praeparaten draden van protoplasma zichtbaar worden. Dit heb ik kunnen waarnemen en wel in het bijzonder bij phragmoplasten, zooals die, welke in Fig. 13 op Pl. III is afgebeeld. Tusschen twee draden ziet men dikwijls een heldere strook, somwijlen echter eene reeks van kleine holten. Verdwijnen dan de dwarswandjes tusschen deze, dan kan op deze wijze het beeld van overlangsche draden ontstaan.

In het midden moet gelaten worden, of het verdwijnen van den nucleolus slechts toevallig tegelijkertijd met het optreden van kinoplasma buiten de kern plaats grijpt of wel daarmede in causaal verband staat. In het laatste geval zou men zich kunnen voorstellen, dat osmotisch werkzame stoffen, die in den nucleolus gelocaliseerd waren, nu in het plasma worden verdeeld, waar zij dan eene verkleining der onmiddellijk om de ker'u gelegen vacuolen zouden kunnen bevorderen.

Volgens de bovenstaande beschouwingen berust het mechanisme van het kerndeelingsproces in hoofdzaak op de werking van vacuolen. In de prophase eener 
deeling worden de chromosoom-vacuolen kleiner en staan zij haar vocht aan de kernvacuolen af. Terens differentieert zich rondom de kern, door het kleiner worden der vacuolen, het schuimvormig trophoplasma tot draderig kinoplasma. Dan verminderen ook de kernvacuolen haar volumen, en ontstaat de spoel uit het kinoplasma, dat voornamelijk aan de polen der kern gelegen is. Ilierbij kunnen de plasmadraden, die nu van beide kanten tot elkander naderen, tot doorloopende spocldraden of steundraden worten, door zich met elkander te vereenigen. Dit behoeft echter niet te geschieden. Voor de trekdraden neem ik, zooals reeds gezegd is, continuiteit aan, d. w. z., dat zij steeds aanwezig zijn.

Ten slotte moge naar aanleiding van het tot dusver besprokene nog eene opmerking volgen over de beweging van de dochterchromosomen eener deeling naar de polen der spoel.

Alfred Fischer ${ }^{1}$ ) schrijft deze beweging aan groci- en bewegingsverschijnselen van het protoplasma toe. Daartegenover nemen de meeste botanische cytologen aan, dat de trekdraden het vermogen hebben, om de chromosomen naar de polen der spoel te trekken. Daartoe zouden de polen reelal rechtstreeks met den ectoplast verbonden of anders daaraan door poolstralingen als het ware opgehangen zijn. Wanneer de trekdraden korter worden, nemen zij echter niet in dikte toe. Daarom neemt STrasburgER aan, dat hunne verkorting op een verlies van substantie berust. ${ }^{2}$ ) ${ }_{n}$ So wie diese

1) Alfred Frscher. Fixierung, Fürbung und Bau des Protoplasma. p. 252 .

2) 1. c., 1900, p. 142. 
Fasern bei ihrer Anlage Nukleolarsubstanz für ihr Wachstum verwenden, so geben sie jetzt diese Substanz wieder ab und verkürzen sich damit gleichzeitig".

Bij het bestudeeren van pollen-moedercellen van Spinacia heb ik nu nooit waargenomen, dat de polen der spoelen aan den ectoplast vastgehecht waren. Evenmin zag ik ze er door poolstralingen zóó mede verbonden, dat de pool als een vast punt in de cel en dus als steunpunt voor trekkende krachten kon beschouwd worden. Daarom kan ik van de algemeen gehuldigde opratting slechts overnemen, dat de verkorting der trekdraden op verlies van substantie berust, en meen ik, dat deze stof aan het overige protoplasma van de cel wordt afgegeven. Volgens de in deze paragraaf gegeven uiteenzetting staan toch protoplasma, trekdraden en chromosomen in voortdurende wisselwerking. De bewerging der laatsten naar de polen moet dus wel overeenkomstig Fischer's opvatting uit bewegings- en groeiverschijnselen van het protoplasma verklaard worden. Twee mogelijkheden komen hierbij in aanmerking.

Eenerzijds zou men kunnen aannemen, dat protoplasma-stroomingen, die voorbij de polen der spoel gaan, het verlies van substantie in de trekdraden teweeg brengen. Dit zou kunnen verklaren, waarom in den regel de helften van een chromosoom daar beginnen uiteen te wijken, waar de trekdraden zijn aangebracht.

Eene tweede mogelijkheid is, dat vacuolen door haar spanningen medewerken om de chromosomen naar de polen te dringen. Dit zou men bijv. kunnen afleiden uit de onderste spoel, die in Fig. 13 op Pl. III is afgebeeld. Hier toch ziet men, dat de paren het eerst aan hunne vrije uiteinden uiteen gaan wijken, hetgeen 
niet door ene contractic der trekdraden on dus slechts door eene werking van vacuolen verklaard kan worden. Verder is de in Fig. 18 op Pl. III afgebeelde spoel der tweede deeling, warin de chromosomen op weg naar de polen zijn, van pool tot pool gerekend, langer dan de spoelen, die in de figuren 15 en 16 zijn weergegeven en waarin de chromosomen nog in de kernplaat liggen. Dit schijnt mij, op grond van een aantal metingen, die ik verricht heb, regel te zijn. Ook dit kan niet door eene contractic der trekdraden verklaard worden, doch wel door een toenemen in volumen van tusschen de beide uiteengaande complexen van chromosomen gelegen vacuolen.

\section{\$2. Vacuolen in meristematische cellen.}

Het komt mij voor, dat de opvatting, dat de verschijnselen der kerndeeling in hoofdzaak op de werking van vacuolen berusten, eene groote vereenvoudiging beteckent. Daarom zal ik nu uit de literatuur cen aantal argumenten aanhalen, die mij toeschijnen voor deze opvatting te pleiten. Daarbij zal ik eerst het voorkomen en de beteekenis van vacuolen bespreken, en het mededeelen van cytologische argumenten tot eene volgende $\S$ uitstellen.

De in de vorige paragraaf ontworpen toepassing van de leer der vacuolen op de kerndeelingen gaat uit van de ervaring, dat in meristematische cellen vacuolen worden aangetroffen, die van cen eigen wand zijn voorzien, en dezelfde cigenschappen hebben, als die der volwassen cellen. Zij berust verder op het feit, dat in 
eenzelfde cel vacuolen van verschillenden aard kunnen voorkomen.

Onze kennis van de vacuolen in meristematische cellen steunt op de onderzoekingen van WENT 1). Zij doen zich daar even zoo voor als in volwassen cellen, doch zijn in den regel zeer klein en in grooten getale aanwezig. WENT onderzocht de initiaal-cellen van stengels en wortels van Phanerogamen, de topcellen van Kryptogamen, zeer jeugdige cellen van wieren en fungi, embryozakken, eicellen, pollenkorrels en cambiumcellen. Overal trof hij vacuolen aan en wel meestal meerdere in één enkele cel. Slechts in de topcel van vele Kryptogamen en in de eicel der Phanerogamen zag hij dikwijls slechts één groote vacuole. Om deze vochtblazen waar te nemen, is het meestal voldoende de praeparaten in eene $5 \%$ suikeroplossing te brengen. Dat zij ook in deze cellen in het bezit zijn van een eigen wand, toonde WENT aan, door van het volgende verschijnsel gebruik te maken.

Wanneer men eene volwassen cel met eene $10 \%$ oplossing van kaliumnitraat plasmolyseert, kan het gebeuren, dat de beide buitenste lagen van den protoplast afsterven, terwijl alleen de tonoplast zich contraheert. Is de cel ongekleurd en had men bij de salpeteroplossing een weinig eosine gevoegd, dan kan men in dit geval de vacuole als eene kleurlooze blaas in de roode vloeistof zien liggen, terwijl de beide buitenste lagen van het protoplasma zich intensief kleuren. Dit

1) F. A. F. C. Went. De jongste toestanden der vacuolen. Dissertatie, Amsterdam, 1886.

Les premiers états des vacuoles. Arch. Néerl. des Sc. ex. et nat., 1887.

Die Vermehrung der normalen Vacuolen durch Theilung. Jahrb. f. wiss. Bot., Bd. XIX, 1888. 
verschijnsel berust daarop, dat de tonoplast aan den dovdelijken invloed van verschillendo reagentia grooteren weerstand biedt, dan de buitenlaag en het korrelige protoplasma.

Over den aard van dezen weerstand heeft VerschaFFELT ${ }^{1}$ ) onderzoekingen gedaan. Is de buitenste laag van den protoplast tegen de inwerking van eene $10 \%$ oplossing van salpeter bestand, zoodat de cel normaal geplasmolyseerd wordt, dan kan men de isoleering der vacuolen bewerken, door den geheelen protoplast eerst te verzwakken. Dit kan bijv. door het aanwenden eener hoogere temperatuur geschicden. Hoe hooger deze is, des te korter behoeft zij te werken, om ten gevolge te hebben, dat bij plasmolyse slechts de tonoplast zich contraheert. Hieruit blijkt, dat de tonoplast na de verwarming de werking van de plasmolyseerende vloeistoffen verdraagt, ofschoon de buitenste laag van het protoplasma dit dan niet meer kan. Minder schadelijke oplossingen, zooals die van glycerine, beschadigen in gewone omstandigheden de buitenste lagen niet en deze contraheeren zich dus mede. Door eene voorafgaande inwerking van hooger temperatuur kan men die lagen echter zoo verzwakken, dat ook in die oplossingen alleen de tonoplast zich samentrekt. Dezelfde resultaten, als met hoogere temperatuur, kan men bereiken door het onthouden van zuurstof of van voedsel en door verschillende andere schadelijke invloeden.

WENT liet eene met eosine gekleurde $10 \%$ salpeteroplossing op meristematische cellen inwerken. De beide buitenste lagen van het protoplasma stierven daarbij

1) E. VERSCIAFFeLT. Over weerstandsvermogen van het protoplasma tegenover plasmolyseerende stoffen. Botau. jaarb. uitgeg. door het kruidk. Gen. Dodonaea te Gent, III, 1891. 
af en kleurden zich rood, terwijl de vacuolen in leven bleven en als kleurlooze blaasjes in de roode massa lagen. Door eene zachte drukking kon hij ze uit het gekleurde plasma te voorschijn laten treden. Verwarmde hij daarna het praeparaat onder het microscoop, dan zag hij de blaasjes plotseling barsten, zoodra de temperatuurgrens van het leven bereikt werd.

Uit het aangehaalde blijkt, dat reeds in de jongsto cellen vele kleine vacuolen met een eigen wand of tonoplast aanwezig zijn. Past men dit op jonge kernen toe, dan moet men het zeer wel mogelijk achten, dat na eene kerndeeling, als de chromosomen bij de polen der spoel gelegen zijn, kleine vacuolen tusschen hen voorhanden zijn en door hun opzwellen de kernmembraan vormen. Evenzoo valt de mogelijkheid niet te ontkennen, dat in de chromosomen zelven eveneens vacuolen aanwezig zijn en dat deze het z.g. alveoliseeren veroorzaken.

In het bijzonder wil ik er op wijzen, dat van deze vacuolen de wand als het primaire en de inhoud als het secundaire beschouwd moet worden, niettegenstaande dit in tegenstelling is met de opvatting van PFEFFER ${ }^{1}$ ). Deze toch meent, dat overvloedig opgenomen imbibitiewater zich in druppelvorm te midden van het protoplasma zou verzamelen en dat dit er dan een wand om zou afzetten. Om deze meening te staven, geeft hij eene afbeelding van een wortelhaar van Hydrocharis morsus ranae, dat in water opengedrukt is. In het uitgevloeide protoplasma treden nu groote vacuolen op, en wel volgens PFEFFER tengevolge van de uitscheiding van overvloedig opgenomen imbibitiewater. Met min-

1) PFEFfer, Pflanzenphysiologie, p. 92, fig. 6. 
stens evenveel recht kan dit verschijnsel echter aan een opzwellen van reeds vorhanden vacuolen toegeschreven worden en hiermede is de mededeeling van PfeFfer in overeenstemming, dat de genoemde blazen in plasmolyseerende vlocistoffen niet ontstaan. Deze toch zouden, ingeval men met een imbibitie-verschijnsel te doen had, eveneens vacuolen te voorschijn roepen.

In volwassen cellen hebben de vacuolen het vermogen om zich in kleinere te deelen en om met elkander ineen te smelten. Een fraai voorbeeld hiervan leveren de z. g. aggregatie-verschijnselen in de tentakels van Drosera, die door DARWIN zijn ontdekt. Wanneer tengevolge van den een of anderen prikkel de klieren tot sterkere afscheiding overgaan, kan men in de cellen van klier en steel voornamelijk drie veranderingen waarnemen $\left.{ }^{1}\right) ; 1^{\mathrm{e}}$ eene versnelde circulatie van het wandstandig protoplasma; $2^{\ominus}$ eene deeling van de vacuole in kleinere en $3^{\text {e }}$ cene belangrijke vermindering van het volumen dezer vacuolen. Hierbij laten deze een deel van haren inhoud in het protoplasma treden, maar de roode kleurstof en bepaalde opgeloste eiwitten blijven in de vacuolen. Als de prikkelwerking heeft opgehouden, vergrooten deze zich weer, smelten ineen en le cel keert tot den oorspronkelijken toestand terug.

Een ander goed voorbeeld levert het ontstaan der aleuronkorrels. WAKKER ${ }^{2}$ ) vond bij planten, die in het bezit van zulke korrels zijn, dat in de cellen

1) DE VRrEs. Ueber die Aggregation im Protoplasma von Drosera rotundifolia. Bot. Ztg., 1886 p. 1.

2) J. H. WАKKER. Aleuzonkorrels $\approx$ jin vacuolen. Maandblad voor nat. wet., 1886, No. 7 en 1887, No. 5 en 6 ; Bot. Centr. bl., Bd. XXXIII, No. 12; Studien über die Inhaltskörper der Pflanzenzellen. Jahrb. f. wiss. Bot., Bd. XIX, 1888, p. 423. 
van het rijpende endosperen de groote vacuole zich in talrijke kleinere deelt en dat deze eiwit in zich ophoopen. Op deze wijze ontstaan de aleuronkorrels. Bij het ontkiemen wordt het eiwit opgelost en smelten de kleine vacuolen weer tot grootere ineen.

Volgens WENT hebben ook in meristematische cellen deelingen en versmeltingen van vacuolen plaats. Om dit te zien behoeft men jonge cellen slechts in suikeroplossingen van $3-5 \%$ te onderzoeken. Bijzonder gunstig hiervoor vond hij de hyphen van fungi. Dezelfde waarneming deed hij echter bij jonge stuifmeelkorrels, bij haren, initiaalcellen van stengels en wortels, enz. Fraaie voorbeelden van deelingen van vacuolen vindt men verder in de onderzoekingen van denzelfden schrijver over het ontstaan van deze organen in de voortplantingscellen der wieren. $\left.{ }^{1}\right)$ Wanneer uit eene moedercel talrijke zwermsporen gevormd worden, terwijl er aanvankelijk slechts ééne vacuole aanwezig was, ziet men deze zich zoo door deeling vermenigvuldigen, dat elke zoospore er ééne kan krijgen.

Het feit, dat reeds in jeugdige cellen de vacuolen met elkander kunnen versmelten, geeft aan de verklaring van het ontstaan van kinoplasma als gevolg van het ineensmelten van reeksen van kleine vacuolen voldoenden steun.

Een ander belangrijk punt, dat hier besproken moet worden, is, dat in eenzelfde cel vacuolen van verschillenden aard kunnen voorkomen. Duidelijk is dit vooral, wanneer een der vacuolen een gekleurd celvocht bevat,

1) F. A. F. C. Went. Die Vacuolen in den Fortplanzungszellen der Algen. Bot. Ztg., 1889 en Die Entstehung der Vacuolen in den Fortpflanzungszellen der Algen. Jahrb. f. wiss. Bot., Bd. XXI, 1890. 
doch de orerige niet. zooals dit bij vele bloembladeren het geval is. Een voorbeeld hiervan leveren de bloemen van Camellia, die mede door Wext werden bestudeerd. Hier ligt in het milden van elke cel cen rood celvocht en daaromheen meerdere kleine kleurlooze z.g. adventieve vacuolen. Het gekleurde celvocht vertoont bovendien eene ractic op looistof. Onderzoekt men uu jonge nog kleurlooze bloembladeren, dan blijkt, dat de looistof reeds dan in de middelste vacuole aanwezig is. Op nog jongere stadiën zijn de verschillende racuolen ook in dit opzicht niet van elkander te onderscheiden. Dit $\mathrm{nu}$ is voor ons doel zeer belangrijk. Vacuolen, die op cen jeugdig stadium in niets van elkander schijnen af te wijken, kumnen later toch verschillende eigenschappen hebben. Evengoed is het dus mogelijk, dat kleine vacuolen, die tusschen en om de chromosomen liggen, wanneer deze na eene deeling bij de polen der spoel zijn aangekomen, zich tot kern-vacuolen differenticeren en zich daarbij in verschillende opzichten van de overige vacuolen der cel onderscheiden.

Naar amleiding hiervan kan de vraag opgeworpen worden, of men moet aannemen, dat deze kern-vacuolen afzonderlijke vacuolen mot bijzondere eigenschappen zijn, dan wel of de gewone vacuolen der cel onder bepaalde invloeden die eigenschappen kunnen aannemen. In het eerste geval zou men zich moeten voorstrllen, dat bij cene kerndceling de klein geworden kerm-vacuolen zich met de chromosomen naar de polen begeven en daar opnieuw opzwellen. In het tweede geval zourlen telkens willekeurige vacuolen ran het protoplasma onder den invloed der chromosomen kunnen komen en daarbij tot kernvacuolen worden.

IIet laatste komt inij het meest waarschijnlijk voor, 
daar voor deze opvatting gewichtige argumenten pleiten. Zoo komen volgens WENT in de bloembladeren van Glycine sinensis witte en blauwe vacuolen voor, die door alle overgangen met elkander zijn verbonden. Dit maakt het onwaarschijnlijk, dat voor elke kleurschakeering een bijzondere tonoplast aanwezig zou zijn. Een krachtig argument levert ook het volgende. Wanneer men eene witbloeiende variëteit van eene roode soort met het stuifmeel der laatstgenoemde bevrucht, pleegt in den bastaard de roode kleur te domineeren. De vacuolen van den bastaard ontstaan echter uit die van de eicel der moederplant en deze zouden bij zelf bestuiving slechts ongekleurde nakomelingen geven. Blijkbaar brengt dus de mannelijke geslachtskern de eigenschap voor de kleur mede en worden de vacuolen van den bastaard door deze beïnvloed. Hiermede vergelijkbaar is het volgende voorbeeld, dat door DE VRIES ${ }^{1}$ ) genoemd wordt. Wordt eene plant, die niet het vermogen heeft, om in haar vacuolen appelzuur te vormen, bestoven door eene andere, die dat vermogen wel heeft, zoo komt dit zuur toch in de vacuolen van den bastaard voor. Dit is dan klaarblijkelijk door de aan wezigheid van de mannelijke kern veroorzaakt.

In de opgenoemde voorbeelden veranderen vacuolen hare eigenschappen onder den invloed der celkernen. Wij mogen dit dus ook voor de vacuolen der celkernen zelven aannemen.

1) De VRIEs. Intracellulare Pangenesis, 1889, p. 198. 


\section{§3. Cytologische argumenten.}

Wanneer men de nieuwere cytologische literatuur met het oog op eene mogelijke rol van vacuolen in de kernen bestudeert, ontmoet men tal van figuren en waarnemingen, die roor deze voorstelling pleiten. IIet is onmogelijk, om alle argumenten hier bijeen te brengen, doch ik acht het van belang ten minste enkele daarvan aan te voeren.

In de eerste plaats wijs ik er op, dat reeds te voren een onderzoeker heeft medegedeeld, dat in sommige stadiën der kerndeeling binnen de deelingsfiguur vacuolen zijn waar te nemen. SxpKess ${ }^{1}$ ) zegt voor de deeling van de rrije kernen in het protoplasmatische wandbelegsel van den embryozak van Fritillaria imperialis: "Wenn die Kermmembran ganz oder teilweise verschwunden ist, sehen wir den Kernraum mit einer körnigen Masse gefüllt, die der umgebenden dichtkörnigen Protoplasmazone gleich ist." "Oft befinden sich in der körnigen Masse innerhalb des Kernraumes auch kleine, aber deutliche und scharf begrenzte Vakuolen." Deze vacuolen komen m. i. overeen met de klein greworden kernvacuolen, die ik bij Spinacia waarnam.

In de tweede plaats spreekt Sypkens over het binnendringen van vacuolen in de spoel na afloop der deeling. In het protoplasma, dat de spoel omgeeft, zijn talrijke racuolen roorhanden. Narlat de dochterkernen eener deeling gevormd zijn, wordt het verband tusschen deze en het complex der verbindingsdraden verbroken. Diar ter plaatse verschijnt nu protoplasma met vacuolen

1) B. Sypkens. Die Kernteilung bei Fritillaria imperialis. Rec. des trav. bot. Néerl., 1904, p. 33. 
in steeds toenemende hoeveelheid. Van de plaats, waar het het eerst optrad, dus van de dochterkernen uit, dringt dit plasma nu naar het aequatorvlak door. „Ohne Zweifel", zegt Sypkexs ${ }^{1}$ ), „stammt dieses Protoplasma mit seinen Vakuolen, das in der Teilungsfigur sichtbar wird, aus dem umliegenden Protoplasma". Daar derhalve "die Vakuolen, die sich in bestimmten Stadiën innerhalb der Teilungsfigur befinden, dort nicht entstehen, sondern anderwärts schon vorhanden waren", is dit in overeenstemming met de opvattingen van DE VRIES en WeNT. Hieraan sluit zich het boven beschreven optreden van vacuolen tusschen de chromosomen, narlat deze bij de polen der spoel zijn aangekomen, op eenvoudige wijze aan.

Verder ontstaat volgens verschillende schrijvers de kernmembraan zonder de medewerking van poolstralingen. Dit is geheel in orereenstemming met mijne waarnemingen bij Spinacia. Zoo beschrijft LAWson ${ }^{2}$ ), dat in de telophase van de heterotype deeling van pollen-moedercellen van Passiflora en in die van de deelingen der spore-moedercellen vau Equisetum limosum tusschen de chrumosomen vochtholten optreden, die grooter worden en daarbij de chromosomen uiteendringen. Wanneer het kernvocht ten slotte met het cytoplasma in aanraking zou komen, zou dit laatste tot de vorming eener membraan overgaan, die dus ran cytoplasmatischen oorsprong zou zijn. Hieruit rolgt, dat de vermelde holten vacuolen moeten geweest zijn. Deze moeten echter reeds van den beginne af een eigen wand bezeten hebben, want juist de wand stelt eene vacuole in staat, om zich te vergrooten. De onder-

1) B. SYPKENS. 1. c., p. 53.

2) Anstrother A. Lawson. On the relationship of the nuclear membrane to the protoplast. Bot. Gaz., Bd. XXXV, 1903. 
stelling, dat het protoplasma der eel zich door eene membraan tegren de vochtholte zou begrenzen, wordt daardoor geheel overbodig.

Op dezelfde wijze ontstaat volgens GréGoIre en WIJGAERTS ${ }^{1}$ ) de kernmembraan bij Trillium. Bij het einde eener deeling vormen de chromosomen cen "tassement polaire", waarbij zij elkander zijdelings aanraken ${ }^{2}$ ) „C'est en ce moment que l'on voit apparaître, entourant et baignant l'ensemble chromosomique, le liquide qui constituera l'enchylème du futur noyau. Il augmente rapidement, déterminant (comme nous le verrons) la formation de la vacuole nucléaire et de sa membrane".

Dit heeft tengevolge, dat de chromosomen zich van elkander verwijderen, en daarbij nemen de genoemde auteurs anastomosen tusschen hen waar. Deze beschouwen zij als draden, welker ontstaan een gevolg zou zijn van de voorafgegane aanraking in verband met eene visqueuse natuur der chromosomen. De mogelijkheid, dat op deze wijze bij het uiteengaan der chromosomen draden gevormd worden, is natuurlijk niet te ontkennen. Waarschijnlijker is het echter, dat de hedoelde anastomosen niet anders zijn, dan de wanden van de vacuolen, die de kernholte zullen doen ontstaan. Grégorre en Wygaerts vergelijken zelven echter deze vochtholten niet met echte vacuolen en meenen, even als LAwson, dat de kernmembraan eerst later ontstaat door "une condensation périphérique du cytoplasme autour de l'enchylème nucléaire" ${ }^{3}$ ).

1) Victor Grégorre et A. WiJgaerts. La veconstitution du noyau ct la formation des chromosomes. La Cellule, 'T. XXI, Fase. I, 1903.

$\left.{ }^{2}\right)$ 1. c., p. 16 en 17 .

3) l. c., p. 27. 
Bij Allium ontstaat volgens GrÉGorre ${ }^{1}$ ) de kernmembraan op dezelfde wijze. Evenzoo beschrijft MarTINS MANO ${ }^{2}$ ) het optreden van vochtholten tusschen de chromosomen bij het einde eener deeling. Zoo zegt ook Berans ${ }^{3}$ ) voor Paris quadrifolia: "Le liquide nucléaire se dépose entre les chromosomes et les sépare. Il se forme ainsi la vacuole nucléaire, se distendant dans le protoplasme qui l'entoure de toutes parts". EscoYez ${ }^{4}$ ) beschrijft hetzelfde voor de kerndeeling van Zygnema.

Ten slotte wil ik er nog op wijzen, dat ook volgens Gates 5) bij het ontstaan van de dochterkernen der heterotype deeling bij Oenothera tusschen de chromosomen vochtholten optreden. "The nuclear membrane appears where the karyolymph comes in contact with the cytoplasm. The nucleus so formed is at first very small, but grows rapidly to its full size by the increase in nuclear sap." Van de vloeistof zelve zegt hij, dat „it must remain uncertain whether the karyolymph is secreted by the chromosomes or merely attracted and accumulated about them from the cytoplasm." Volgens de in dit hoofdstuk outwikkelde opvatting moet natuurlijk het laatste het geval zijn.

1) Victor Grégoire. La structure de l'élément chromosomique au repos et en division dans les cellules végétales (Racines d'Allium). La Cellule T. XXIII, Tase. 2, 1906.

2) Thomaz Martins Mano. Nucléole et Chromosomes dans le meristème radiculaire de Solanum tuberosum et Phaseolus vulgaris. La Cellule, T. XXII, Fasc. 2, 1905.

3) J. Berghs. Le fuseau hétérotypique de Paris quadrifolia. La Cellule, T. XXII, Fasc. 1, 1905, p. 209.

4) Eud. Escoyez. Le noyau et la caryocinèse chez le Zygnema. La Cellule, T. XXIV, Fasc. 2, 1907.

5) R. R. Gates. The behavior of the chromosomes in Oenothera lata $\times$ O. gigas. Bot. Gaz., Bd. XLVIII, No. 3, Sept. 1909. 
Zon zouden meerdere roorbeelden zijn aan te voeren, waarin het optreden van vochtholten tusschen de chromosomen bij het einde cener deeling is waargenomen, evenals ik dit voor Spinacia beschreven heb. In verband met de opratting ran DE TRIES, WENT en vele andere onderzoekers omtrent den bouw der planteneellen, moet dit overal een opzwellen van reeds voorhanden vacuolen beteekenen. De tonoplast moet er zijn, om het grooter worden der vochtholte te kunnen bewerken. In verband hiermede moet de kernmembraan als tonoplast beschouwd worden. De opvatting; dat zij als product van het protoplasma optreedt, waar dit met het kernsap in aanraking komt, zooals dit in de borengenoemde onderzoekingen algemeen wordt aangenomen, moet derhalve vervallen.

De stelling, dat ook in de chromosomen zelven vacuolen voorkomen, is in overeenstemming met de ervaringen omtrent den bouw der kernen van VAN Wisselingil ${ }^{1}$ ), Grégoire, Wygaerts en anderen. In het bijzonder hebben GrÉgoire en WyaAERTS het zoogenaamde alveoliseeren der chromosomen bij het overgaan in den netrormigen toestand na eene deeling bestudeerd. IIunne figuren voor Trillium en Allium pleiten op overtuigende wijze voor mijne meening, dat het alveoliseeren aan het grooter worden van vacuolen moet toegeschreven worden. Hier moge er nog slechts op gewezen worden, dat de chromosomen in den rusttoestand niet uitsluitend een alveolairen bouw vertoonen.

1) C. vaN Wisselingh. Ueber den Nukleolus von Spirogyra. Bot. Ztg., 1898; Ueber das Kerngeriist. Bot. Ztg., 1899; Ueber Kernteilung bei Spirogyra. Flora, 1900; Untersuchungen über Spiroyyra. Bot. Ztg., 1902; Ueber abnormale Kernteilung. Bot. Ztg. 1903; Ueber die Karyokinese bei Oedogonium. Beih. z. Botan. Centr. bl., 1907. 
"D'autre part," zeggen Grégotre en Wygaerts ") "à̀ côté de ces plages alvéolaires ou spongieuses il existe aussi, dans le même noyau, de vrais filaments, qui disparaissent rapidement à la vue, lorsqu'on tourne la vis micrométrique. La structure du noyau est donc à la fois alvéolaire et réticulée, bien que, nous devons l'ajouter, le noyau présente plutôt dans son ensemble un aspect alvéolaire." De verklaring hiervoor geven zij zelven reeds. ${ }^{2}$ ) "Mais de plus, à l'intérieur même des bâtonnets, l'alvéolisation en progressant peut amener la rupture de certaines membranules et leur transformation en parties plus ou moins filamenteuses ou lamellaires." Dit verschijnsel laat zich in verband met mijne opvatting der alveolen als vacuolen zeer goed verklaren. Deze toch kunnen zich zoo met elkander vereenigen, dat gedeelten van den vroegeren scheidingswand als draden behouden blijven. Zoo moet men zich toch ook de protoplasma-armpjes ontstaan denken, die somwijlen in volwassen cellen waargenomen worden en die nog voor korten tijd uitvoerig door Lidforss onderzocht werden.

Uit deze en vele andere onderzoekingen, die ik nog zou kunnen aanhalen, wordt het derhalve zeer waarschijnlijk, dat in de chromosomen algemeen vacuolen voorkomen, en dat deze de oorzaak zijn van de vormveranderingen, die de eersten bij het intreden en bij het verlaten van den rusttoestand ondergaan.

Ook voor de opvatting, dat het optreden van kinoplasma in de prophase eener deeling en de vorming der spoel veroorzaakt worden door een kleiner worden van

2) 1. c., p. 12.

1) 1. c., p. 31 . 
vaeunlen, gepaard met ineensmeltingen van deze laatsten, kunnen talrijke argumenten uit de literatuur angevoerd worden.

Yoo ontstaat bij Pollia volgens GrÉGotre en Berghs 1) in de prophase eene draderige structuur door het zich afplatten der mazen van het protoplasma in de richting der polen. Na eene deeling wordt do spoel aan den aequator breeder, de draden verwijderen zich van elkander en gaan, nadat de celplaat en de nieuwe wand ontstaan zijn, weer in het mazige protoplasma over. Deze verandering van het netwerk in drarden geschiedt allengs. Wanneer men aanncemt, dat de mazen van het cytoplasma ook hier vacuolen met een eigen wand ziju, moet dit dus eene verkleining van het volumen dezer vacuolen tot oorzaak hebben. In deze rerhandeling bestrijden GrÉGorre en BErghs ook de hypothese van de contractie der trekdraden op grond daarvan, dat deze zich niet verdikken en dat de chromosomen zich tot aan de polen bewegen. Eene zoo sterke contractie van trekdraden is, volgens hen, ondenkbaar.

Voor Paris komt Bergis ${ }^{2}$ ) tot hetzelfde resultat. In het ruststadium toont het cytoplasma een geheel gelijkvormign netwerk. "Ce réseau donne le fuseau en perdant sa structure réticulée et en s'orientant spécialement sous l'influence des phénomènes dont le noyau et la cellule sont le siège. Il ne sert pas entièrement à former le fuseau: la zone píriphérique n'est jamais atteinte par les morlifications fusoriales; la structure réticulée y est con-

1) Victor GrÉgoIre ot J. Bergirs. La figure achromatique dans Pellia epiphylla. La Collule, T. XXI, Fasc. 1, 1904.

$\left.{ }^{2}\right)$ J. Berghs. 1. c. 1905. 
servée; mais elle reste toujours en relation directe avec celle du fuseau et passe graduellement en elle. De plus, à la fin de la division, le fuseau redevient le réseau cytoplasmique, en perdant son orientation," "Le fuseau de Paris n'est ainsi que le cytoplasme spécialement ordonné en vue de la division de la cellule." Daarbij beschrijft hij eene afplatting der mazen in de richting der polen. Ook hier berust dus klaarblijkelijk het ontstaan der spoel op de werking van vacuolen.

Bijzonder belangwekkend is eene verhandeling van Densmore ${ }^{1}$ ) over de spoelvorming bij Smilacina amplexicaulis. Hij beschrijft, dat in de wortelcellen dezer plant de mazen van het protoplasma bij de polen van de kern kleiner zijn dan elders in de cel. Aan deze polen ontstaan nu in de prophase donkere kappen, die uit zeer vele kleine mazen bestaan, welke door zich donker kleurend plasma omgeven zijn. Tegelijkertijd is de nucleolus veel kleiner geworden, zooals uit zijne figuren blijkt. Het is mogelijk, dat hierdoor de sterke kleurbaarheid van het protoplasma wordt veruorzaakt. Densione bespreekt nu de wijze, waarop uit dit kleinmazige plasma draden ontstaan. Hij zegt, dat op overlangsche doorsneden de wandjes tusschen reeksen van mazen verdwijnen. Op dwarsche doorsneden door de spoel neemt men in jonge stadiën donkere punten waar, die door lijnen tot een netwerk zijn verbonden. In latere stadiën verdwijnen ook in deze doorsneden de wanden der mazen. Men kan bovendien op overlangsche doorsneden opmerken, dat de draden gedurende dit proces

1) HIRAM D. DENSMORE. The origin, structure and function of the polar caps in Smilacina amplexicaulis. Unir, of Cal. Publ. in Botany. Vol. 3. No. 2, Dec. 1908. 
dikker worden. Ifet komt mij voor, dat hieruit duidelijk blijkt, dat het goheele verschijnsel berust: ecrst op een kleiner worden van vacuolen en daarna op het ineensmelten van deze zoowel in overlangsche richting, als rondom de kruispunten van het netwerk, dat men op dwarsche doorsmeden in jonge starliën waarneemt. Dergelijke waarnemingen schijnen mij een krachtig argument voor mijne opratting te zijn, dat kinoplasma door de werking van vacuolen, uit trophoplasma ontstaat. 


\section{SAMENVATTING DER RESULTATEN.}

Spinacia oleracea vertoont bij de vegetatieve deelingen 12 chromosomen. Deze zijn in p a ren gerangschikt, zoowel in de prophasen, als ook in de kernplaten en naar alle waarschijnlijkheid ook in den rusttoestand. Bovendien vertoonen zij duidelijke verschillen in lengte, die gedurende de opeenvolgende deelingen gehandhaafd blijven en die zich in verschillende individuen op dezelfde wijze voordoen.

In normale kiemwortels nam ik dikwijls z.g. s y nd i pl o id e cellen waar. Zij liggen somtijds alleen, somwijlen in reeksen te midden van de gewone diploide cellen en onderscheiden zich van deze terstond door hare meerdere grootte. Men treft er òf één groote kern, of twee diploide kernen of ook meerdere kleine kernen in aan. In de kernplaten van de deelingen dezer syndiploide cellen zijn 24 chromosomen aanwezig. Zij liggen hier evenals in de normalekernplaten in paren; groepen van vier worden niet waargenomen.

De overlangsche splitsing der chromosomen heeft in de vroege prophase plaats, terwijl zij nog tegen den kernwand liggen. Daarbij treedt in elk chromosoom eene overlangsche reeks van vacuolen op, die door hare vergrooting ten slotte deze splitsing bewerken. Ten ge- 
volge van de aanwezigheid dezer vacuolen vertoonen zoowel moeder-als dochter-chromosomen eene afwisseling van donkere en lichtere plekken. Dikwijls zijn daarbij humne overlangsche helften spiraalsgewijze om elkander gewonden.

In de prophase der reductie-deeling worden de 12 chromosomen als achromatische of lininedraden zichtbaar, die van afstand tot afstand verdikkingen vertoonen, welke zich door de aanwezigheid van chromatine donker kleuren. Deze draden naderen paarsgewijze tot elkander, waarbij ten slotte de verdikkingen, die in de beide draden tegenover elkander geplaatst zijn, ineensmelten. Op deze wijze ontstaan banden, die ieder twee chromosomen vertegenwoordigen en twee vrije uiteinden heblen. Een doorloopend, enkelvoudig of dubbel spireem komt dus niet voor. In dit stadium neemt men dikwijls in sommige moedercellen ecner anthere slechts cen rerward complex van dunne draden waar, maar dit moet wellicht an eene schidlelijke werking van het fixatiemiddel toegeschreven worden.

$\mathrm{Nu}$ begint de synaptische contractie. Alvorens het kluwen der synapsis geheel gevormd is, kunnen de paren van chromosomen zich minder of meer samentrekken, somtijds zelfs tot tamelijk gerlrongen lichamen. In de verschillende moedereellen heerscht echter in dit opzicht een zekere graad van verscheidenheid.

Wanneer later het kluwen der synapsis zich begint te ontwikkelen, kan een chromosomenpaar het eerst met een der vrije uiteinden uit het kluwen te voorschijn komen, maar in den regel treedt een meer naar het midden gelegen gedeelte als lis naar buiten. Zulk een lis 
bestaat dan uit twee nast elkander liggende chromosomen en is dus eigenlijk eene dubbele lis. Dit blijkt o. a. uit talrijke splijtingen. Meestal ziet men op deze wijze zes lissen ontstaan, daar dit het generatieve aantal is. Van elke lis makt zich in den regel ten slotte een der uiteinden uit het kluwen vrij; op deze wijze openen de lissen zich. Het andere uiteinde blijft dan in het midden der kern in het kluwen. Daarna heeft eene gelijkmatige verdikking en verkorting der paren plaats, waarbij de vroegere lisvorm langen tijd als knik kenbaar kan blijven. Tot onmiddellijk vóór het stadium der diakinese kunnen de paren zóó in het midden der kern in stervorm blijven samenhangen. Maar dan wordt dit rerband opgeheven en begeven zij zich naar den kernwand. Daarbij kunnen de beide chromosomen van een paar tot een 0-vorm of tot een V-vorm uiteenwijken of zolfs elkander geheel loslaten. In de embryozak-moedercellen kunnen bij de diakinese ook tetraden optreden.

De heterotype en homoiotype deelingen verloopen daarna verder, zooals dit voor andere planten bekend is. Hare studie leidde mij echter tot het opstellen der hy pothese, dat de trekdraden cont in u zijn, m.a.w. dat zij in den rusttoestand der kernen, hoewel onzichtbaar, aanwezig blijven. De phragmoplast, die na de eerste deeling tusschen de dochterkernen optreedt, ontstaat niet door eene splitsing der primair aanwezige verbindingsdraden, maar daardoor, dat het protoplasma zich o p n i e u w tot draden differentieert.

De kernmembraan is een tonoplast. $\mathrm{Na}$ eene deeling zwellen kleine vacuolen, die in het protoplasma tusschen en om de bij de polen der spoel 
aangekomen chromosomen aanwezig zijn, op, en wel ten koste van het celvocht van andere vacuolen uit het protoplasma. Zij stuwen daarbij de aanvankelijk dicht opeengedrongen chromosomen uiteen, en omgeven hen ten slotte. Daarbij ondergaan de chromosomen zelven nog geen in het ong loopende veranderingen. Op deze wijze ontstaat de kernholte, die derhalve een complex van vacuolen is. Ifet zoogenaamde verdwijnen van de kernmembraan in de prophase eener deeling berust op het omgekeerde proces.

Ook in de chromosomen zelven zijn vacuolen aanwezig. Zij veroorzaken de vormveranderingen, die deze lichamen bij het intreden en bij het verlaten van den rusttoestand ondergaan. In het eerste geral zwellen zij op en brengen daardoor teweeg, dat het chromosoom in een netwerk verdeeld wordt. In de prophase ener deeling worlen zij kleiner, ten gevolge waarvan het chromosoom cen meer gedrongen gedaante aanneent. De chromosoom-vacuolen ontleenen haar vocht voornamelijk aan de kern-vacuolen.

Eindelijk berusten ook de verandering van trophoplasma in kinoplasma en het ontstaan der spoel op het spel van vacuolen. Deze worden kleiner, overlangsche reeksen smelten tot buizen ineen en daarbij wordt het protoplasma tot draden gedifferentieerd. 


\section{N A S C H R I F T.}

$\mathrm{Na}$ het afdrukken van dit proefschrift verschenen twee verhandelingen, die op een der behandelde punten betrekking hebben. Beide knoopen aan de door Rosenberg roor Drosera longifolia en door Gates voor Oenothera gigas geuite meening vast, dat het dubbele antal chromosomen, dat in deze planten in vergelijking met hare naaste verwanten rourkomt, aan eene overlangsche splitsing toe te schrijven is. Deze meening heb ik getracht door nieuwe argumenten te steunen en zij wordt thans ook door Tahara en StrasBURGER als juist erkend.

Tahara ${ }^{1}$ ) telde bij vegetatieve deelingen in $\mathrm{Crepis}$ japonica 16 chromosomen, terwijl er volgens JUEL ${ }^{2}$ ) bij Cr. tectorum slechts 8 en volgens Rosenberg ${ }^{3}$ ) bij $\mathrm{Cr}$. virens zelfs slechts 6 voorkomen. Bij de reductie-deeling in de pollen-moedercellen van $\mathrm{Cr}$. japonica beeldt Tahara zeer duidelijk af, dat telkens twee paren van de kernplaat der eerste deeling aan clkander gelijk zijn. Dit valt gemakkelijk in het oog, omdat de paren

1) MI. TAHARA. Ueber die Zahl der Chromosomen von Crepis japonica BeNth. The Botanical Magazine, Tokyo, Vol. XXIV, Febr. 1910.

3) O. Juel. Die T'etradenteilung bei Taraxacum und anderen Cichoriaceen. Kgl. Svenska Vet.-Akad. Handlingar, 1905.

3) O. Rosenberg. 1. c., Sv. Bot. Tidskr., Bd. 3, 1909. 
in grootte en gedaante verschillen. Daaruit besluit Tamara, dat ook bij Cr. japonica in het vegetatieve leven vier gelijkwaardige stellen van chromosomen voorkomen, evenals bij de zooeven genoemde Drosera longifolia en Oenothera gigas. Het ten opzichte van soorten als Crepis tectorum verdubbelde aantal zou dus door cenc overlangsche splitsing verklaard moeten worden.

Uit zijne figuren blijkt ook, dat de overeenkomst twee aan twee tusschen de paren der kernplaat vooral berust op de wijze, waarop de trekdraden aangehecht zijn. Bij twee der paren grijpen zij zeer duidelijk in het midden aan, bij twee andere an het einde der chromosomen. Dit mag als een verder argument voor mijne hypothese van de continuiteit der trekdraden, m. a. w. voor het bestaan van een blijvend verband tusschen chromosomen en protoplasma, beschouwd worden.

Ten tweede verscheen zooeven eene verhandeling ran StrasburaEr ') onder den titel "(hromosomenzahl", in welke hij eveneens tot het resultaat lromt, dat eene verdubbeling van het aantal chromosomen door eene overlangsche splitsing mogelijk is, en dat daardoor tetraploide sporophy ten kunnen ontstaan. STRAsBURGER zegt datromtrent: „Die Warseheinlichkeit spricht dafür, dass der Ort eines solchen Vorgangs das befruchtete, noch ungeteilte Ei ist." Voor Oenothera gigas heb ik echter getracht waarschijnlijk te maken, dat de verdubbeling reeds vór de bevruchting in de kiemcellen moet zijn ingetreden.

1) E. Strasiuraer. Chromosomenzahl. Flora, Bd. 100, 1910, p. 2-50. 


\section{STELLINGEN.}

I.

De Sympetalen zijn polyphyletisch ontstaan.

II.

De Gramineeën hebben een perigoon, dat uit twee kransen bestaat. De buitenste wordt door het bovenste kroonkafje, de binnenste door de ludiculae gevormd.

\section{III.}

De diktegroei van Palmen, Pandaneeën en andere Monocotylen is geen atavistisch verschijnsel.

IV.

Bij het enten ran Solanum lycopersicum op S. nigrum kunnen door het dooreenmengen van de cellen van entloot en wildstam 6 zoogenaamde "Hyperchymären" ontstaan.

V.

Apogame soorten ontstaan als mutaties, waarbij de pangenen voor de reductie-deeling in meerdere of mindere mate in humne werkzaamheid worden belemmerd.

\section{VI.}

De resultaten, die Jomanssex met aether en Molisch met warm water bij het trekken van planten verkregen hebben, zijn eveneens donr aanwending eener lage temperatuur te bereiken. 


\section{VII.}

Een overgang van andere dan plastische stoffen van entloot op wildstam vindt niet plaats.

\section{VIII.}

De corneageencellen der Crustacecën en do hoofdpigmenteellen der pterygote Insecten zijn homoloog.

\section{IX.}

De nieren van Amphioxus moeten niet als protonephridiën, matr als Coelomolueten beschouwd worden.

\section{$\mathrm{X}$.}

De Enteropmeusten kumnen als verwijderde verwanten der Chordaten worden aangezien.

\section{XI.}

Tusschen de tegrnwondige opvattingen over praeformatie en epigenesis bestaat geen essentieel verschil.

\section{XII.}

De kraterberg van Canyon Diablo in Arizona is niet van vulkanischen oorsprong en komt in zijne ontstaanswijze met de maankraters overeen.

\section{XIII.}

De diluviale ijstijd kan niet door eene poolverschuiving verklaard worden.

\section{XIV.}

Het voorkomen van venen in de tropen is een nieuw bewijs voor de meening, dat de steenkolen in tropische klimaten kunnen ontstaan zijn. 


\section{VERKLARING DER FIGUREN.}

Alle figuren zijn ontleend aan Spinacia oleracea $\mathrm{L}$. Alle teekeningen zijn met behulp van een teeken-apparaat van Zeiss vervaardigd. Waar dit noodig was, zijn ook de fijnste linine-draden, de plasmastructuur en de overige détails met behulp van dit prisma geteekend. Steeds werd wat hooger lag, donkerder en wat lager gelegen was, lichter aangegeven. Bij elke figuur wordt de velgrooting afzonderlijk vermeld.

\section{PLAAT I.}

Fig. 1-6 hebben betrekking op embryozak-moedercellen, Fig. 7-15 op pollen-moedercellen.

Fig. 1. Nucellus van een jongen zaadknop. Het binnenste integument is juist begonnen zich te ontwikkelen. De archespoor-cel heeft zich in eene wandcel en in de embryozak-moedercel gedeeld. In de laatste bevindt zich de kern in een praesynaptisch stadium. Men ziet den nucleolus en tevens zeer fijne parallele linine-draden, die op geringe afstanden door donkere chromatische knoopjes zijn verbonden. Vergr. 500.

Fig. 2 en 3. Kelnen van embryozak-moedercellen, onmiddellijk na de synapsis. In Fig. 2 komen uit het synapsis-kluwen twee lissen en een gestrekte draad te voorschijn; in Fig. 3 twee dikkere gestrekte draden en een tweetal kleine lissen. Vergr. 1500.

Fig. 4. Laat postsynaptisch stadium. Er zijn 6 paren van chromosomen Deze zijn gemerkt a a-e en **. Het eene uiteinde van elk paal is naar den omtrek van de kern gericht, het andere einde ligt meest ongeveer in het midden. Dit heeft ten gevolge, dat in het midden nog een overblijfsel van het kluwen aanwezig is.

a a Dit parr bestaat duidelijk uit twee componenten.

$b b$ is aan het periphere einde gevorkt; hieruit blijkt zijn dubbelnatuur.

$c c$ is onregelmatig van vorm.

$e e$ laat duidelijk door splijtingen zijne dubbele natuur blijken. Dit paar is naar boven omgebogen.

$d d$ en * zijn aan het periphere einde niet alleen gerorkt, maar de beide vertakkingen zijn daar nog eens gesplitst. Vergr. 2250. 
Fig. 5. Kern tan eene embryozak-moedercel kort voor de diakinese. De paren zijn aanmerkelijk korter en dikker geworden en glijden uiteen. Het paar a vertoont nog in beide componenten eene anduiding van eene lengtesplitsing. De nueleolus vertoont een samengestelden bouw. Vergr. 2250.

Fig. 6. Diakinese. Van één paar zijn de chromosomen gescheiden en door * angeduid. Bij a eene "tetrade". Vergr. 2250.

Fig. 7-15. Pollen-moedercellen in praesynaptische stadiën, allen 2250 maal vergroot.

Fig. 7. Zeer vroeg praesynaptisch stadium. Men merkt fijne parallele linine-draden op, welke hier en daar door chromatische substantie verbonden zijn. Hier en daar ziet men echter ook gepaarde zich donker kleurende korrels op de parallele linine-draden.

Fig. 8 en 9. Iets latere stadiën. In beiden telt men 6 banden, blijkbaar elk bestaande uit twee parallele draden, waartusschen ophoopingen van chromatine liggen op vele plaatsen zijn duidelijk splijtingen te zien. In Fig. 9 toont de band $1-1$ rooral aan den rechterkant een duidelijk gevorkt einde. Er zijn een groote en een kleine nueleolus.

Fig. 10. Praesynaptisch stadium, waarin men verscheidene vrije uiteinden kan opmerken. Het is echter niet met zekerheid uit de figuur op te maken, dat er juist 12 vrije uiteinden zijn, zooals uit de aanwezigheid van 6 gepaarde chomosomen rolgen zou. De draden zijn duidelijk dubbel, daar hun deelen op vele plaatsen uiteenwijken, bijv. bij *.

Fig. 11. Begin van de synaptische contractie. Een zestal hier en daar duidelijk gespleten banden zijn zichtbaar. Die, welke met 1 en 2 gemerkt zijn, zijn aan hun rechtsche einde gevorkt.

Fig. 12. De synaptische contractie is begonnen. Twee paren van ehromosomen, met a en b gemerkt, komen goed uit en vertoonen bijzonder duidelijk hunne dubbelnatuur door gevorkte uiteinden en splijtingen.

Fig. 13. Deze kern toont de plaats, waar het synapsis-kluwen in den regel ontstaat, nl. tusschen kernwand en nucleolus.

Fig. 14 en 15. Het stadium der synapsis is bijna bereikt. Nog zijn hier en daar splijtingen in de draden waarneembaar, bijv. bij * in Fig. 14 . 

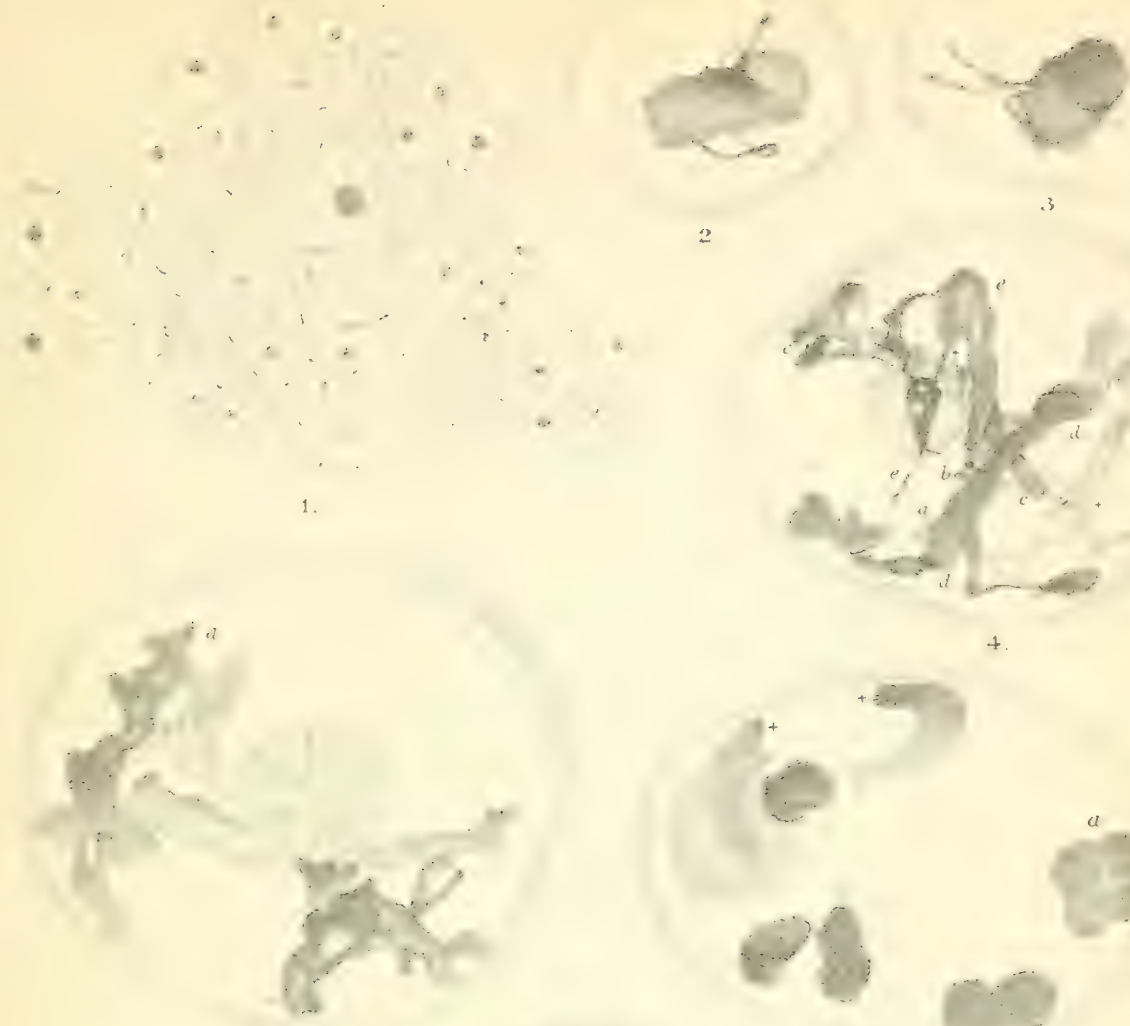

2

3
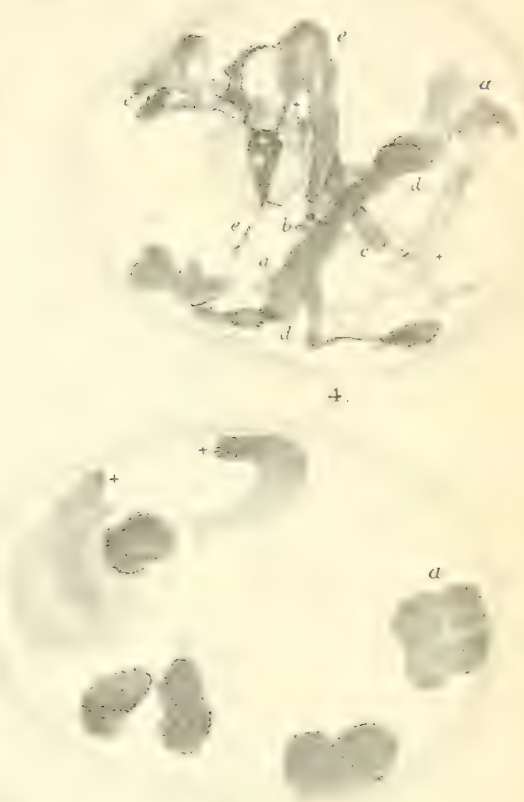

(i.
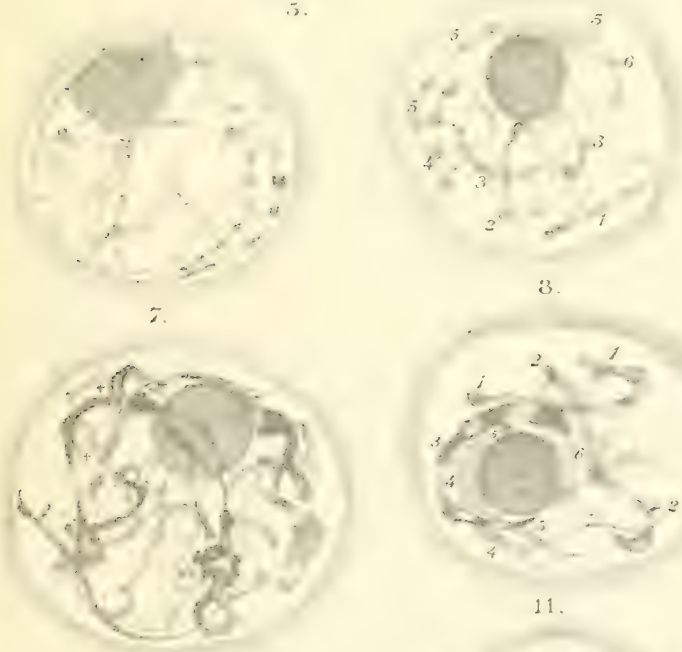

3

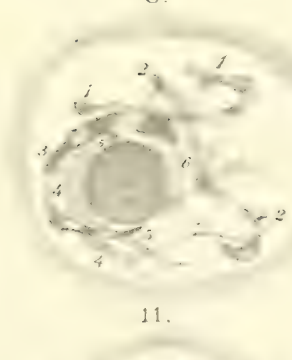

if)

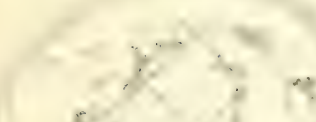

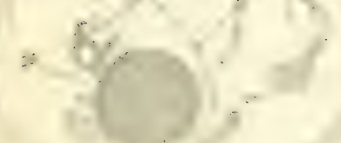
123
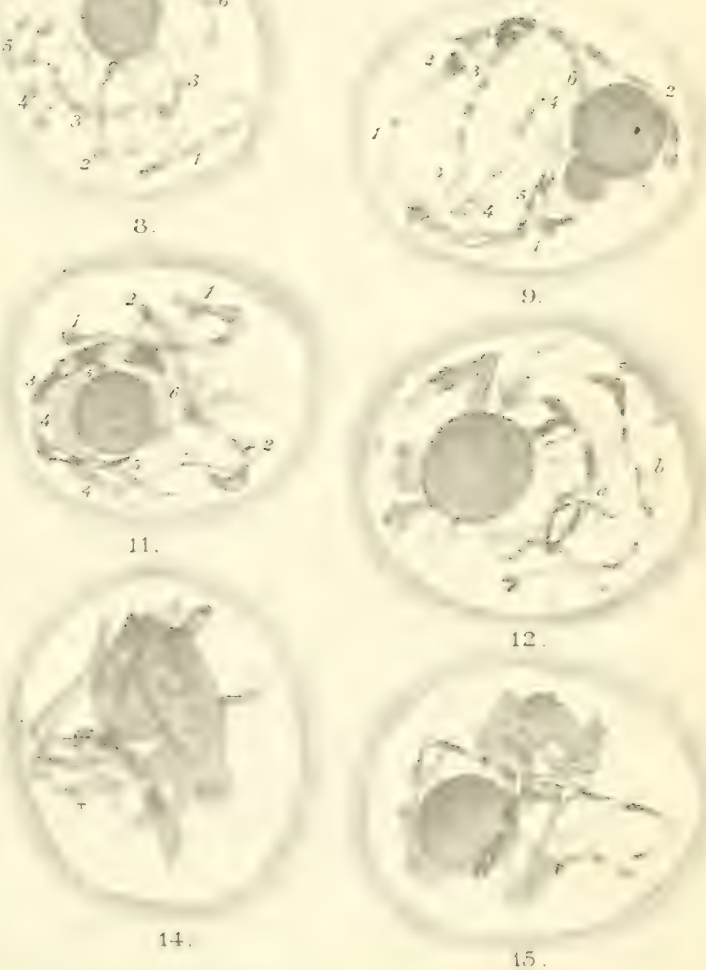



\section{PLAAT II.}

Alle figuren hebben betrekking op pollen-moedercellen.

Fig. 1. Deel van eene dwarsche doorsnede eener anthere, waarvan de moedercellen zich in het synapsis-stadium bevinden. De wand- of "tapeten"-cellen laten elkander reeds los en toonen meest twee dicht tegen elkaar liggende kernen. Vergr. 750.

Fig. 2. Postsynaptiseh stadium Het synapsis-kluwen hangt duidelijk met den nucleolus samen. Een dikke draad komt er uit te voorschijn en vertoont eene aanduiding van eene lengtesplitsing. Vergr. 1500.

Fig. 3. Een dergelijk stadium. Uit het synapsis-kluwen komen twee lissen en een gestrekte draad te voorschijn, welke laatste weer eene aanduiding van eene overlangsche splitsing vertoont. Vergr. 1500.

Fig. 4. Een iets verder gevorderd stadium. Een drietal lissen komen uit het synapsis-kluwen. Evenzoo twee gestrekte draden, die beiden eene aanduiding van eene lengtesplitsing vertoonen, terwijl de eene bovendien bij a geknikt is. Vergr. 1500.

Fig. 5. Eene lis en vier gestrekte draden komen uit het synapsis-kluwen te voorschijn. De twee draden links vertoonen eene buiging. Het bovenste paar heeft vrij duidelijk eene dubbelnatuur. Ook bij de overigen ziet men aanduidingen van lengte-splitsingen. Vergr. 2250.

Fig. 6. Een volgend stadium. Thans zijn 3 lissen en 3 gestrekte draden buiten het synapsis-kluwen gekomen. De laatsten toonen aanduidingen van lengte-splitsingen, de twee links hebben elk een knik. Vergr. 2250.

Fig. 7. Nog later stadium. Drie lissen met vrije uiteinden (1, 2 en 3$)$ en drie nog gesloten lissen ( 4,5 en 6$)$. Vergr. 2250.

Fig. 8 en 9. Stadiën, nog iets verder gevorderd. Op één na zijn thans alle lissen geopend. De draden worden korter en dikker. Vergr. 2250.

Fig. 10. De gepaarde chromosomen worden steeds korter en dikker. Hier en daar zijn splijtingen zichtbaar. De beide uiteinden, die het meest naar links komen, zijn duidelijk dubbel. Het bovenste hiervan vertoont bij * een opvallenden knik. De 6 andere uiteinden der chromosomenparen liggen nog in het synapsis-kluwen, dat nu zeer in omvang afgenomen is. Vergr. 2250. 
Fig. 11. Een later stadium kort vóór de diakinese. Meerdere der paren zijn in de lengte gespleten. Bij $a$ en $b$ ziet men duidelijk dubbele uiteinden. Een oprallende knik bij *. Vergr. 2250.

Fig. 12. Een dergelijk stadium. Bij $a$ en $b$ frati gespleten niteinden. De overige paren vertoonen eveneens in het midden eene overlangsche splitsing. Evenzoo de beide onderste, die door hunne V-vormige gedaante in het oog loopen. Vergr. 2250.

Fig. 13. Onmiddellijk vóór de diakinese. Men ziet, hoe de paren met hun eéne uiteinde in het midden zijn blijven samenhangen. Onderatan hebben een $\mathrm{O}$-vormig en een V-vormig paar zich los gemaakt. De overige paren zijn eveneens volgens hun lengte gesplitst. Het bovenste heeft bij $a$ een knik. Vergr. 2250 .

Fig. 14. Diakinese. Vịjf paren hebben een V-vorm, één $(a)$ is een ring. Vergr. 2250.

Fig. 15. Diakinese. Vier paren hebben een V-vorm, één paar ligt achter den nucleolus. Het onderste paar toont twee dicht naast elkar liggende korte chromosomen. Vergr. 2250.

Fig. 16. Diakinese. Links een ring. Het par beneden den uncleolus en dat rechts boven hebben een V-vorm. Bij * ziet men een parr, waarvan de beide chromosomen elkander geheel hebben losgelaten. Verder twee kleine paren. Verg. 2250.

Fig. 17 en 18. Eveneens diakinese-stadiën. Bij * in Fig. 18 liggen twee paren loodrecht op elkaar. Vergr. 2250. 


$$
\begin{aligned}
& \text { is ans; } \\
& \left\{\begin{array}{l}
x=1 \\
\therefore<1
\end{array}\right.
\end{aligned}
$$

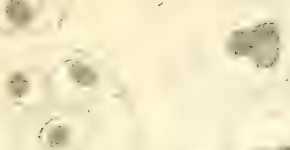

$$
\begin{aligned}
& \text { i) } \\
& 121^{\circ}
\end{aligned}
$$
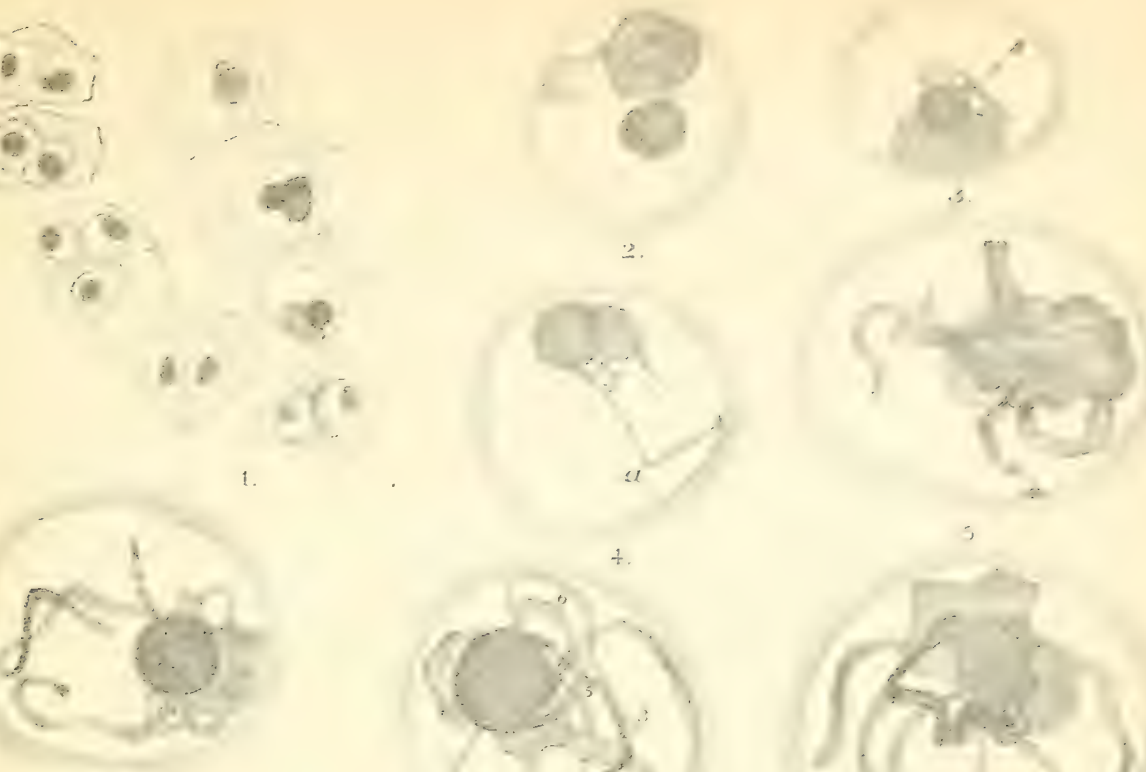

ij.

$+\cdots$
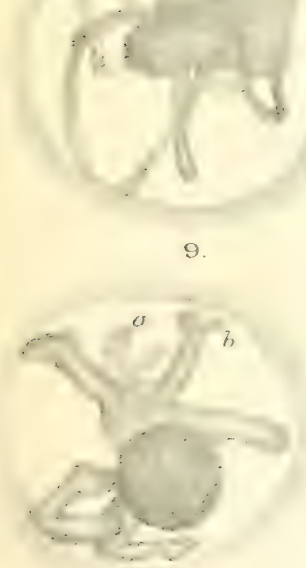

12.
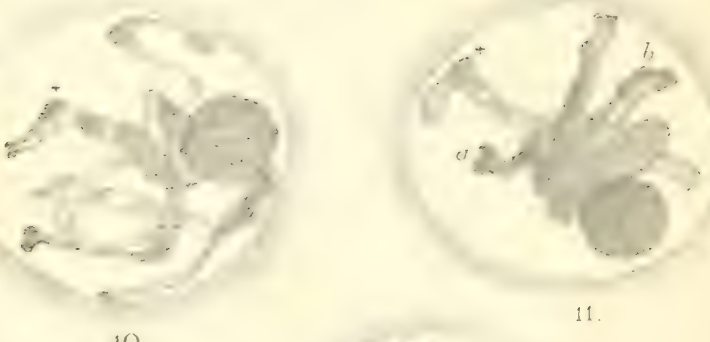

$$
10 .
$$
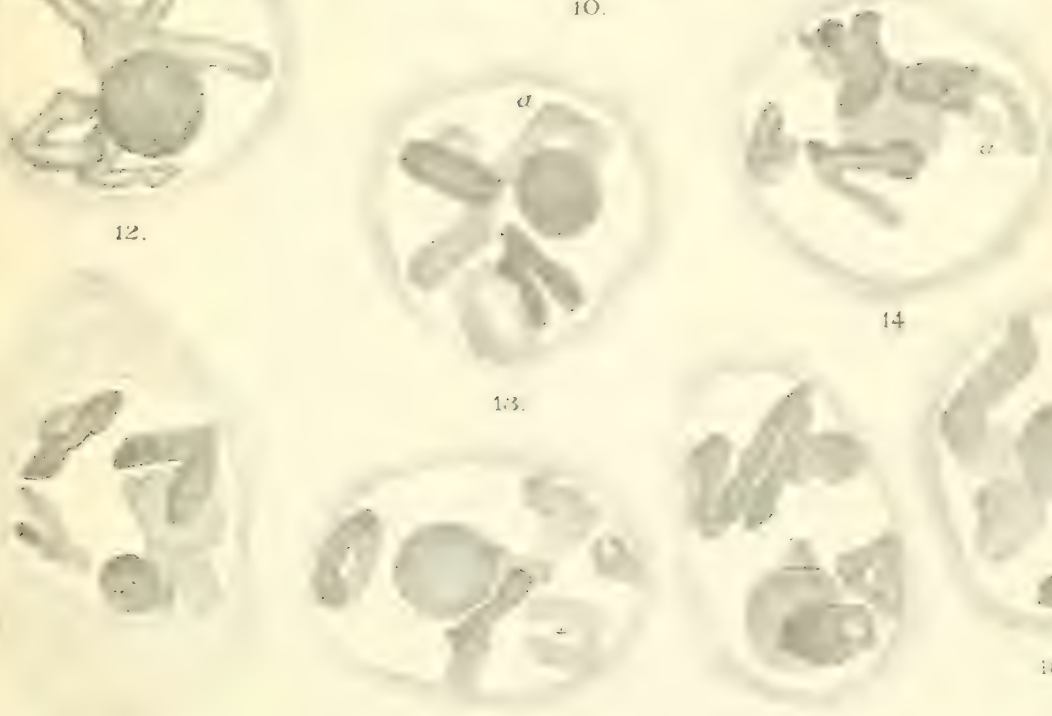

$i t$;
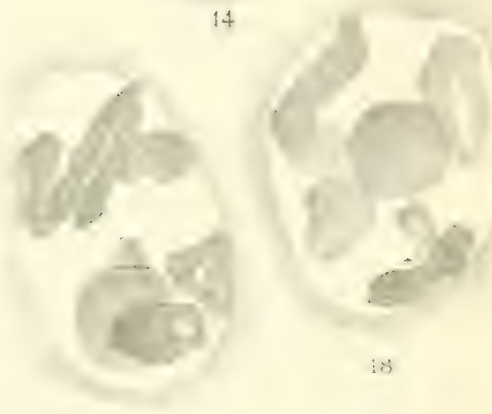



\section{PLAAT III.}

Fig. 1-23 hebben betrekking op het ontstaan van het pollen.

Fig. 1. Onmiddellijk na de diakinese. Men ziet, dat de paren der chromosomen nog hun $\mathrm{V}$ en $\mathrm{O}$-vormen bewaard hebben. Tusschen de paren duidelijke vacuolen. Vergr. 2250.

Fig. 2. Kernplaat van de heterotype deeling Vergr. 2250.

Fig. 3. Twee chromosomen-paren uit eene dergelijke kernplaat overlangs gezien. Bij het van terzijde geziene paar grijpen de bundels der trekdraden ongeveer in het midden aan, waardoor de uiteengaande chromosomen eenigszins een V-vorm aannemen. Vergr. 2250.

Fig. 4 en 5 toonen elk een paar chromosomen, dat aan het meest naar de binnenzijde van de spoel gekeerde einde door de trekdraden wordt aangegrepen en uiteengetrokken. Vergr. 2250.

Fig. 6. De chromosomen op weg naar de polen. Aan den æquator zijn thans belangrijk minder in de lengte loopende draden waar te nemen, dan bij de polen. Niet onwaarschijnlijk is het, dat het meest linksche paar chromosomen, evenals in Fig. 3, in het midden is aangegrepen. Van eene lengtesplitsing der chromosomen is nog weinig te zien. Vergr. 1500.

Fig. 7. De chromosomen zijn bij de polen der spoel aangekomen. Zij vertoonen thans allen min of meer duidelijk, dat zij volgens de lengte gesplitst zijn. De beide met $a$ gemerkte hebben een V-vorm en zijn waarschijnlijk in hun midden door de spoeldraden aangegrepen. Vergr. 1500.

Fig. 8. Ontstaan der dochterkernen. Tusschen de chromosomen. paren treden vacuolen op. Het paar bij * toont thans duidelijk, dat het eene dubbele $\mathrm{V}$ is. In het praeparaat lagen in het oog loopend veel extranucleaire nucleolen. Vergr. 2250.

Fig. 9 en 10. Dochterkernen van de heterotype deeling, in Fig. 9 van terzijde geteekend, zoodat men een deel van den phragmoplast ziet; in Fig. 10 van de pool gezien. In beide figuren zijn 6 paren waarneembaar. Vergr. 2250 .

Fig. 11 en 12. De kernmembraan verdwijnt. Men krijgt den indruk, dat tusschen de paren van chromosomen zich vacuolen bevinden. Deze paren toonen min of meer duidelijk hun dubbelnatuur. In Fig. 11 is de kern van de pool gezien. In Fig. 12 van de zijde. Vergr. 2250.

Fig. 13. Moedercel tijdens de homoiotype deeling. In het midden ligt een goed ontwikkelde phragmoplast. Daarboven eene kernplaat, omgeren door groote vacuolen. Er onder eene spoel, in de lengte gezien. Bij de laatste valt op, dat sommige chromosomen hun niet aan de trekdraden bevestigde einden het eerst uiteen laten gaan. Vergr. 1500. 
Fig. 14. Kernplaat van de homoiotype deeling. Twee chromosomen schijnen een V-vorm te hebben. Misschien komt dit tenminste bij een ran deze twee daardoor tot stand, dat de twee overlangsche helften, die in de figuur boven elkaar liggen, een weinig ten opzichte van elkander verschoven zijn. Tusschen de chromosomen is het veld donkerder tengerolge van de aanwezigheid der spoel. Aanduidingen van spoeldraden zijn in het midden waarneembaar. Vergi. 2250.

Fig. 15 en 16. Spoelen van de homoiotype deeling, in de lengte gezien. De chromosomen vertoonen twee overlangsche helften en zijn meest met het naar binnen gekeerde einde aan de trekdraden bevestigd. In Fig. 16 bij * een chromosoom, dat in het midden wordt aangegrepen. Vergr. 2250.

Fig. 17. Deze figuru toont, hoe ook hier de chromosomen zoowel aan hun einde, als in hun midden door de trekdraden kunnen worden aangegrepen. Vergr. 2250.

Fig. 18. Spoel van de tweede deeling. De chromosomen wijken naar de polen uiteen. Het hoogst liggende (in de figuur het donkerst geteekende) chromosoom is in zijn midden door de trekdraden aangegrepen. Dit is vooral in de onderste helft der figuur duidelijk. Tusschen de twee uiteengaande complexen van chromosomen zijn thans weer veel minder draden zichtbaar, dan dichter bij de polen. Het valt op, dat deze spoel, met dezelfde vergrooting $(2250 \quad X)$ geteekend als de spoelen van Fig. 15 en 16, veel langer is dan deze, gerekend van pool tot pool.

Fig. 19. Einde van de tweede deeling. De chromosomen zijn bij de polen aangekomen. In het meest linksche groepje telt men er op het eerste gezicht 7. Dit wordt daardoor veroorzaakt, dat het chromosoom bij a een V-vorm heeft. De phragmoplast, die in Fig. 13 nog zichtbaar was, is thans geheel verdwenen. Vergr. 1500.

Fig. 20. Ontstaan van de dochterkernen der tweede deeling. Tusschen de chromosomen treden weer vacuolen op. Vergr. 2250.

Fig. 21 en 22. Verdere stadiën van dochterkernen. In Fig. 21 neemt men nog compacte ophoopingen van chromatine waar, in Fig. 22 zijn deze gestrekt, en treden er vacuolen in op. Vergr. 2250.

Fig. 23. Een der 4 cellen eener pollentetrade. De vacuolisatie der chromosomen is nog niet van beteekenis. Vergr. 2250.

Fig. 24. Rij van dubbelkernige cellen uit een wortel. Van onderen naar boven: 2 dicht tegen elkaar liggende kernen, eene dubbele spoel, twee met elkaar versmeltende kernen en eene veel grootere blijkbaar dubbele kern. Vergr. \pm 500 . 
Plaat III.
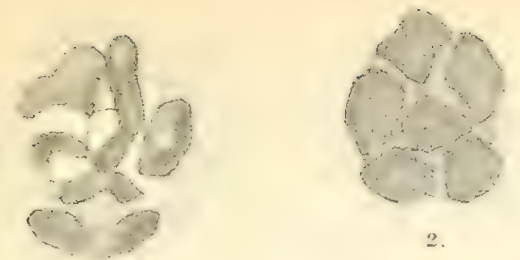

2 .
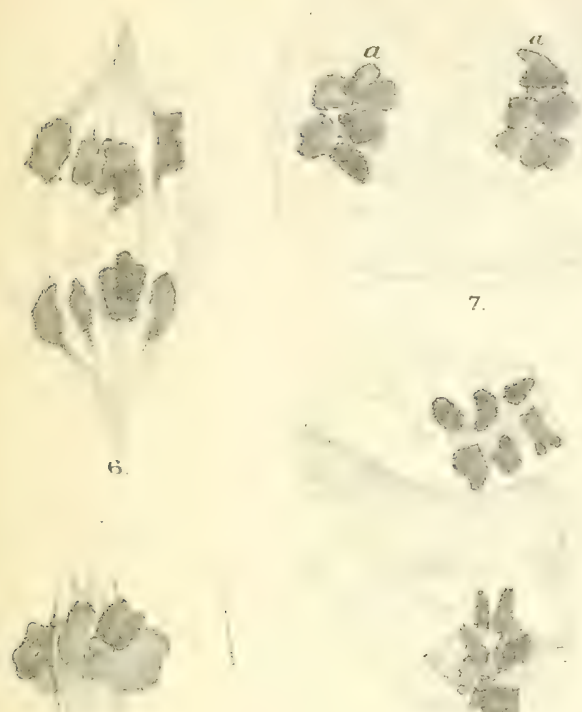

15.

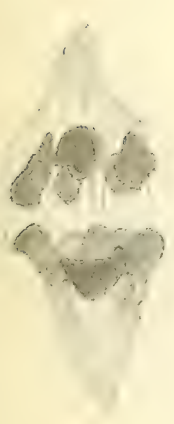

18.

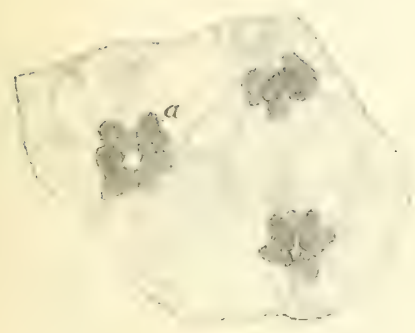

19.

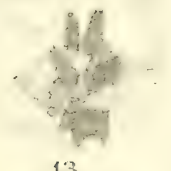

13.
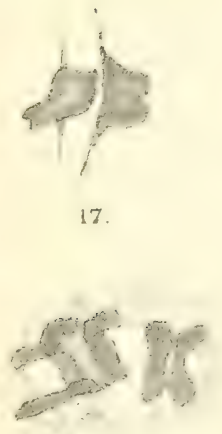

20.

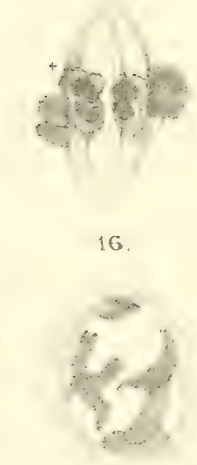

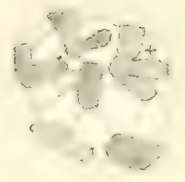

8.

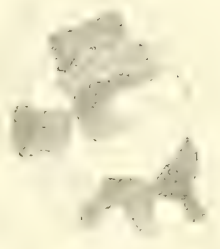

11.

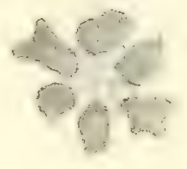

14 .

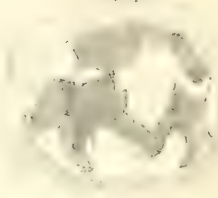

9

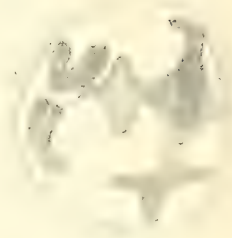

10)

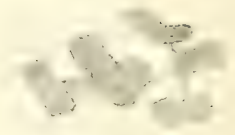

12
21.
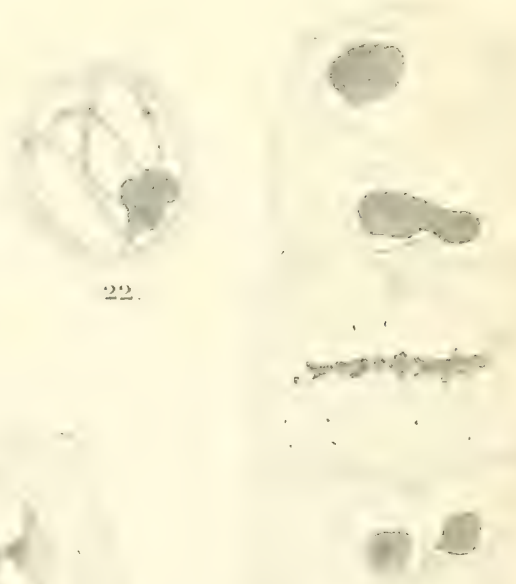

24. 






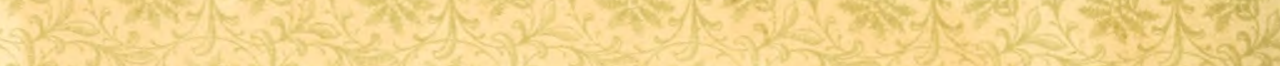

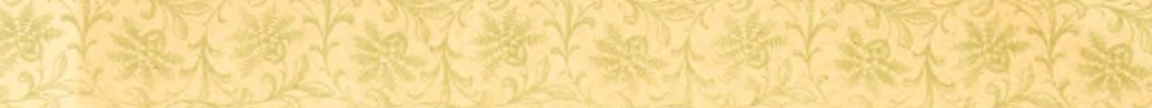
(2) W.
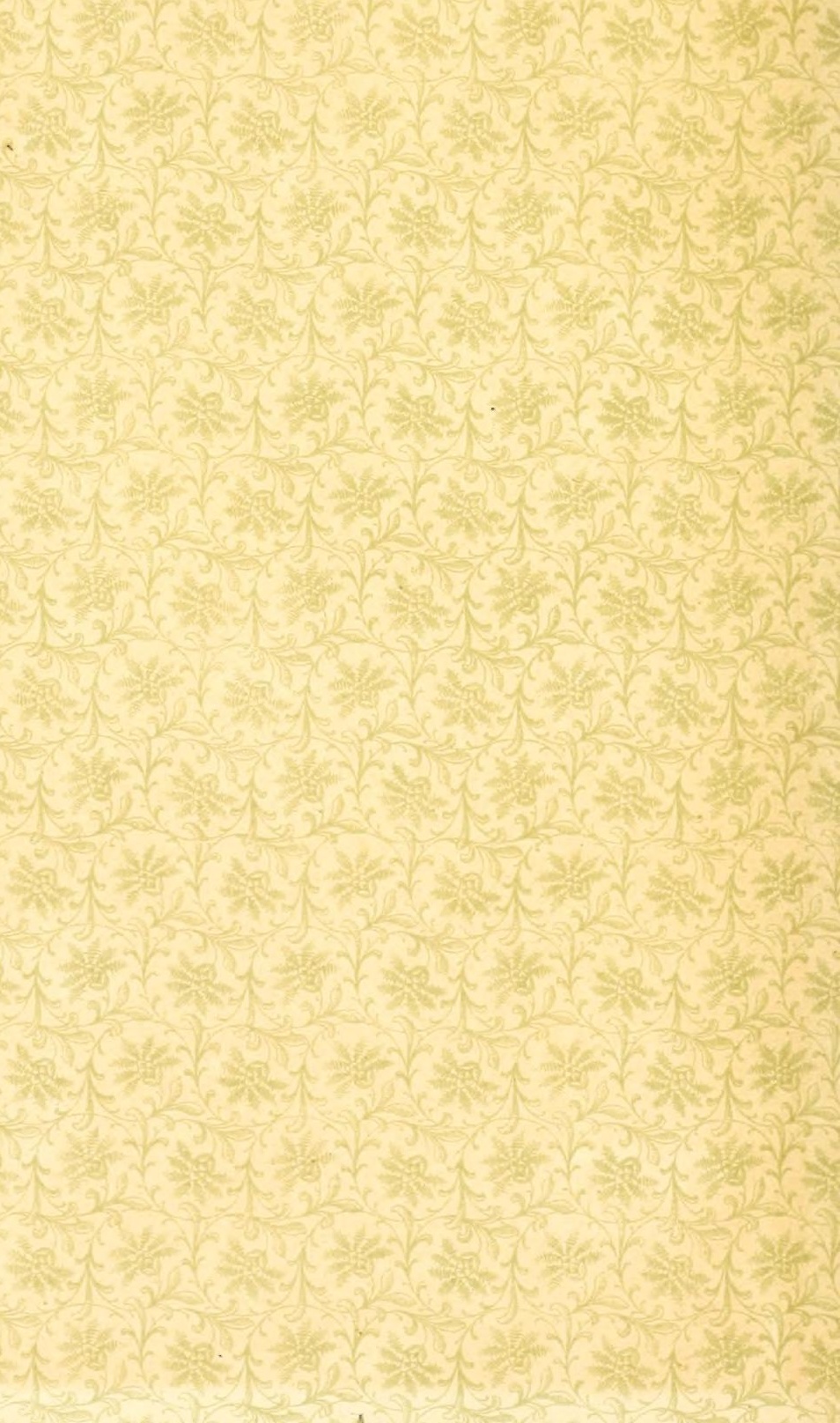
New York Botanical Garden Library

QL 95 .S6 S8

gen

Stomps, Theodoor Ja/Kerndeeling en synap |||||||||||||||||||||||||||||||||||||||||||||||||||||||||||||||||||||||||||||||||||||||||||||

35185000662492 
